\title{
A Precise Chronology of Middle to Late Holocene Bison Exploitation in the Far Southern Great Plains
}

Jon C. Lohse

Coastal Environments, Inc. and Gault School for Archaeological Research

Brendan J. Culleton

Department of Anthropology, The Pennsylvania State University

Stephen L. Black

Department of Anthropology, Texas State University

Douglas J. Kennett

Department of Anthropology, The Pennsylvania State University

Follow this and additional works at: https://scholarworks.sfasu.edu/ita

Part of the American Material Culture Commons, Archaeological Anthropology Commons, Environmental Studies Commons, Other American Studies Commons, Other Arts and Humanities Commons, Other History of Art, Architecture, and Archaeology Commons, and the United States History Commons

Tell us how this article helped you.

This Article is brought to you for free and open access by the Center for Regional Heritage Research at SFA ScholarWorks. It has been accepted for inclusion in Index of Texas Archaeology: Open Access Gray Literature from the Lone Star State by an authorized editor of SFA ScholarWorks. For more information, please contact cdsscholarworks@sfasu.edu. 


\section{A Precise Chronology of Middle to Late Holocene Bison Exploitation in the Far Southern Great Plains}

\section{Licensing Statement}

Reproduction, posting, transmission, or other distribution or use of the Journal volume, individual article or any portion of the material therein, in any medium, is permitted strictly for personal, non-commercial purposes via a personal-use exemption under a Creative Commons license granted by JTAH.org, Inc. This license exemption requires, as a condition of its granted permission, proper credit be attributed to JTAH.org as copyright holder (e.g., Journal of Texas Archeology and History.org @ 2014). No part of this publication may be reproduced, posted, transmitted, or otherwise utilized or distributed in any form by any means or method for commercial purposes without the express written consent of the Publisher.

Inquiries should be addressed to JTAH Publisher, Suite 307, Box 361, 5114 Balcones Woods Drive, Austin, Texas, 78759.

The Journal of Texas Archeology and History.org is an organization dedicated to furthering research, education and public outreach in the fields of archeology and history concerning Texas and its bordering states of Louisiana, Arkansas, Oklahoma, New Mexico and Northern Mexico; a region we call the "Texas Borderlands." The J.T.A.H. is collaborating with the Index of Texas Archaeology and S.F.A.S.U. to distribute their publication library to the general public via free and open-access channels. Visit www.JTAH.org to submit an article. 


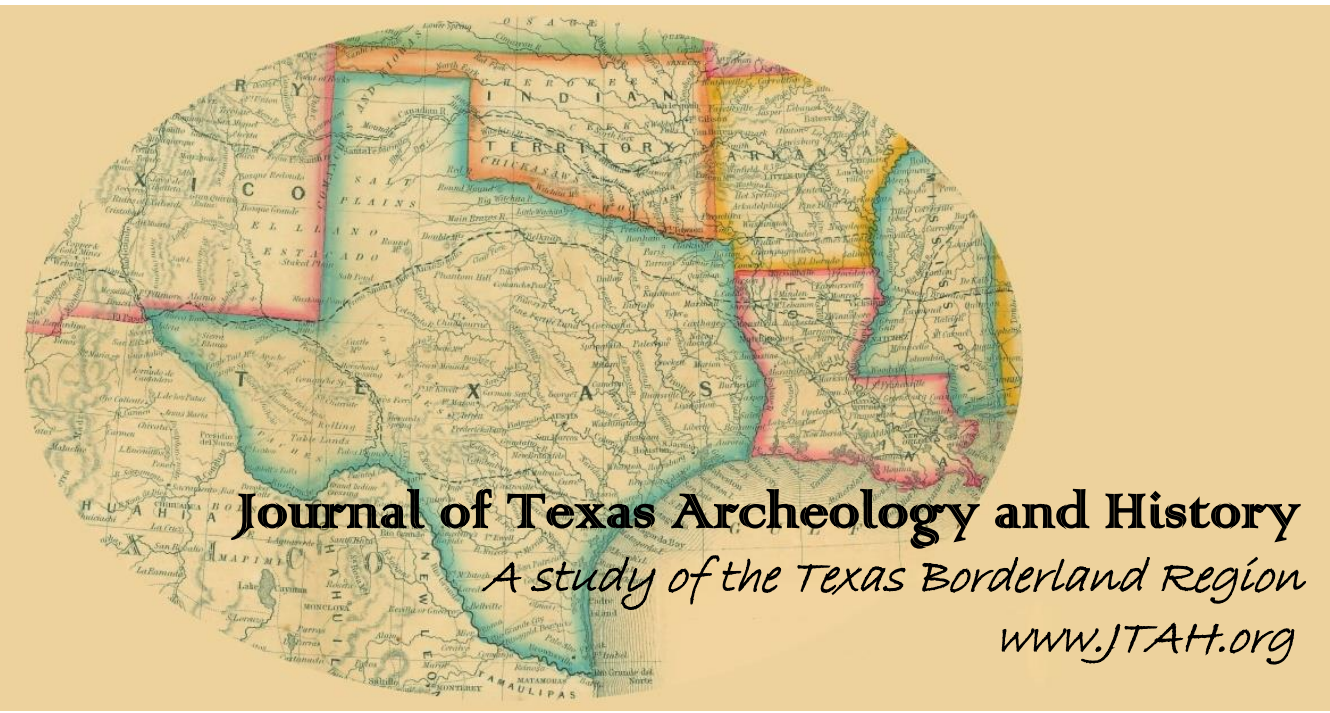

\section{Article Title: A PRECISE CHRONOLOGY of MIDDLE to LATE HOLOCENE BISON EXPLOITATION in the FAR SOUTHERN GREAT PLAINS Author(s): $\quad$ Jon C. Lohse, Brendan J. Culleton, Stephen L. Black, and Douglas J. Kennett}

Original Source: J.T.A.H. Volume 1 (2014), Article 5, pp. 94 -126; online 04 December 2014

Recommended Citation: Lohse, Jon C., Brendan J. Culleton, Stephen L. Black, and Douglas J. Kennett; "A Precise Chronology of Middle to Late Holocene Bison Exploitation in the Far Southern Great Plains", (2014), Journal of Texas Archeology and History Volume 1 (2014), pp. 94-126.

Copyright $(\subseteq 2014$ by Journal of Texas Archeology and History.org, Inc. All rights reserved. Online/Digital publication: ISSN 2334-1874

The online, digital and print versions of the publication "Journal of Texas Archeology and History" are published by Journal of Texas Archeology and History.org, Inc., a Texas nonprofit IRC Section 501(c)(3) corporation.

Reproduction, posting, transmission, or other distribution or use of the Journal volume, individual article or any portion of the material therein, in any medium, is permitted strictly for personal, non-commercial purposes via a personal-use exemption under a Creative Commons license granted by JTAH.org, Inc. This license exemption requires, as a condition of its granted permission, proper credit be attributed to JTAH.org as copyright holder (e.g., Journal of Texas Archeology and History.org (C) 2014). No part of this publication may be reproduced, posted, transmitted, or otherwise utilized or distributed in any form by any means or method for commercial purposes without the express written consent of the Publisher. Inquiries should be addressed to JTAH Publisher, Suite 307, Box 361, 5114 Balcones Woods Drive, Austin, Texas, 78759.

The Journal of Texas Archeology and History.org is an organization dedicated to furthering research, education and public outreach in the fields of archeology and history concerning Texas and its bordering states of Louisiana, Arkansas, Oklahoma, New Mexico and Northern Mexico; a region we call the "Texas Borderlands." The J.T.A.H. is collaborating with the Index of Texas Archaeology and S.F.A.S.U. to distribute their publication library to the general public via free and open-access channels. Visit www.JTAH.org to submit an article. 


\title{
A PRECISE CHRONOLOGY OF MIDDLE TO LATE HOLOCENE BISON EXPLOITATION IN THE FAR SOUTHERN GREAT PLAINS
}

\author{
Jon C. Lohse, Brendan J. Culleton, Stephen L. Black, and Douglas J. Kennett
}

\begin{abstract}
In regions on the margins of the Great Plains grasslands, documenting the intermittent history of bison exploitation has presented challenges to archeologists. Chronologies based on archeological associations have long been useful in regional research, but can be imprecise and of inadequate resolution for constructing precise sequences of prehistoric events. Here, we present a record of directly dated bison from archeological contexts spanning the last 6000 years on the very southern extent of the Great Plains. This study includes 61 specimens from archeological contexts that were dated by XAD purified AMS radiocarbon, with reported errors of only 15-20 14C years for most dates. The resulting record of bison exploitation for this area defines four main periods (Calf Creek, Late Archaic 1 and 2, and early Toyah) during which bison were exploited. Several dates also indicate an early historic presence of bison; this period may represent a late facet of the Toyah horizon. This study adds significant chronological resolution to the regional record of bison in parts of Texas and begins to help correlate cultural chronologies with important climatic data. It also points to the research value of obtaining additional directly dated bison samples from temporally and geographically diverse archeological contexts in our study area and beyond.
\end{abstract}

\section{INTRODUCTION}

The North American genus Bison was among the very top-ranked resources available to huntergatherers up to and even following the arrival of European explorers. Millennia of bison hunting on the Plains are documented from Early Paleoindian times onward (Bamforth 1988, 2011; Bement and Buehler 1994; Bozell et al. 2011; Carlson and Bement 2013; Cooper 2008; Frison 1991, 1998, 2004; Guthrie 1980). In Late Prehistoric times, agriculturalists in the American Southwest and Mississippi River drainages to the east often hunted bison or traded for their products, bringing them into frequent contact with Plains tribes (Creel 1991; Spielmann 1991; Speth 2004; Speth and Newlander 2012; Vehik 1990, 2002). Bison exploitation, for meat and other uses, has played a significant role in shaping prehistoric and early historic economies across the Plains. As a top-ranked food resource, the

\footnotetext{
JOURNAL OF TEXAS ARCHEOLOGY AND HISTORY

VOLUME 1:94-126

THE ONLINE PUbliCATION JOURNAL OF TEXAS ARCHEOLOGY AND HISTORY (ISSN 2334-1874)

IS PUBLISHED BY JOURNAL OF TEXAS ARCHEOLOGY AND HISTORY.ORG.

COPYRIGHT (C) 2014 JOURNAL OF TEXAS ARCHEOLOGY AND HistORY.ORG. All RIGHTS RESERVED.
} 
presence of bison would have had tremendously important implications for prehistoric subsistence practices, mobility, the organization of labor, and other social characteristics.

While bison were present almost continuously in the cool, predominantly $\mathrm{C}_{3}$ grasslands of the Northern Plains, only occasionally in the Middle to Late Holocene periods did they extend into other environments characterized by mixed grasslands or other habitats. These areas include parts of the Great Basin (Grayson 2006), northern Mexico (List et al. 2007), and the southern limits of the Plains that include Central and coastal Texas (Baugh 1986; Dillehay 1974; Huebner 1991; Lynott 1979; Mauldin et al. 2012; Ricklis 1992). Understanding precisely when bison were present in regions located around the periphery of the Plains is important not only for our general knowledge regarding bison ecology, climate, and environmental change in North America, but also for providing insights into human responses during these periods.

In this study, we present and evaluate AMS radiocarbon data for $61 \mathrm{XAD}$ purified samples of bison bone recovered from archeological contexts at seven sites located in Central and South Texas. The culture history of these areas shares much with Plains traditions to the north during some time intervals, while maintaining their own distinct patterns during others (Collins 1995, 2004; Hester 2004; Lohse et al. 2014a). Precisely defining periods when bison were present in these areas has been a challenge, largely as a result of the traditional reliance on dating bison by association with other archeological remains. Our approach involves directly dating bison from archeological contexts as a way to avoid the imprecision that can result from dating by association. The resulting chronology defines four primary periods of prehistoric bison exploitation beginning around $6000 \mathrm{cal} \mathrm{B.P.} \mathrm{and} \mathrm{also}$ indicates an early Historic use by North American Indians. Earlier periods of bison presence remain to be worked out for these areas, ideally using a similar methodology to the one we discuss herein. This precise chronology not only clarifies regional prehistoric subsistence and related technological practices, but can also help researchers correlate cultural developments with environmental or paleoclimatic data that may be associated with periods of rapid cultural change.

\section{DATING BISON IN THE STUDY AREA AND THE PRESENT SAMPLE}

Beginning with Dillehay (1974), many investigators have examined the issue of bison presence in the region (Baugh 1986; Collins 1995; Huebner 1991; Lynott 1979; Mauldin et al. 2012; Quigg 1997; Ricklis 1992). These studies commonly evaluate the presence of bison at a regional scale based on archeological components that are themselves dated by radiocarbon or by cross-dating using associated time-marker artifacts (Table 1). Typically, bison presence is modeled as a series of long periods of presence or absence, the beginnings and endings of which are imprecisely dated.

In contrast to regional models, single-site records (such as the one at Wilson-Leonard, 41WM235 [Collins 1998]), where bison were not present for certain intervals when they appear elsewhere, exemplify the limitations of site-specific studies. A given site's stratigraphy may be compressed or mixed, affecting an analysts' ability to precisely reconstruct periods of bison exploitation. This condition most directly and adversely affects bison chronologies that rely on archeological association. In other cases, a single site's occupation history may not include periods during which 
bison were present nearby. For example, Bonfire Rockshelter (41VV218) offers a fascinating record of bison hunting during certain periods in the Lower Pecos of southwest Texas, including Late Archaic,

Table 1. Some models of bison presence and visibility in the study region.

\begin{tabular}{|c|c|c|c|c|}
\hline Southern Plains (Dillehay 1974) & \multicolumn{2}{|c|}{ Central Texas (Mauldin et al. 2012) } & \multicolumn{2}{|c|}{$\begin{array}{l}\text { Wilson-Leonard (Sichler et al. } \\
\text { 2011, from data by Baker 1998) }\end{array}$} \\
\hline $\begin{array}{l}\text { Presence Period } 3 \\
800 \text { B.P. }\end{array}$ & $\begin{array}{l}473.8 \text { avg. } \\
\text { NISPI } \\
\text { component }\end{array}$ & 700-400 B.P. & $\begin{array}{l}18 \mathrm{NISP} / \\
\text { component }\end{array}$ & $1700-4200$ B.P. \\
\hline $\begin{array}{l}\text { Absence Period } 2 \\
1500-800 \text { B.P. }\end{array}$ & $\begin{array}{l}2.9 \text { avg. } \\
\text { NISPI } \\
\text { component }\end{array}$ & $1250-700$ B.P. & $\begin{array}{l}1 \mathrm{NISP} / \\
\text { component }\end{array}$ & 4200-5200 B.P. \\
\hline $\begin{array}{l}\text { Presence Period } 2 \\
4500-1500 \text { B.P. }\end{array}$ & $\begin{array}{l}7.3 \text { avg. } \\
\text { NISPI } \\
\text { component }\end{array}$ & 1600-1250 B.P. & $\begin{array}{l}59 \mathrm{NISP} / \\
\text { component }\end{array}$ & $\begin{array}{l}>11,000- \\
9000 \text { B.P. }\end{array}$ \\
\hline $\begin{array}{l}\text { Absence Period } 1 \\
\text { ca. } 7000 \text { B.P.-4500 B.P. }\end{array}$ & $\begin{array}{l}316.9 \text { avg. } \\
\text { NISP/ } \\
\text { component }\end{array}$ & 2500-1600 B.P. & & \\
\hline $\begin{array}{l}\text { Presence Period } 1 \\
>11,000-7000 \text { B.P. }\end{array}$ & $\begin{array}{l}6.0 \text { avg. } \\
\text { NISP/ } \\
\text { component }\end{array}$ & 4450-2500 B.P. & & \\
\hline
\end{tabular}

Folsom, and perhaps Clovis times (Bement 1986; Dibble and Lorrain 1968). However, this record does not include bison remains from the Calf Creek horizon, material traces of which are reported in nearby Eagle Cave (41VV167, Ross 1965) as well as from Jeff Davis and Brewster counties some 150 $\mathrm{km}$ to the west (Gray 2013; Walter 2013), indicating that the record at Bonfire Rockshelter does not completely reflect the character of regional bison histories.

Our study draws from several sites geographically dispersed across a wide area. We do not imply that our study area corresponds with any particular archeological region(s). Indeed, the size of what might be called a "bison catchment" that is represented by this study is not precisely known. However, previous research indicates the potential size of prehistoric bison ranges. Carlson and Bement (2013) estimate mobility ranges from ca. $100 \mathrm{~km}$ (Clovis times) to up to ca. $600 \mathrm{~km}$ (late Folsom times) in diameter in an area centered on Oklahoma that includes southern Kansas, the Texas Panhandle, and eastern New Mexico. Widga et al. (2010) reconstruct inter-annual movements of $\leq 500 \mathrm{~km}$ over a period of about 4-5 years for Early/Middle Holocene (ca. 7-8.5 ka) bison in the eastern Great Plains of eastern Nebraska, South Dakota, western Iowa, and southwest Wisconsin. An area of ca. $600 \mathrm{~km}$ in diameter easily encompasses all of the sites from which samples in this study were taken (Figure 1). 


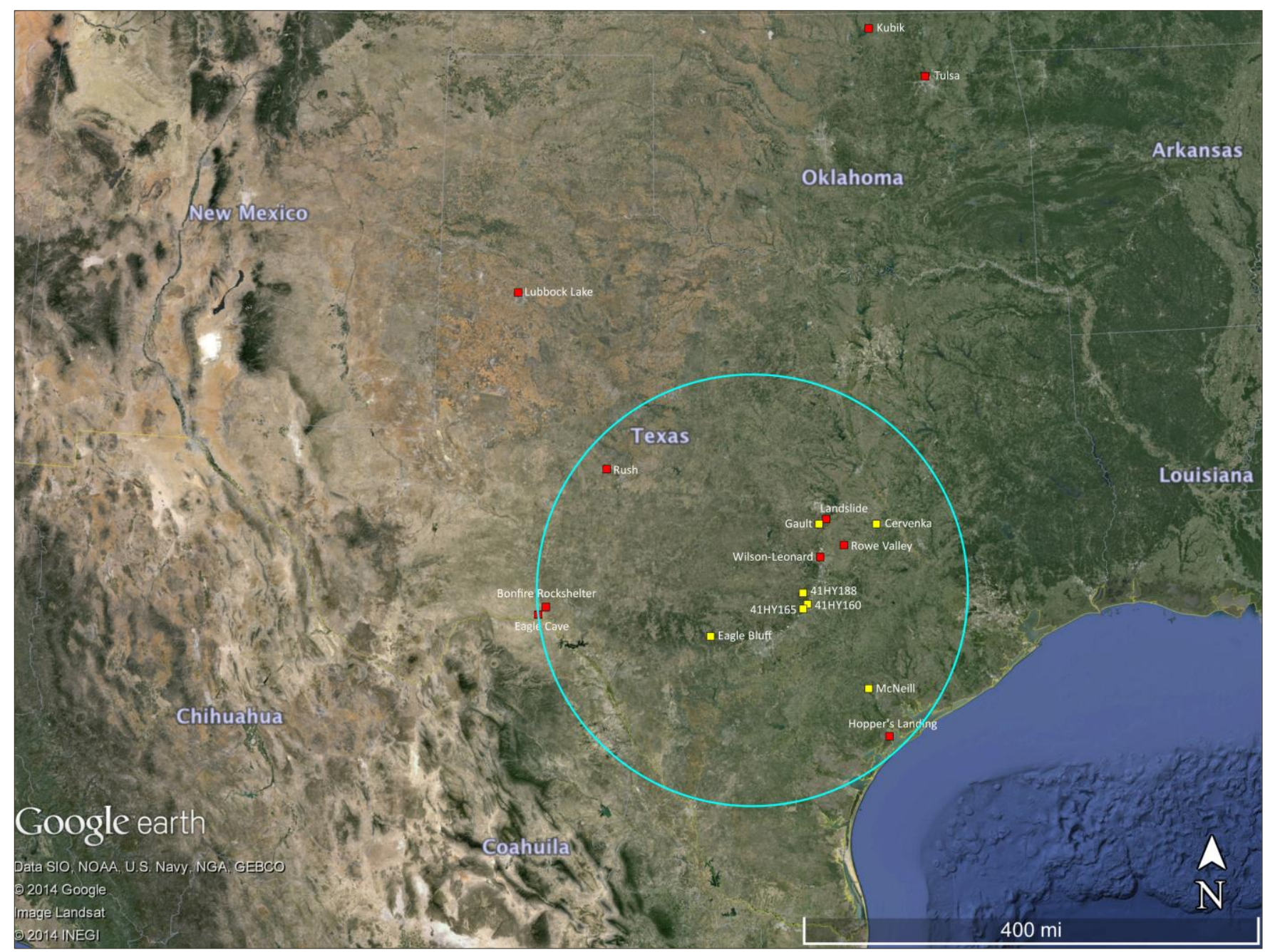

Figure $1.600 \mathrm{~km}$ diameter study area illustrating the distance prehistoric herds may have travelled if they maintained mobility patterns comparable to those reconstructed elsewhere in North America. Sites dated in this study are shown in yellow; other sites discussed in the text are shown in red.

The presence of bison in the archeological record is, first, the result of environmental process and, second, a reflection of hunter-gatherer behavior. The key to building reliable bison chronologies, therefore, involves the number of temporal components that are sampled (i.e., selected for direct dating) within a given bison range. We propose that bison histories can be accurately reconstructed using sites with intermittent occupation records, so long as each period of bison presence in the total study area is well represented in at least one site's deposits. Alternatively, large portions of a bison chronology can also be compiled from a small number of sites, assuming that each period during which bison were present on the landscape is represented in site components and has been sampled. In this approach, compiling a large number of assays (i.e., high sample density) helps to ensure that all or most intervals of bison presence within the region are included. A weakness of this approach is that the geographic limits of bison territorial ranges will likely remain poorly known until sampling densities clearly define the geographic limits for each temporal period of bison presence. 
Minimally, the patterns presented below are valid for the sites and time periods included in our study. Although we consider it likely that these patterns reflect larger-scale trends across a much broader area, only future sampling following the methods we employ here can precisely identify the extent of territorial ranges that are associated with the temporal periods in our chronology. For example, reports of bison presence throughout the Holocene at Lubbock Lake (41LU1) (Johnson 1987; Johnson and Holiday 1987) seem to suggest that the chronology presented here does not extend to the Texas Panhandle (see Figure 1).

Our sample draws heavily from $41 \mathrm{HY} 160$ and HY165, sites that are associated with Spring Lake, formed by impounded freshwater springs at the headwaters of the San Marcos River in Hays County, Texas. Based on temporally diagnostic artifacts and radiocarbon data (Figure 2), the Spring Lake sites exhibit a nearly continuous record of occupation from Clovis to historical periods (Lohse 2013). These sites are important to this study because their essentially continuous sequence means that remains of bison, as a top-ranked food resource, should be expected to occur whenever bison were present on the surrounding landscape. The occupation record of these sites distinguishes them from others, like Bonfire, with intermittent histories of site use. Controlled excavations at Spring Lake have generally not extended below the Early Archaic archeological deposits and intensive archeological sampling has only been conducted to ca. 6000 cal B.P. depths (Lohse et al. 2013), which represents the temporal limit of our study. Another site (41HY188) is less than $5 \mathrm{~km}$ from Spring Lake and evidences Late Prehistoric and Late Archaic occupation associated with bison (Bettis 1996). Two other specimens come from Eagle Bluff (41ME147) in Medina County (Hester 2010, 2011), one from Gault (41BL323) in Bell County, two from McNeill (41VT141) in Victoria County, and one from Cervenka (41WM267) in Williamson County (Peter et al. 1982). Each site contains deep, multi-component deposits in stratified alluvial settings, and is interpreted as a long-term encampment, making it unlikely that bison were killed at any of these locations. Rather, butchered remains were likely transported from kill sites back to these occupation areas for additional processing.

Assemblages from 41HY160, 41HY165, and 41HY188 were examined for bison remains suitable for dating. Virtually all specimens identified as bison were fragmented to the point that age and sex could not be consistently estimated. Therefore, no age and sex data are presented for the bison from any of our study sites. All cataloged contexts were evaluated, and specimens were selected from as many different proveniences by depth and site area as possible. Through this approach, every time period characterized by bison presence (and sampled by controlled excavation) had an equal chance of being identified. As noted, high sampling density was a priority in order to better model periods of bison presence. Samples were included from the other sites based on accessibility, preservation, and the limits of available funding.

Selected specimens were pre-treated for collagen extraction and purification using a XAD process modified from earlier work by Stafford that isolates individual amino acid chains (Stafford et al. 1988, 1991). Two modern approaches to removing exogenous carbon from bone collagen samples have been developed and refined over the last two decades: modified Longin (1971) extraction with ultrafiltration (Brown et al. 1988) and XAD-purification (Stafford et al. 1988, 1991). Ultrafiltration works 


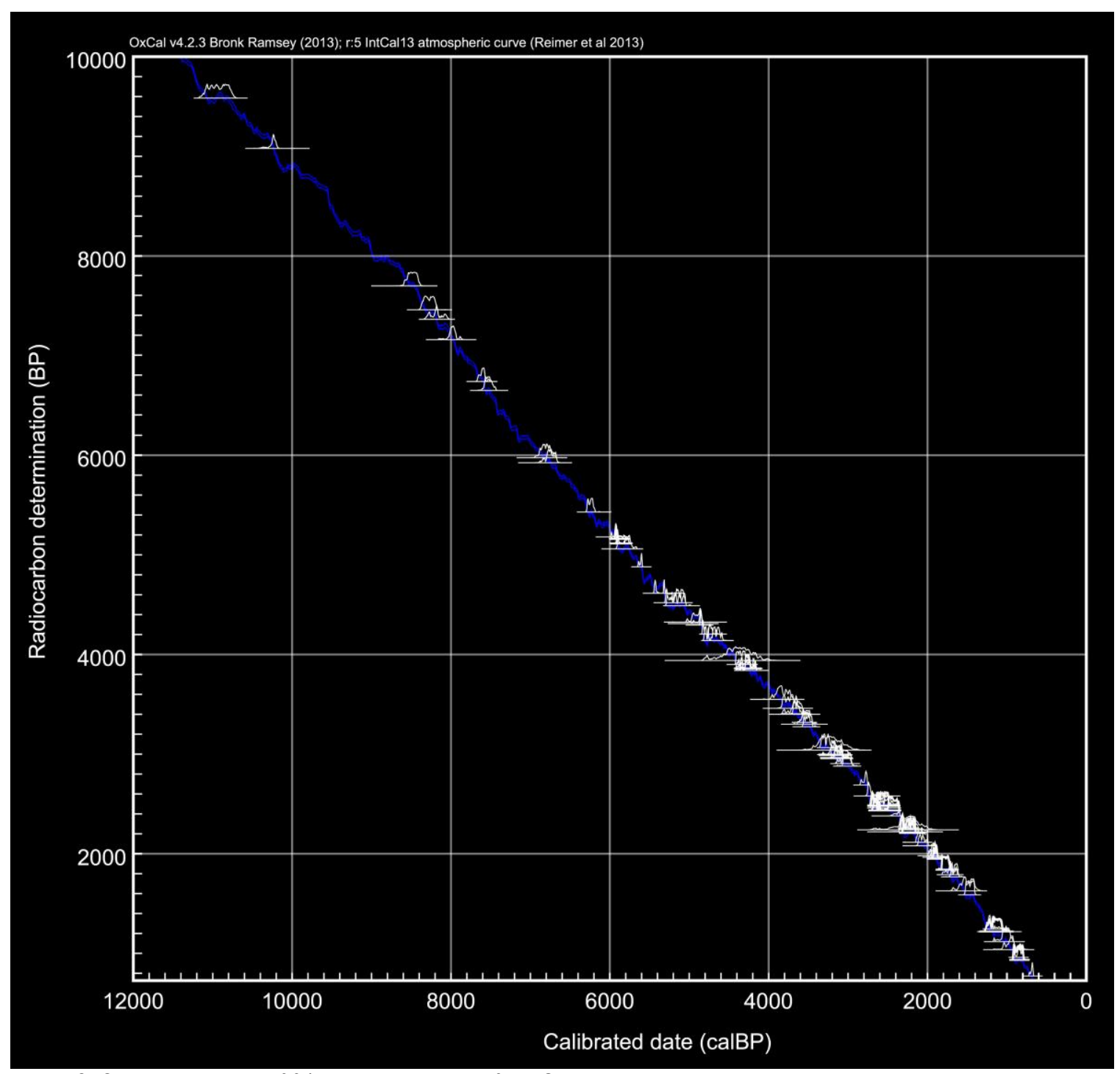

Figure 2. Calibrated results of 94 radiocarbon dates from Spring Lake, showing the nearly continuous occupation record extending to just after $6000 \mathrm{cal} \mathrm{B.P.} \mathrm{and} \mathrm{the} \mathrm{subsequent} \mathrm{decline} \mathrm{of} \mathrm{dates} \mathrm{that} \mathrm{reflects} \mathrm{the} \mathrm{limits} \mathrm{of} \mathrm{controlled}$ excavations. Two older dates not from archeological contexts are excluded (redrawn from Lohse 2013:Figure 4-1).

by retaining long-chain gelatin molecules (typically larger than $30 \mathrm{kDa}$ ) and filtering out smaller, potentially degraded gelatin molecules and contaminating humates smaller than $30 \mathrm{kDa}$. The lower yield of datable gelatin that results from ultrafiltration can limit its use on very poorly preserved bone (e.g., in cases where little or no long-chain protein survives), but smaller chains may be recoverable. One advantage of the modified XAD method is that all of the crude gelatin extracted from the bone can be processed for stable isotope measurement and AMS ${ }^{14} \mathrm{C}$ dating. Another advantage is that exogenous carbons that can remain following ultrafiltration treatments are removed, ensuring greater accuracy of measured ages.

Stafford et al. (1988, 1991) argued that gelatinization as described by Longin (1971) is not adequate to disassociate all humic and fulvic acids bound to collagen and that contaminants may cross-bind with smaller degraded collagen chains to create longer chains that would be retained in the 
filter. Our approach to eliminating these contaminants is to break the collagen down to individual amino acids by hydrolysis in concentrated $(6 \mathrm{~N}) \mathrm{HCl}$, thereby releasing humic and fulvic acids into solution. Polar contaminants are then removed from the solution by chromatography using a column filled with XAD resin. The method used in this study is adapted from that of Stafford et al. (1988, 1991). Similar methods of XAD amino acid dating has been used to reliably reevaluate pre-Clovis, Clovis, and other Early Paleoindian chronologies in North America (Waters and Stafford 2007, 2014; Waters et al. 2011) by dating osseous remains and artifacts clearly associated with Terminal Pleistocene cultural deposits.

At the Human Paleoecology and Isotope Geochemistry Lab at Pennsylvania State University, each sample was cleaned and sectioned with disposable Dremel cut-off wheels and then demineralized in $0.5 \mathrm{~N} \mathrm{HCl}$ for two to three days at $5^{\circ} \mathrm{C}$. The demineralized collagen pseudomorph was then gelatinized at $60^{\circ} \mathrm{C}$ in $4-5 \mathrm{~mL} 0.01 \mathrm{~N} \mathrm{HCl}$ for eight to 10 hours. Sample gelatin was pipetted into a pre-cleaned $10 \mathrm{ml}$ disposable syringe with an attached $0.45 \mu \mathrm{m}$ Millex Durapore PVDF filter (precleaned with methanol and Nanopure $\mathrm{H}_{2} \mathrm{O}$ ) and driven into a thick-walled culture tube. The filtered solution was then lyophilized and percent gelatinization and yield determined by weight. The sample gelatin was then hydrolyzed in $2 \mathrm{~mL} 6 \mathrm{~N} \mathrm{HCl}$ for 22 hours at $110^{\circ} \mathrm{C}$. Supelco ENVI-Chrom ${ }^{\circledR}$ SPE (Solid Phase Extraction; Sigma-Aldrich) columns were prepped with two washes of methanol $(2 \mathrm{~mL})$ and rinsed with $10 \mathrm{ml}$ DI $\mathrm{H}_{2} \mathrm{O}$. With a $0.45 \mu \mathrm{m}$ Millex Durapore filter attached, the SPE Column was equilibrated with $50 \mathrm{~mL} 6 \mathrm{~N} \mathrm{HCl}$ and the washings discarded. $2 \mathrm{~mL}$ collagen hydrolyzate as $\mathrm{HCl}$ was pipetted onto the SPE column and driven with an additional $10 \mathrm{ml} 6 \mathrm{~N} \mathrm{HCl}$ dropwise with the syringe into a $20 \mathrm{~mm}$ culture tube. The hydrolyzate was finally dried into a viscous syrup by passing UHP $\mathrm{N}_{2}$ gas over the sample heated at $50^{\circ} \mathrm{C}$ for ca. $12 \mathrm{hr}$.

Stable carbon and nitrogen isotope measurements, $\% \mathrm{C}$ and $\% \mathrm{~N}$, were determined on amino acid hydrolyzate samples $(\sim 0.7 \mathrm{mg})$ at the University of California, Irvine Keck Carbon Cycle Accelerator Mass Spectrometer facility, on a Fisons NA1500NC elemental analyzer/Finnigan Delta Plus isotope ratio mass spectrometer with a precision of $<0.1 \%$ for $\delta^{13} \mathrm{C}$ and $\delta^{15} \mathrm{~N}$. Only samples with atomic C:N ratios between 3.0-3.4, indicative of good collagen preservation (Ambrose and Norr 1992; DeNiro 1985; van Klinken 1999), were submitted for AMS ${ }^{14} \mathrm{C}$ dating and are included in this study. AMS samples ( 4.0 mg) were combusted for three hours at $900^{\circ} \mathrm{C}$ in vacuum-sealed quartz tubes with $\mathrm{CuO}$ wire and $\mathrm{Ag}$ wire to produce sample $\mathrm{CO}_{2}$. Sample $\mathrm{CO}_{2}$ was reduced to graphite at $550^{\circ} \mathrm{C}$ using $\mathrm{H}_{2}$ and a Fe catalyst, with reaction water drawn off with $\mathrm{C}-9 \mathrm{Mg}\left(\mathrm{ClO}_{4}\right)_{2}$ (Santos et al. 2004). Graphite samples were pressed into targets in Al boats and loaded on a target wheel with OX-1 (oxalic acid) standards, known age bone secondaries, and a ${ }^{14} \mathrm{C}$-free Pleistocene whale blank. The ${ }^{14} \mathrm{C}$ measurements were made on a modified National Electronics Corporation compact spectrometer with a $0.5 \mathrm{MV}$ accelerator (NEC 1.5SDH-1). Analytical error in the 2-3\%o range was achieved, which for the current study translates to standard deviations in the range of $\pm 15-20{ }^{14} \mathrm{C}$ years. Radiocarbon ages were $\delta^{13} \mathrm{C}$-corrected for mass dependent fractionation with $\delta^{13} \mathrm{C}$ values measured on the AMS (Stuiver and Polach 1977), and compared with samples of Pleistocene whale bone (background, $>48 \mathrm{k}$ ${ }^{14} \mathrm{C}$ B.P.), a ca. $12400{ }^{14} \mathrm{C}$ B.P. horse bone, ca. $1840{ }^{14} \mathrm{C}$ B.P. bison bone, late A.D. 1800 s cow bone, and OX-1 oxalic acid standards for calibration. All dates are calibrated with the IntCal13 curve (Reimer et al. 2013) using OxCal 4.2 (Bronk Ramsey 2010) and are presented in calibrated years 
before present (cal B.P.). In order not to imply undue precision, all results are rounded to the nearest five-year interval (Table 2).

Regarding data presented in Table 2, a small number $(n=4)$ of statistical outliers are present in our sample. Statistical outliers in each temporal period that contain five or more specimens are those samples with $\delta^{13} \mathrm{C}$ values more than 1.5 times the interquartile range below the first quartile or higher than the third quartile (Fenner 2007). These specimens are identified in Table 2 as having very low (negative) $\delta^{13} \mathrm{C}$ values. No statistical outliers were identified based on $\delta^{15} \mathrm{~N}$. Outliers such as these are often reported from archeological bison herds such as at Folsom (Meltzer 2006:Table 6.19) and JonesMiller (Tieszen et al. 1997), and elsewhere we have speculated that these may represent sexually mature bulls that had migrated into the study area from elsewhere (Lohse et al. 2014b). We are not aware of any research to date that has focused specifically on explaining or interpreting these outliers, but they are not uncommon in archeological studies of prehistoric bison isotopes.

We define periods of bison presence (also called temporal groups) based on the clustering of calibrated ${ }^{14} \mathrm{C}$ dates. In addition to standard calibration we calculate the duration of each period as the Difference of the earliest and latest samples in each group using $\mathrm{OxCal}$, and summarize the range with means of those dates. Because we are unlikely to have directly dated the earliest or latest bison for any of our temporal groups, future dating is likely to affect the span of one or more groups. OxCal's Sum command is used to visually summarize the distributions within each group of dates, but this is merely a heuristic rather than an analytical tool. Because of the high density of samples taken from 41HY160, $41 \mathrm{HY} 165$, and $41 \mathrm{HY} 188$, it is possible that the same animals from these sites may have been dated more than once. If such cases exist, however, they do not adversely affect our chronology, since assays are only used to indicate when bison were hunted, and are not used to reconstruct herd population dynamics. Evaluating the individual carbon and nitrogen isotope measurements for each sample (shown in Table 2) shows that no two samples returned the same radiocarbon and isotope values. This suggests that any duplicate measurement of the same animal is minimal.

As noted, one result of our analytical approach is that the resulting chronology has greater precision than temporal models based on traditional (i.e., non-pretreated) bone dating and/or those relying on archeological association. While such methods have long provided useful information about the general timing of events, they are not well suited for addressing the precise timing of prehistoric events or when researchers are interested in documenting periods of rapid or punctuated cultural adaptations. Precise chronologies, sometimes also called "short chronologies" (e.g., Denham et al. 2012; Kennett et al. 2011, 2014; Tzedakis 2003; Wilmshurst et al. 2011) because they cover shorter spans of time than "long chronologies" of the same phenomena, are based on careful selection and AMS ${ }^{14} \mathrm{C}$ measurement of short-lived, pretreated species that minimizes the difference between the dated and target events. This approach can be differentiated from simple "dating," which might include no particular strategy to help ensure greater chronometric precision, and "high precision" dating, which we see as efforts that begin with the kind of sample selection and treatment we use but that also employ appropriate statistical manipulation, such as Bayesian statistics, of constrained data 
Table 2. XAD-purified bison dates by lab number and provenience and stable isotope measurements discussed in this study. All dates are calibrated using IntCal13 (Reimer et al. 2013) (from Lohse et al. 2014b:Table 2).

\begin{tabular}{|c|c|c|c|c|c|c|}
\hline $\begin{array}{l}\text { UCIAMS } \\
\text { Number }\end{array}$ & Provenience & $\begin{array}{l}\text { C:N } \\
\text { Ratio }\end{array}$ & ${ }^{14} \mathrm{C}$ Age & $\begin{array}{l}\text { delta }^{15} \\
\mathrm{~N}\end{array}$ & delta ${ }^{13} \mathrm{C}$ & $2 \sigma$ calibrated range (cal BP) \\
\hline 29246 & $\begin{array}{l}\text { 41VT141, Area B, } \\
\text { N376, E826, level } 10\end{array}$ & 3.26 & $190 \pm 20$ & 5.5 & -7.8 & $290-265$ (19.6\%), 215-145 (52.9\%) \\
\hline 81005 & $\begin{array}{l}\text { 41HY165, Unit 2, } \\
\text { level } 7\end{array}$ & 3.16 & $215 \pm 15$ & 8.6 & -11.1 & $300-275(34.5 \%), 175-150(50.2 \%)$ \\
\hline 81002 & $\begin{array}{l}\text { 41HY165, Unit 2, } \\
\text { level } 2\end{array}$ & 3.14 & $250 \pm 15$ & 8.9 & -9.4 & $310-285$ (86.7\%), 165-155 (8.7\%) \\
\hline 87921 & $\begin{array}{l}\text { 41HY160, Unit } 4 \text {, } \\
\text { level } 3\end{array}$ & 3.16 & $275 \pm 15$ & 6.9 & -14.3 & $425-395$ (27.6\%), 320-290 (67.8\%) \\
\hline 106463 & $\begin{array}{l}\text { 41HY160, Unit } 3 \text {, } \\
\text { level } 5\end{array}$ & 3.03 & $515 \pm 15$ & 6.72 & -11.51 & $545-515$ \\
\hline 129247 & $\begin{array}{l}\text { 41VT141, Area 5(B), } \\
\text { N376, E826, Feature } \\
\text { 2, level } 10\end{array}$ & 3.26 & $515 \pm 15$ & 5.5 & -7.8 & $545-515$ \\
\hline 81003 & $\begin{array}{l}\text { 41HY165, Unit } 2 \text {, } \\
\text { level } 3\end{array}$ & 3.14 & $520 \pm 15$ & 5.3 & -9.0 & $545-515$ \\
\hline 80131 & $\begin{array}{l}\text { 41HY165, Unit } 7 \text {, } \\
\text { level } 2\end{array}$ & 3.16 & $535 \pm 20$ & 6.2 & -9.8 & $625-605(11.8 \%), 555-515$ (83.6\%) \\
\hline 87940 & $\begin{array}{l}\text { 41HY188, Unit } 35 \\
\text { SE, level } 5\end{array}$ & 3.16 & $535 \pm 15$ & 5.9 & -8.7 & $620-610(4.6 \%), 555-520(90.8 \%)$ \\
\hline 87929 & $\begin{array}{l}\text { 41HY188, Unit } 4 \text {, } \\
\text { level } 5\end{array}$ & 3.21 & $540 \pm 15$ & 5.7 & -9.4 & $620-610(10.0 \%), 555-520(85.4 \%)$ \\
\hline 87926 & $\begin{array}{l}\text { 41HY188, Unit } 1 \mathrm{NE} \text {, } \\
\text { level } 4\end{array}$ & 3.21 & $545 \pm 15$ & 6.4 & -10.8 & $625-605(17.5 \%), 560-525$ (77.9\%) \\
\hline 87932 & $\begin{array}{l}\text { 41HY188, Unit } 11 \\
\mathrm{NE} \text {, level } 4\end{array}$ & 3.17 & $545 \pm 15$ & 6.1 & -9.6 & $625-605(17.5 \%), 560-525$ (77.9\%) \\
\hline 87928 & $\begin{array}{l}\text { 41HY188, Unit } 4 \text { NW, } \\
\text { level } 3\end{array}$ & 3.19 & $545 \pm 15$ & 7.9 & -10.2 & $625-605(17.5 \%), 560-525$ (77.9\%) \\
\hline 87937 & $\begin{array}{l}\text { 41HY188, Unit } 22 \\
\text { SW, level } 11\end{array}$ & 3.19 & $545 \pm 15$ & 6.2 & -9.3 & $625-605(17.5 \%), 560-525$ (77.9\%) \\
\hline 81007 & $\begin{array}{l}\text { 41HY165, Unit 11, } \\
\text { level } 3\end{array}$ & 3.15 & $555 \pm 15$ & 6.7 & -8.9 & $630-600(34.7 \%), 560-530(60.7 \%)$ \\
\hline
\end{tabular}




\begin{tabular}{|c|c|c|c|c|c|c|}
\hline $\begin{array}{l}\text { UCIAMS } \\
\text { Number }\end{array}$ & Provenience & $\begin{array}{l}\text { C:N } \\
\text { Ratio }\end{array}$ & ${ }^{14} \mathrm{C}$ Age & $\begin{array}{l}\text { delta }{ }^{15} \\
\text { N }\end{array}$ & delta ${ }^{13} \mathrm{C}$ & $2 \sigma$ calibrated range (cal BP) \\
\hline 87930 & $\begin{array}{l}\text { 41HY188, Unit } 6 \mathrm{NE}, \\
\text { level } 8\end{array}$ & 3.15 & $555 \pm 15$ & 8.4 & -10.5 & $630-600(34.7 \%), 560-530(60.7 \%)$ \\
\hline 111183 & $\begin{array}{l}\text { 41ME147, N807 } \\
\text { E629, level } 3\end{array}$ & 3.07 & $560 \pm 15$ & 5.5 & -8.6 & $630-600(42.7 \%), 560-530(52.7 \%)$ \\
\hline 80133 & $\begin{array}{l}\text { 41HY165, Unit } 7 \text {, } \\
\text { level } 4\end{array}$ & 3.11 & $565 \pm 20$ & 4.6 & -7.3 & $635-595(51.8 \%), 560-530(43.6 \%)$ \\
\hline 87927 & $\begin{array}{l}\text { 41HY188, Unit } 2 \text { SW, } \\
\text { level } 3\end{array}$ & 3.19 & $570 \pm 15$ & 5.9 & -10.2 & $635-595$ (56.1\%), 560-535 (39.3\%) \\
\hline 80132 & $\begin{array}{l}\text { 41HY165, Unit 2, } \\
\text { level } 4\end{array}$ & 3.12 & $575 \pm 20$ & 5.1 & -9.6 & $640-590(61.2 \%), 565-535(34.2 \%)$ \\
\hline 87935 & $\begin{array}{l}\text { 41HY188, Unit } 22 \\
\text { SE, level } 5\end{array}$ & 3.21 & $580 \pm 15$ & 6.1 & -10.9 & $635-590(65.4 \%), 565-540(30.0 \%)$ \\
\hline 87931 & $\begin{array}{l}\text { 41HY188, Unit } 7 \\
\text { NW/NE, level } 3\end{array}$ & 3.19 & $580 \pm 15$ & 6.7 & -10.2 & $635-590(65.4 \%), 565-540(30.0 \%)$ \\
\hline 87936 & $\begin{array}{l}\text { 41HY188, Unit } 22 \\
\mathrm{NE} \text {, level } 10\end{array}$ & 3.23 & $585 \pm 15$ & 6.1 & -9.7 & $640-590(68.5 \%), 565-540(26.9 \%)$ \\
\hline 87933 & $\begin{array}{l}\text { 41HY188, Unit } 11 \\
\mathrm{NE} \text {, level } 5\end{array}$ & 3.21 & $595 \pm 15$ & 5.9 & -10.2 & $645-585(73.6 \%), 565-545(21.8 \%)$ \\
\hline 80134 & $\begin{array}{l}\text { 41HY165, Unit 11, } \\
\text { level } 7\end{array}$ & 3.12 & $2205 \pm 20$ & 6.6 & -8.5 & $2310-2150$ \\
\hline 80137 & $\begin{array}{l}\text { 41HY160, Unit 10, } \\
\text { level } 7\end{array}$ & 3.13 & $2210 \pm 20$ & 5.7 & -7.6 & $2310-2155$ \\
\hline 80135 & $\begin{array}{l}\text { 41HY160, Unit 13, } \\
\text { level } 5\end{array}$ & 3.12 & $2255 \pm 20$ & 5.5 & -8.4 & $\begin{array}{l}2345-2305(41.3 \%), 2245-2180 \\
(51.4 \%), 2170-2160(2.7 \%)\end{array}$ \\
\hline 87925 & $\begin{array}{l}\text { 41HY160, Unit } 23 \\
\text { SE, level } 10\end{array}$ & 3.19 & $2270 \pm 15$ & 5.2 & -8.6 & $\begin{array}{l}\text { 2345-2305 (73.1\%), 2235-2185 } \\
(22.3 \%)\end{array}$ \\
\hline 87922 & $\begin{array}{l}\text { 41HY160, Unit 4, } \\
\text { level } 8\end{array}$ & 3.26 & $2275 \pm 15$ & 5.0 & -9.3 & $\begin{array}{l}2350-2305(82.4 \%), 2230-2205 \\
(12.3 \%), 2195-2190(0.7 \%)\end{array}$ \\
\hline 106470 & $\begin{array}{l}\text { 41HY160, Unit } 3 \text {, } \\
\text { level } 14\end{array}$ & 3.04 & $2415 \pm 20$ & 7.4 & -14.5 & $\begin{array}{l}2680-2665(2.1 \%), 2655-2645 \\
(2.5 \%), 2490-2355(90.8 \%)\end{array}$ \\
\hline 87920 & $\begin{array}{l}\text { 41HY160, Unit } 1 \\
\text { level } 2\end{array}$ & 3.21 & $2460 \pm 15$ & 6.0 & -8.2 & $\begin{array}{l}2705-2630(41.5 \%), 2620-2560 \\
(20.3 \%), 2545-2430(32.8 \%), 2390- \\
2385(0.8 \%)\end{array}$ \\
\hline 81004 & $\begin{array}{l}\text { 41HY165, Unit } 3 \text {, } \\
\text { level } 8\end{array}$ & 3.29 & $2460 \pm 25$ & 5.1 & -9.0 & $\begin{array}{l}2705-2630(31.8 \%), 2620-2380 \\
(63.6 \%)\end{array}$ \\
\hline
\end{tabular}




\begin{tabular}{|c|c|c|c|c|c|c|}
\hline $\begin{array}{l}\text { UCIAMS } \\
\text { Number }\end{array}$ & Provenience & $\begin{array}{l}\text { C:N } \\
\text { Ratio }\end{array}$ & ${ }^{14} \mathrm{C}$ Age & $\begin{array}{l}\text { delta }{ }^{15} \\
\mathrm{~N}\end{array}$ & delta ${ }^{13} \mathrm{C}$ & $2 \sigma$ calibrated range (cal BP) \\
\hline 87938 & $\begin{array}{l}\text { 41HY188, Unit } 23 \\
\text { SE, level } 8\end{array}$ & 3.22 & $2470 \pm 15$ & 6.3 & -8.6 & $\begin{array}{l}2705-2630(37.9 \%), 2620-2465 \\
(57.5 \%)\end{array}$ \\
\hline 87923 & $\begin{array}{l}\text { 41HY160, Unit } 6 \\
\text { level } 10\end{array}$ & 3.20 & $2470 \pm 15$ & 5.6 & -8.9 & $\begin{array}{l}2705-2630(37.9 \%), 2620-2465 \\
(57.5 \%)\end{array}$ \\
\hline 81006 & $\begin{array}{l}\text { 41HY165, Unit } 3 \text {, } \\
\text { level } 6\end{array}$ & 3.18 & $2475 \pm 15$ & 5.9 & -8.1 & $2710-2485$ \\
\hline 106465 & $\begin{array}{l}\text { 41HY160, Unit } 3 \text {, } \\
\text { level } 6\end{array}$ & 3.05 & $2475 \pm 20$ & 5.3 & -8.05 & $2715-2465$ \\
\hline 87924 & $\begin{array}{l}\text { 41HY160, Unit } 6 \\
\text { level } 11\end{array}$ & 3.18 & $2480 \pm 15$ & 5.1 & -8.4 & $2710-2490$ \\
\hline 87934 & $\begin{array}{l}\text { 41HY188, Unit 20, } \\
\text { level } 12\end{array}$ & 3.21 & $2480 \pm 15$ & 5.6 & -8.4 & $2710-2490$ \\
\hline 106464 & $\begin{array}{l}\text { 41HY160, Unit } 3 \text {, } \\
\text { Level } 6\end{array}$ & 3.08 & $2480 \pm 15$ & 5.41 & -9.19 & $2710-2490$ \\
\hline 106471 & $\begin{array}{l}\text { 41HY160, Unit } 4, \\
\text { level } 7\end{array}$ & 3.07 & $2490 \pm 20$ & 6.57 & -9.25 & $\begin{array}{l}2720-2650(21.8 \%), 2645-2490 \\
(73.6 \%)\end{array}$ \\
\hline 80138 & $\begin{array}{l}\text { 41HY160, Unit 13, } \\
\text { level } 13\end{array}$ & 3.11 & $2955 \pm 20$ & 5.5 & -7.8 & $\begin{array}{l}3210-3200(1.1 \%), 3180-3060 \\
(93.0 \%), 3050-3040(1.2 \%)\end{array}$ \\
\hline 80130 & $\begin{array}{l}\text { 41HY165, Unit } 8 \\
\text { level } 11\end{array}$ & 3.15 & $2965 \pm 20$ & 5.1 & -8.4 & $\begin{array}{l}3210-3190(4.4 \%), 3185-3065 \\
(91.0 \%)\end{array}$ \\
\hline 80140 & $\begin{array}{l}\text { 41HY160, Unit 13, } \\
\text { level } 13\end{array}$ & 3.12 & $2985 \pm 20$ & 5.4 & -9.5 & $3225-3075$ \\
\hline 87939 & $\begin{array}{l}\text { 41HY188, Unit 25, } \\
\text { level } 14\end{array}$ & 3.24 & $2995 \pm 15$ & 5.2 & 9.3 & $\begin{array}{l}3230-3140(88.2 \%), 3130-3115 \\
(2.8 \%), 3095-3080(4.3 \%)\end{array}$ \\
\hline 80129 & $\begin{array}{l}\text { 41HY165, Unit } 3 \\
\text { level } 7\end{array}$ & 3.12 & $3000 \pm 20$ & 5.6 & -7.8 & $\begin{array}{l}3320-3310(1.7 \%), 3240-3140 \\
(85.4 \%), 3130-3110(3.8 \%), 3095- \\
3080(4.4 \%)\end{array}$ \\
\hline 106472 & $\begin{array}{l}\text { 41HY160, Unit } 4, \\
\text { level } 7\end{array}$ & 3.11 & $3000 \pm 20$ & 7.18 & -8.77 & $\begin{array}{l}3320-3310(1.7 \%), 3240-3140 \\
(85.4 \%), 3130-3110(3.8 \%), 3095- \\
3080(4.4 \%)\end{array}$ \\
\hline 129245 & $\begin{array}{l}\text { 41BL323, N1161, } \\
\text { E1081, 94.4-94.37 } \\
\text { elevation }\end{array}$ & 3.32 & $3000 \pm 15$ & 5.6 & -8.3 & $\begin{array}{l}3235-3140(91.6 \%), 3125-3115 \\
(1.3 \%), 3095-3080(2.5 \%)\end{array}$ \\
\hline 95718 & $\begin{array}{l}\text { 41HY165, Unit } 11 \\
\text { level } 10\end{array}$ & 3.24 & $3065 \pm 15$ & 4.9 & -20.0 & $3350-3225$ \\
\hline
\end{tabular}




\begin{tabular}{|c|c|c|c|c|c|c|}
\hline $\begin{array}{l}\text { UCIAMS } \\
\text { Number }\end{array}$ & Provenience & $\begin{array}{l}\text { C:N } \\
\text { Ratio }\end{array}$ & ${ }^{14} \mathrm{C}$ Age & $\begin{array}{l}\text { delta }^{15} \\
\text { N }\end{array}$ & delta ${ }^{13} \mathrm{C}$ & $2 \sigma$ calibrated range (cal BP) \\
\hline 80999 & $\begin{array}{l}\text { 41HY160, Unit } 9 \text {, } \\
\text { level } 14\end{array}$ & $\begin{array}{l}\text { Too } \\
\text { small }\end{array}$ & $5060 \pm 40$ & - & - & $5910-5715$ \\
\hline 95717 & $\begin{array}{l}\text { 41HY160, Unit 14, } \\
\text { level } 13\end{array}$ & 3.21 & $5110 \pm 15$ & 8.1 & -10.7 & $\begin{array}{l}5915-5885(47.2 \%), 5820-5760 \\
(48.2 \%)\end{array}$ \\
\hline 80139 & $\begin{array}{l}\text { 41HY160, Unit } 7 \\
\text { level } 14\end{array}$ & 3.14 & $5115 \pm 20$ & 6.8 & -9.8 & $\begin{array}{l}5920-5880(48.4 \%), 5825-5755 \\
(47.0 \%)\end{array}$ \\
\hline 80136 & $\begin{array}{l}\text { 41HY160, Unit } 7 \\
\text { level } 15\end{array}$ & 3.15 & $5120 \pm 20$ & 9.3 & -9.6 & $\begin{array}{l}5925-5885(56.4 \%), 5820-5760 \\
(39.0 \%)\end{array}$ \\
\hline 80998 & $\begin{array}{l}\text { 41HY160, Unit } 7 \\
\text { level } 14\end{array}$ & 3.13 & $5120 \pm 20$ & 8.5 & -10.5 & $\begin{array}{l}5925-3935(56.4 \%), 5820-5760 \\
(39.0 \%)\end{array}$ \\
\hline 129248 & $\begin{array}{l}\text { 41WM267, Area D, } \\
\text { E-6, level 120-121, } \\
\text { 93.3-93.2 elevation }\end{array}$ & 3.28 & $5135 \pm 20$ & 5.7 & -8.6 & $\begin{array}{l}5935-5890(81.4 \%), 5810-5765 \\
(14.0 \%)\end{array}$ \\
\hline 106473 & $\begin{array}{l}\text { 41HY160, Unit 13, } \\
\text { level } 13\end{array}$ & 3.14 & $5140 \pm 20$ & 9.38 & -11.9 & $\begin{array}{l}5935-5890(87.3 \%), 5805-5770 \\
(8.1 \%)\end{array}$ \\
\hline 106468 & $\begin{array}{l}\text { 41HY160, Unit } 3 \text {, } \\
\text { level } 14\end{array}$ & 3.11 & $5140 \pm 20$ & 7.43 & -19.0 & $\begin{array}{l}5935-5890(87.3 \%), 5805-5770 \\
(8.1 \%)\end{array}$ \\
\hline 106469 & $\begin{array}{l}\text { 41HY160, Unit } 3 \\
\text { level } 14\end{array}$ & 3.17 & $5145 \pm 20$ & 9.59 & -11.9 & $\begin{array}{l}5940-5890(91.3 \%), 5805-5795 \\
(1.8 \%), 5785-5770(2.3 \%)\end{array}$ \\
\hline 81000 & $\begin{array}{l}\text { 41HY160, Unit 16, } \\
\text { level } 13\end{array}$ & 3.25 & $5155 \pm 15$ & 8.7 & -11.1 & $5935-5900$ \\
\hline 81001 & $\begin{array}{l}\text { 41HY160, Unit 16, } \\
\text { level } 13\end{array}$ & 3.19 & $5165 \pm 15$ & 8.3 & -11.5 & $\begin{array}{l}5980-5980(1.8 \%), 5940-5905 \\
(93.6 \%)\end{array}$ \\
\hline 80997 & $\begin{array}{l}\text { 41HY160, Unit } 7 \\
\text { level } 9\end{array}$ & 3.12 & $5180 \pm 15$ & 8.5 & -9.4 & $\begin{array}{l}5990-5970(16.4 \%), 5945-5910 \\
(79.0 \%)\end{array}$ \\
\hline 111182 & $\begin{array}{l}\text { 41ME147, N802 } \\
\text { E631, level } 4\end{array}$ & 3.46 & $5205 \pm 20$ & 3.6 & -16.7 & $5990-5920$ \\
\hline
\end{tabular}

to construct or build chronological models characterized by greatly reduced age range probabilities. While this study focuses on precisely dating bison, we include an example of high-precision chronology, below, based on our work with the Calf Creek archeological component at Spring Lake.

\section{RADIOCARBON RESULTS}

Prehistoric bison exploitation is dated to four main periods in our study area, the first lasting from ca. 5955-5815 cal B.P.; the second and third involving two pulses between 3295-3130 cal B.P. and 
2700-2150 cal B.P. separated by a 400+ year hiatus from ca. 3130 to 2700 cal B.P.; and the fourth consisting of a short Late Prehistoric interval from 650 to $530 \mathrm{cal}$ B.P (Figure 3). Four historic period dates range from approximately $400-150 \mathrm{cal}$ B.P. This last interval is hard to date precisely because of variations in atmospheric radiocarbon concentration during this period. However, historic documents record widespread bison hunting across Texas and nearby regions (e.g., Speth 2004; Wade 2003), and this period is critical for understanding regional culture historical events for the preceding three or four centuries. The prehistoric periods include the widespread Calf Creek horizon, found across the Southern Plains (Thurmond and Wyckoff 1999); two different periods in the regional Late Archaic (termed Late Archaic Bison 1 and Late Archaic Bison 2, $\mathrm{LA}_{\mathrm{B}} 1$ and $\mathrm{LA}_{\mathrm{B}} 2$, to distinguish these bison periods from subdivisions in the regional chronology); and what appears to be an early facet of the Toyah phase or horizon (Kenmotsu and Boyd 2012).

Calf Creek ( $n=13)$

LAB1 $(n=8)$

$\operatorname{LAB2}(\mathrm{n}=16)$

Toyah $(n=20)$
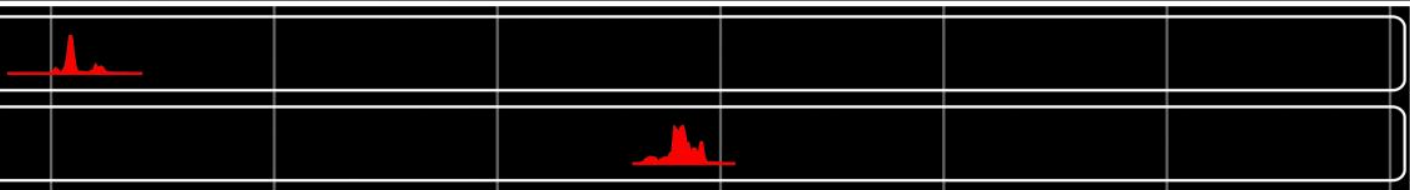

Historic $(n=4)$

Historic $(n=4)$
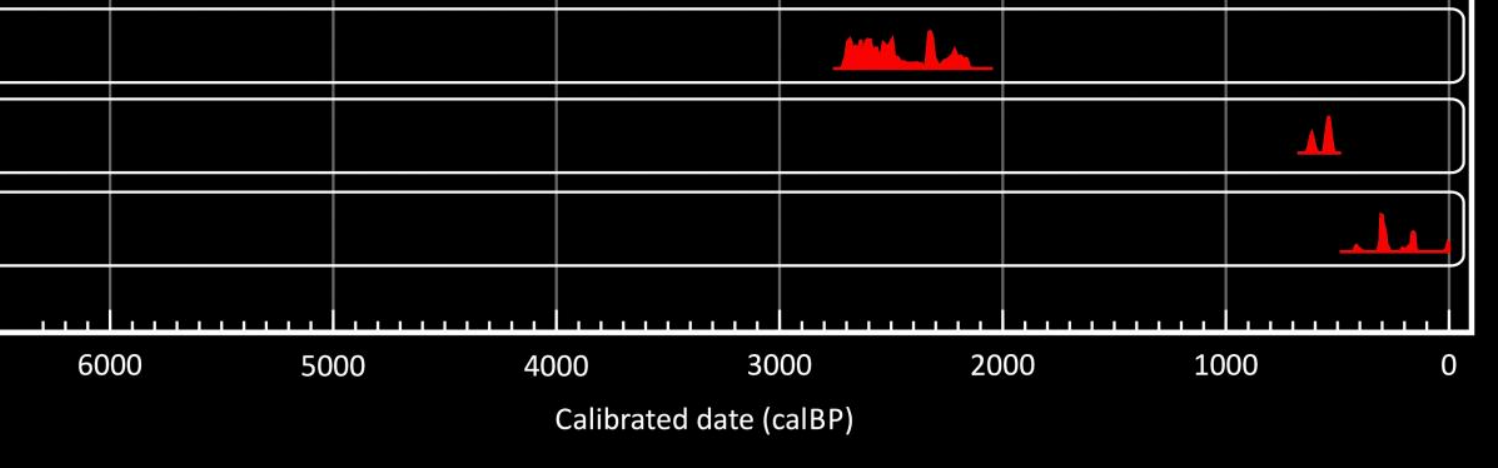

Figure 3. Summed probabilities for 61 XAD-purified AMS dates on bison bone from archeological contexts in Central and South Texas.

Calf Creek: ca. 5955-5815 cal B.P.

The earliest period of bison presence in our study is associated with the Calf Creek horizon. This period, which marks the end of the Early Archaic in Central Texas (Lohse et al. 2014a), is defined by the widespread occurrence of distinctive basally notched Bell and Andice points (Figure 4) often found in direct association with bison. Calf Creek materials are reported across Oklahoma (Bement et al. 2005; Duncan 1996; Neal 1999; Neal and Duncan 1998; Thurmond and Wyckoff 1999; Wyckoff 1994, 1995; Wyckoff et al. 2009); Central and South Texas, the Trans Pecos, and northern Tamaulipas (Calame et al. 2002; Collins 1994; Gray 2013; McReynolds 2002; Prewitt 1983; Ricklis 1988; Ross 1965; Sorrow et al. 1967; Walter 2013); western Arkansas (Dickson 1970); and into eastern New Mexico (Carmichael 1986). They are also present but less well documented in eastern Colorado, Missouri (O’Brien and Wood 1998), and Kansas (Stites 2006). Two Calf Creek points have recently been reported as far north as southern Utah (Wyckoff and Richens 2010). The brevity of this period has made it difficult to date these deposits with any precision. For example, this horizon is not 
represented in Dillehay's (1974) model for the Southern Plains (see Table 1), and is only poorly resolved at many sites (e.g., Wilson-Leonard). Stable carbon and nitrogen isotope data from samples in this study indicate that Calf Creek climates were among the coldest and perhaps driest experienced in the entire Holocene (Lohse et al. 2014b).

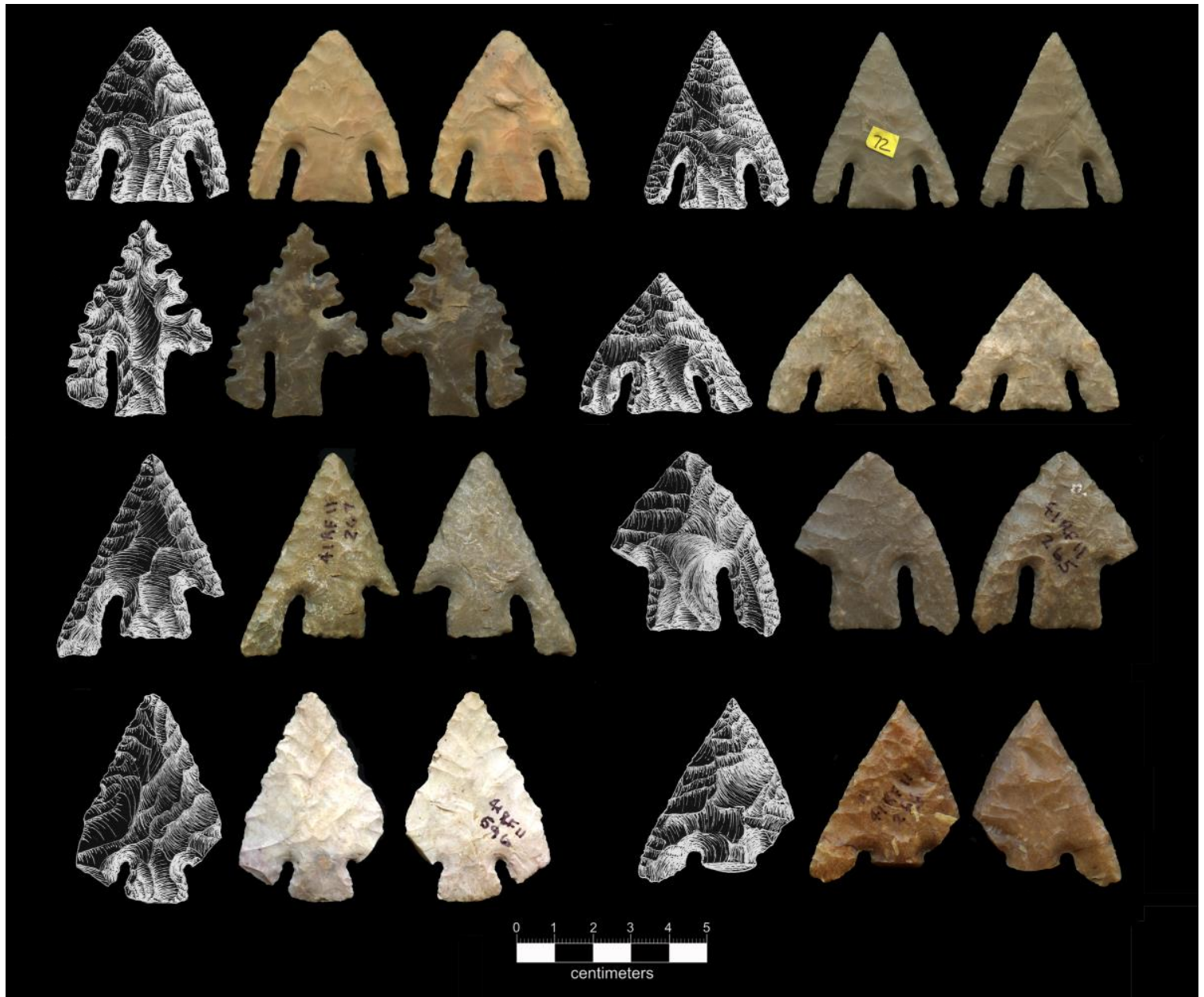

Figure 4. Examples of basally notched Calf Creek horizon points (Bell type). Top two rows are from Zapata County in South Texas (courtesy of Richard McReynolds). Bottom two rows are from the Hopper's Landing site (41RF11) (courtesy of the Museum of the Coastal Bend). All line drawings by Richard McReynolds.

Our Calf Creek bison data derive from three sites: Spring Lake (41HY160), Eagle Bluff, and Cervenka; the latter two have only a single date each. A bison bone sample associated with a Bell point from Feature 2 at the Landslide site (41BL85; Sorrow et al. 1967) was curated at the Texas Archeological Research Laboratory and was submitted for dating as part of this study, but did not yield enough collagen to be reliably measured. Two separate contexts at Spring Lake, over $40 \mathrm{~m}$ apart, have yielded Calf Creek remains including 11 AMS dates on bison (Lohse et al. 2013). Conservatively, the 13 dates together span the interval from 5990-5715 cal B.P., taking the extreme 2 sigma ranges for the earliest and latest dates. However, most dates fall onto an ideal part of the calibration curve, centering around $5900 \mathrm{cal}$ B.P., between a modest reversal at about $5960 \mathrm{cal}$ B.P. and a minor plateau spanning from approximately 5850-5770 cal B.P. (Figure 5). The effect of these two parts of the curve is to draw out or extend the calibrated probabilities of the earliest and last dates. 
However, the difference of the earliest and latest dates allows us to estimate the duration of the Calf Creek components to be between 25 and 260 calibrated years (mean=140 cal years).

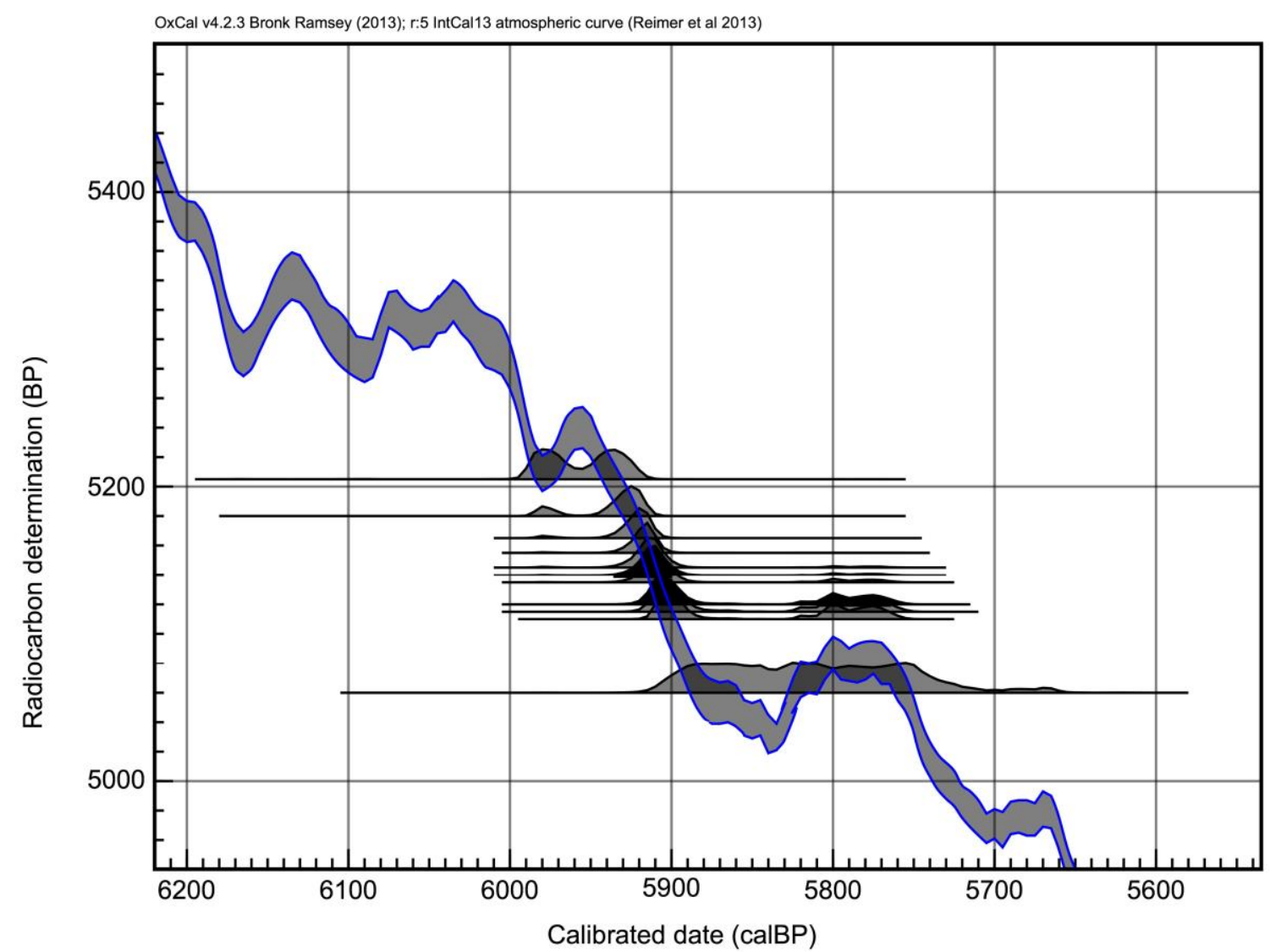

Figure 5. Calibrated probabilities for 13 Calf Creek dates superimposed on IntCal13 calibration curve.

Radiocarbon dates reported in association with Calf Creek materials commonly span over seven hundred years (see Wyckoff et al. 2009), and some "long" chronologies ascribe as much as a thousand years to this period (e.g., Collins 2004). Based on our results, however, we argue that this horizon may have been considerably shorter in duration. A moderately conservative treatment of these dates suggests a period of about 140 years. However, Bayesian modeling of the calibrated dates from Spring Lake suggests the presence of bison during a very short interval of no more than about 40 years (Figure 6), from 5937-5897 cal B.P. $\left(\mathrm{A}_{\text {model }}=122.3\right.$ ). This model indicates the short duration that can be identified with calibrated radiocarbon dates under ideal circumstances and with high-density sampling. The single date from Eagle Bluff is slightly earlier than this range, indicating regional variation in terms of timing and age of different site components. This model substantially narrows the overall age span for Calf Creek, and creates an opportunity to develop and test hypotheses relating to the overall chronology of bison movements and cultural responses during this period. 


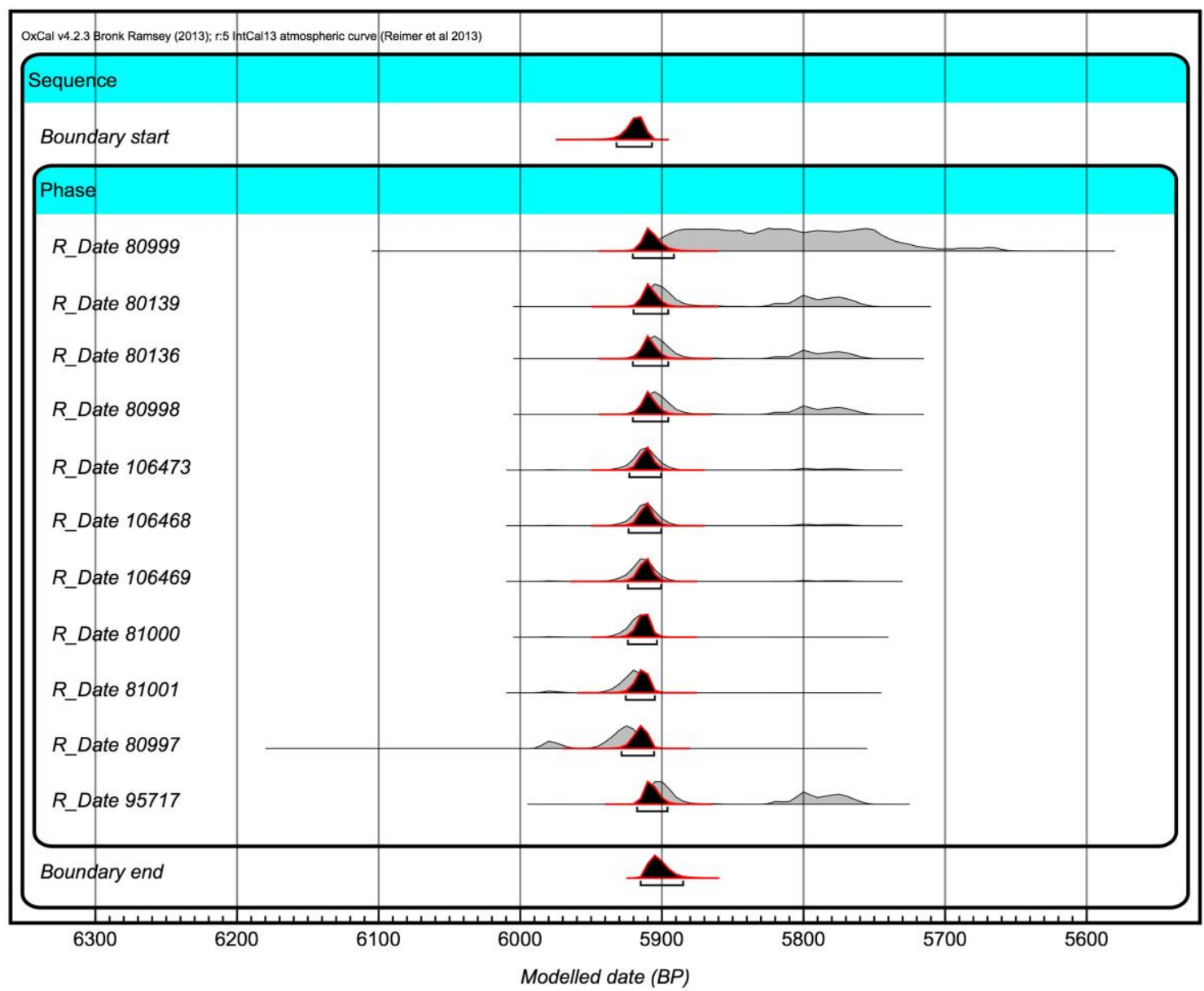

Figure 6. Simple Bayesian phase model of $\mathrm{AMS}{ }^{14} \mathrm{C}$ from Calf Creek deposits at Spring Lake. These data suggest that the occupation during this horizon may have been limited to only a single event or a few rapid visitations.

Other than our data, very few precise assays are available for this time period. A Calf Creek point embedded in a juvenile bison (B. occidentalis) skull found in river gravels near Tulsa, Oklahoma (Bement et al. 2005) and dated at $5120 \pm 20{ }^{14} \mathrm{C}$ years B.P. (approximately 5925-5760 cal B.P.) falls squarely within the range of dates we report. The Calf Creek component at the Kubik site, also in Oklahoma, has produced three dates: $4990 \pm 100$ (NZA6601) (5950-5465 cal B.P.), $5020 \pm 120$ (NZA6602), and $5050 \pm 60$ (Beta 98146) radiocarbon years B.P. (Neal 1999). The latter two dates, from a split nut hull, average to about 5895-5735 cal B.P. All three partially overlap with but are generally younger than our bison dates by a couple of centuries. The large 2 sigma probabilities of the Kubik dates relate to their large standard deviations compared with samples in our study, and also partly to a reversal in the calibration curve that occurs at ca. $5800 \mathrm{cal}$ B.P. (see Figure 5). However, the nutshell dates are considered highly reliable, and the Kubik data suggest that the Calf Creek horizon extended later in Oklahoma than in our study area. Additional sampling using precision dating protocols will be necessary to define the temporal extent of the Calf Creek horizon as it occurred elsewhere on the Southern Plains. 


\section{Late Archaic: ca. $3295-3130$ and 2700-2150 cal B.P.}

Following Calf Creek, bison appear to have been absent from the landscape for more than two thousand years, from ca. 5750-3300 cal B.P. Regional models (see Table 1) show bison throughout the Late Archaic, but are vague about when they appear and tend to treat the Late Archaic as a single undifferentiated period. Single component sites with bison dating to this time are uncommon. Most sites, like Wilson-Leonard, have mixed or compressed Late Archaic components. Our Late Archaic bison dates come from four sites: two Spring Lake sites (41HY160 and 41HY165), 41HY188, and Gault.

Our data suggest that Late Archaic bison exploitation took place over two distinct intervals. The first period $\left(\mathrm{LA}_{\mathrm{B}} 1\right.$ ) began by $3295 \mathrm{cal}$ B.P. (mean of 3355-3220 cal B.P., UCIAMS-95718) and continued until approximately 3130 cal B.P. (mean of 3215-3005 cal B.P., UCIAMS-80138). The duration of the period is estimated at between 55 and $270 \mathrm{cal}$ years, with a mean of $165 \mathrm{cal}$ years. This bison pulse is followed by a hiatus of at least 400 years (the 2 sigma difference is $380-700$ cal years) after which a subsequent pulse, $\mathrm{LA}_{\mathrm{B}} 2$, lasts from about 2700-2150 cal B.P. The more than 400 year hiatus after $3130 \mathrm{cal}$ B.P. is previously unreported, likely as a result of the reliance on archeological associations for reconstructing cultural patterns (Figure 7). Stable carbon and nitrogen isotope data indicate that Late Archaic climates were relatively stable for the entire $\mathrm{LA}_{\mathrm{B}} 1$ and $\mathrm{LA}_{\mathrm{B}} 2$ periods, and that both periods were somewhat warmer and had more effective moisture than the earlier Calf Creek or later Toyah periods (Lohse et al. 2014b). However, both also correspond with a period of globally cool climates (Wanner et al. 2011). Importantly, Viau et al. (2006) identify the period around 3000 B.P., approximately the middle of our postulated hiatus, as among the warmest of the entire North American Holocene and van Geel et al. (1996) identify a cool, moist period in Europe and North America starting by around 2650 cal B.P. If verified, these temperature changes could help explain or contextualize bison movements into and out of the study area at different times during the Late Archaic period.

Although there appears to be a gap in bison exploitation in $\mathrm{LA}_{\mathrm{B}} 2$ between ca. 2275 and $2415{ }^{14} \mathrm{C}$ B.P. (see Table 2), this gap is likely an artifact of the calibration curve. A plateau in the curve occurs during $\mathrm{LA}_{B} 2$, followed by a steep decline and then another mild reversal. These statistical plateaus affect the interpretation of radiocarbon data most obviously by creating very broad calibrated distributions for the dates in these groups. Indeed, the estimated length of $\mathrm{LA}_{\mathrm{B}} 2$ (200-550 cal years) is the longest in our study, and it is possible that the duration of this period is overestimated because of fluctuations in the calibration curve during this interval.

A less obvious effect of the plateaus and associated steep segments of the curve is that even with precise measurements and very dense sampling, conventional ages corresponding to plateaus will be overrepresented, and those during steep sections may tend to be underrepresented (Calf Creek is an 


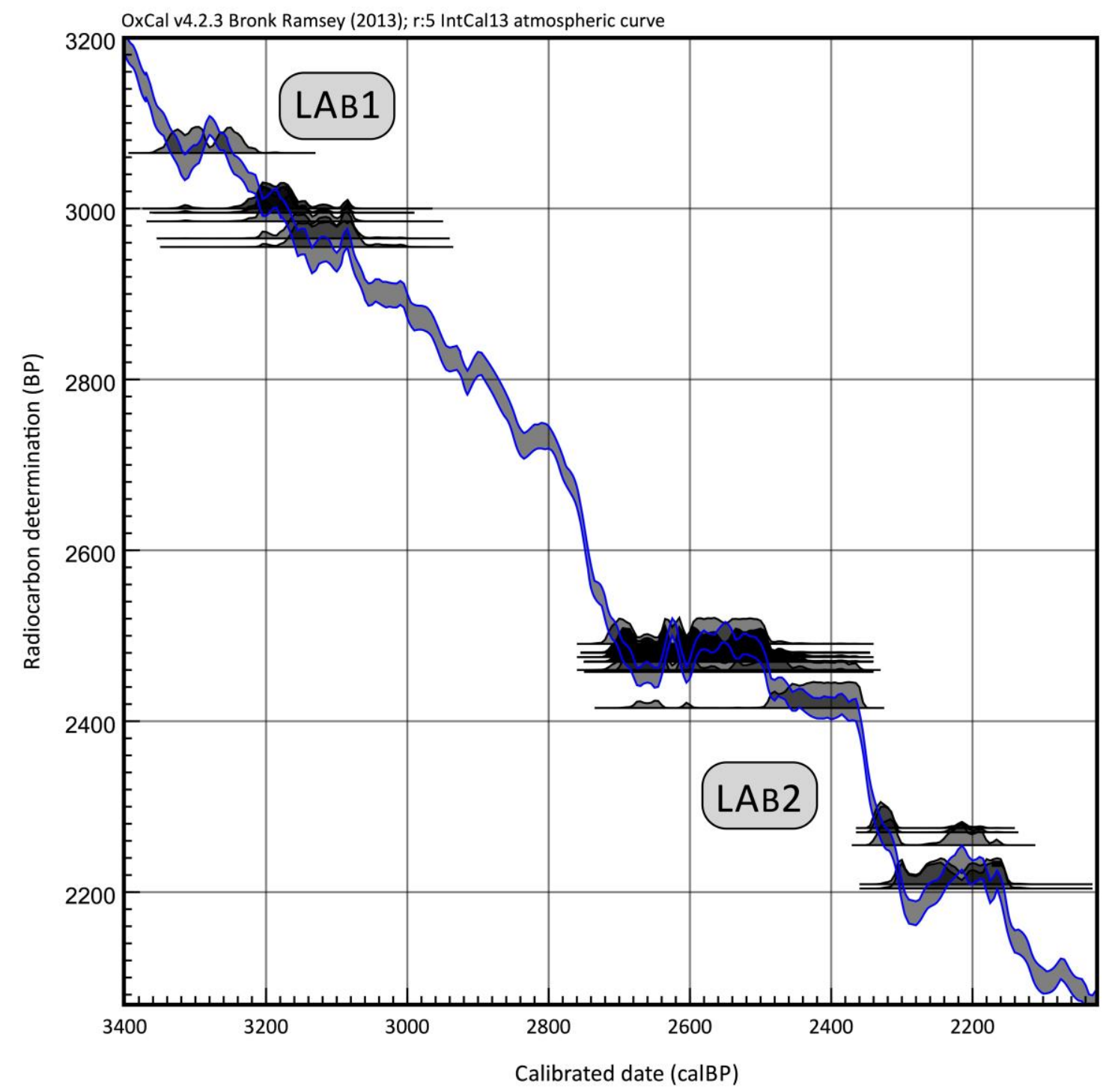

Figure 7. Calibrated probability distributions for 24 Late Archaic AMS ${ }^{14} \mathrm{C}$ bison dates. The $L A_{B} 2$ occupies a relatively flat part of the curve from about 2700-2360 cal B.P., which contributes to temporal imprecision during this interval. The steep decline following this plateau creates the appearance that a brief hiatus separates this period from a third Late Archaic period of bison exploitation.

exception; see Figure 5). This phenomenon can be modeled with OxCal using the $R \_$Simulate command, which produces a conventional age from a calendar age with a given measurement error, and then calibrates it. To better understand the effect of the curve on our calibrated sample, we simulated a group of 170 dates (10 dates every 25 years) from 2500 to 2100 cal B.P. assuming a measurement precision of $\pm 20{ }^{14} \mathrm{C}$ years to mirror the precision of our study. This very dense dataset is analogous to recovering and dating 40 bison per century from the archeological record, or roughly 10 times what we have sampled for the period. Plotting the frequency of conventional ages demonstrates that even at this density, conventional ages from ca. 2380 to $2260 \mathrm{cal}$ B.P. are relatively unlikely (roughly 10-20 percent as likely) to be sampled compared with ages on the plateaus before and after that time (Figure 8). The congruence between the distributions of simulated and observed 
conventional ages through this period suggests that the apparent gap is an artifact of the calibration curve, and that further sampling is unlikely to produce many more conventional ages between 2415 and $2275 \mathrm{ca}$. B.P.

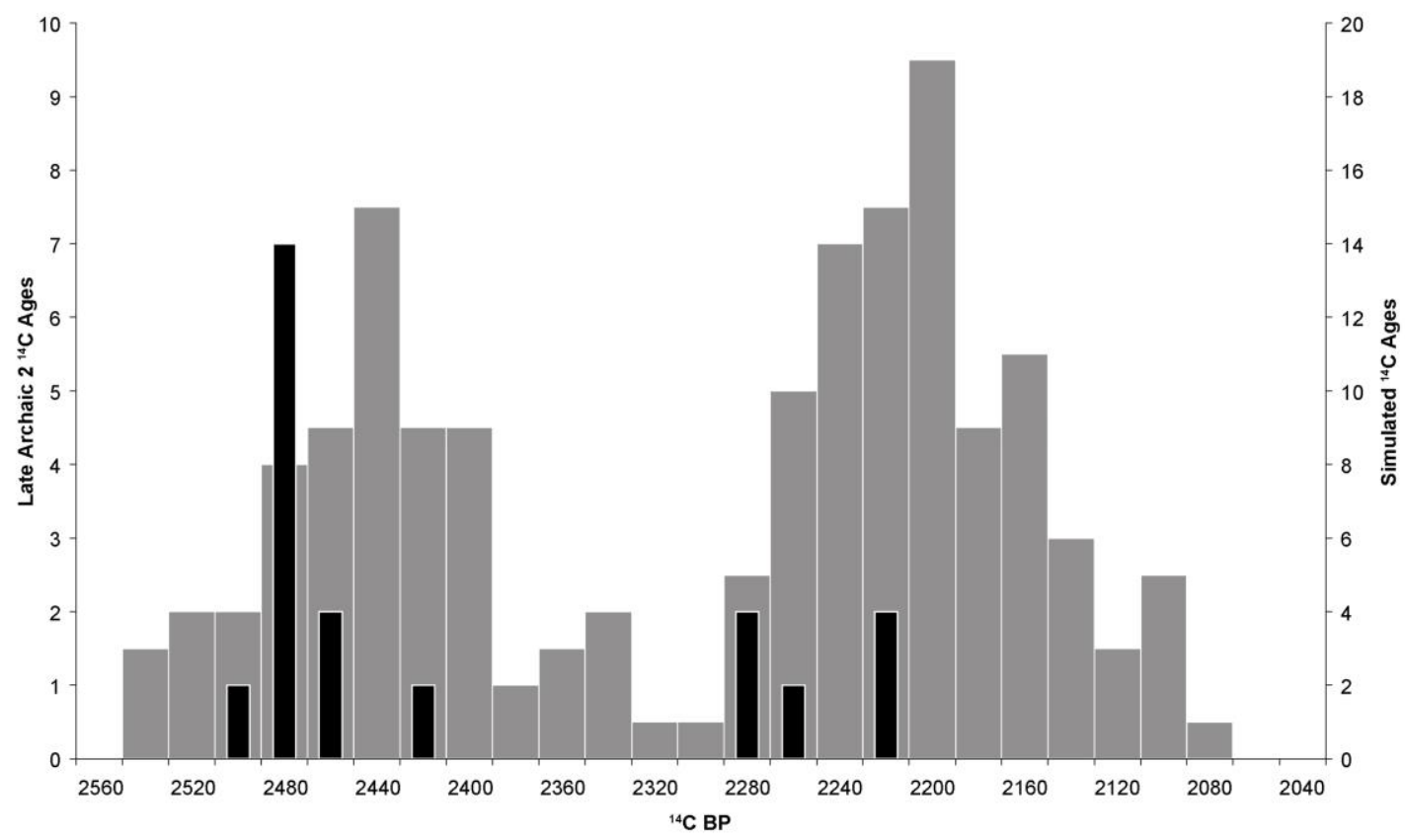

Figure 8. Frequency of simulated ${ }^{14} \mathrm{C}$ ages (gray columns) versus measured ${ }^{14} \mathrm{C}$ ages (black columns) on bison across two plateaus in the Late Archaic from 2500-2100 cal B.P. (2560-2040 14C yr B.P.) and the apparent gap in ${ }^{14} \mathrm{C}$ ages that is an artifact of the calibration curve. Simulated ages were generated in OxCal 4.17 (Bronk Ramsey 2010) using R_Simulate, assuming 10 dates every $25 \mathrm{cal}$ years and a precision of $\pm 20{ }^{14} \mathrm{C} \mathrm{yr}$, comparable to the precision of the dates in this study. The "gap" in $\mathrm{LAB}_{2}{ }^{14} \mathrm{C}$ ages is likely not a true hiatus in bison exploitation.

\section{Toyah: 650-530 cal B.P.}

Following the Late Archaic, bison again appear to have been absent from the study area for approximately 1500 years, until ca. 650 cal B.P. They reappeared suddenly and may have been present for less than $120 \mathrm{cal}$ years before once again disappearing. This Toyah bison interval is the shortest in our study. Climatically, our early Toyah bison period occurred immediately after the onset of the Little Ice Age (LIA), a prolonged cool and dry period, the beginning of which corresponds with one of the largest volcanic events of the entire Holocene as well as severely reduced solar activity (Mayewski et al. 2004; Wanner et al. 2011). Stable carbon and nitrogen isotope data (Lohse et al. 2014b) indicate that temperatures during this brief interval were not as cool as the Calf Creek period, and that effective moisture was slightly greater than in the Calf Creek period. However, the period was still cooler and drier than either $\mathrm{LA}_{\mathrm{B}} 1$ or $\mathrm{LA}_{\mathrm{B}} 2$. The LIA was complex climatologically, and significant variation has been documented within it. Based on over a thousand tree-ring, ice core, coral, sediment, and other proxy records, Mann et al. (2009) reconstruct a brief cold period in the northern hemisphere centering around A.D. 1340 (ca. $610 \mathrm{cal} \mathrm{B.P.)} \mathrm{that} \mathrm{precedes} \mathrm{a} \mathrm{short} \mathrm{warm}$ interval before temperatures decline once again just prior to ca. A.D. 1500 (ca. $450 \mathrm{cal} \mathrm{B.P.).} \mathrm{The}$ reconstructed cool periods correspond with the Wolf and Spöer grand solar minima, respectively 
(Bard et al., 2000; Steinhilber and Beer 2011), brief intervals of reduced solar activity (e.g., sun spots, solar flares, etc.) that are associated with global cooling.

The bimodal calibrated distributions of our 20 dates from this period (Figure 9) partially reflect the shape of the calibration curve during this interval, which exhibits a sharp reversal resulting in paired intercepts for each assay. Taking the difference of the oldest and youngest dates in our Toyah bison period, the period lasted between 10 and $120 \mathrm{cal}$ years, with a mean of $70 \mathrm{cal}$ years. Toyah dates come from five sites: two Spring Lake sites (41HY160 and 41HY165), 41HY188, Eagle Bluff, and McNeill.

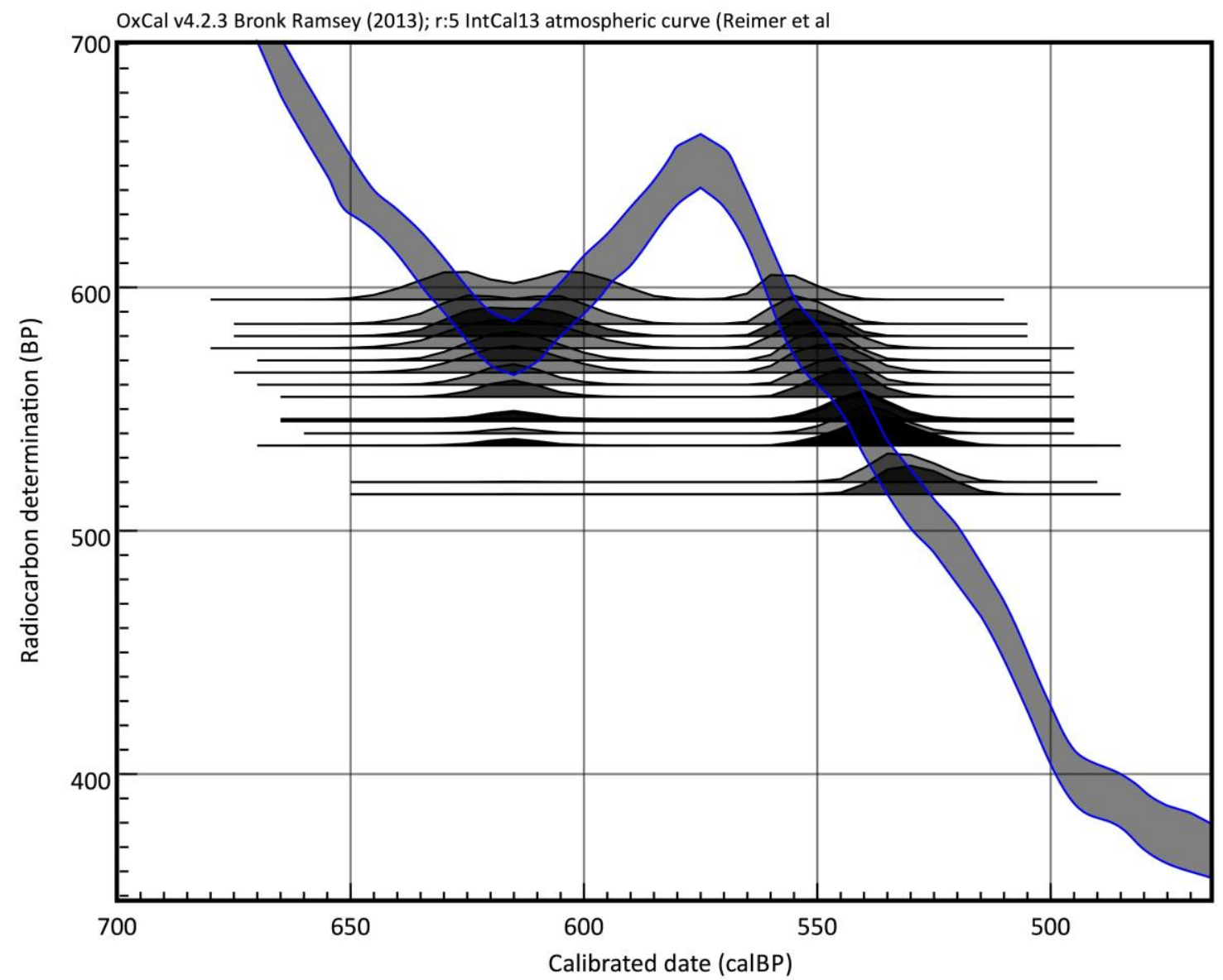

Figure 9. Calibrated probability distributions for 20 early Toyah AMS 14C bison dates. The reversal at ca. 575 cal B.P., resulting in bimodal distributions, causes the calibrated span of time to cover a longer period than is likely. Nonetheless, this is the shortest period of bison exploitation documented in our study.

The brevity of this period of bison exploitation is significant in the culture history of North America. In the regional sequence, the Toyah horizon begins by approximately $650 \mathrm{cal}$ B.P. or A.D. 1300, and lasts as late as A.D. 1700. Native American cultural practices extending to the end of this sequence are difficult to link with earlier prehistoric antecedents because of the influences of Spanish entradas and colonization, not to mention population declines and social disruptions due to European diseases and group displacement practices that started in the early 1500s (Arnn 2012; Kenmotsu and 
Hester 2001). Nonetheless, Toyah culture has typically been defined as exhibiting a technological focus on the exploitation of bison (Johnson 1994; Kenmotsu and Boyd 2012; Prewitt 2012; Ricklis 1994) and artiodactyls generally (Black 1986). Some have noted variation in Toyah subsistence practices (e.g., Dering 2008; Mauldin et al. 2013), including what appears as a decreased emphasis in bison, but temporal controls frequently lack the precision needed to demonstrate whether this variation is temporal or geographic in nature.

Archeologists argue that Toyah is important for our broader anthropological understanding of hunter-gatherer cultural patterns just prior to ethnographically-documented foragers that occupied the region when the Spanish arrived (Collins 1995). Our data suggest that the Toyah horizon may have been characterized by more varied subsistence practices and associated social and technological adaptations than conventional views suggest. From the early A.D. 1500s through the late 1700s, historical groups were recorded pursuing bison across Texas (Arnn 2012; Speth 2004; Wade 2003), and it has been widely presumed that this pattern is an extension of practices that began as early as A.D. 1300 (ca. 650 cal. B.P.). Prior research on the southern Plains has documented widespread trade between Puebloan settlements to the west and Plains groups focusing on bison meat, hide, and other products (Boyd 1997; Creel 1991; Krieger 1946; Prewitt 1982; Speth and Newlander 2012; Spielmann 1991; Vehik 1990, 2002). Considering the sudden appearance of bison and their role in both subsistence and economic patterns, we suggest that early Toyah (ca. A.D. 1300-1420, or 650-530 cal B.P.) can be partly understood as a southern extension of this interregional system. Our findings suggest, however, that middle Toyah sites, those dating after around 530 cal B.P. (A.D. 1420), but pre-dating the reappearance of bison in the mid-1500s, may have maintained an altogether different orientation, with significantly less reliance on bison than previously thought. Although sites with late Toyah material such as the Rush site (41TG346, ca. A.D. 1575; Quigg 1997) or the upper Toyah component at Rowe Valley (41WM437; Prewitt 2012) contain bison and appear to support this threepart model of Toyah chronology, dating resolution is so far lacking to demonstrate the postulated middle Toyah facet. However, the four historic dates in our sample provide partial support for this model. More dates are needed from this late period before this model can be further developed.

\section{DISCUSSIONS AND CONCLUSIONS}

Our record of 61 AMS dates on bison bone recovered from archeological contexts from the southeastern periphery of the Great Plains adds to what is known about the exploitation of a topranked resource starting approximately 6000 years ago. We show that bison were present only occasionally since the Early-Middle Holocene. While our study is generally consistent with previous regional models, it adds important precision to the overall understanding of these periods. It is well known that bison were present in the region prior to $6000 \mathrm{cal}$ B.P., but this part of the record has not been directly dated using the XAD-based protocols we report here. Because the early sequence for bison exploitation is dated primarily by archeological association, in our view it remains imprecise.

In spite of its limitations in terms of geographic and temporal coverage, our record of XADpurified AMS ${ }^{14} \mathrm{C}$ dates on bison offers one of the most precise models for the presence and prehistoric exploitation of this key resource anywhere in North America. In addition to refining local and 
regional chronologies, our findings also contribute to hypotheses about fluctuations in "Plains-like" cultural patterns that depended, in part, on environmental and climatic change and the subsequent exploitation of bison for subsistence and economic purposes. For example, what appears as the sudden onset of bison-related cultural patterns, especially Calf Creek and Toyah, may have been associated with rapid climate change (Mayewski et al. 2004). This important possibility, which deserves further attention, would have significant implications for how archeologists understand the nature and timing of prehistoric culture change. Additionally, the rapid appearance of widespread horizons associated with the Calf Creek and early Toyah periods is ostensibly linked to the sharing of weapons- and processing-related technologies involved with logistically organized bison hunting at these times. Projectile point styles associated with these intervals are among the most widespread postPaleoindian styles in Texas (cf. Prewitt 1995), and may reflect the distances traveled by bison hunters and the kinds of social encounters that occurred as part of these forays.

More than only subsistence practices are implicated as well. Trade patterns beginning by A.D. 1250 (ca. 700 cal B.P.) in the Southern Plains and focused on bison are also well known (e.g., Creel 1991; Speth 2004). Toyah sites commonly show a sharp increase in exotic materials compared with earlier periods (Kibler 2012), suggesting that exchange networks also extended south into Central and southern Texas. Like connections with climate change, this proposition also requires much additional research before these economic processes are fully understood. Future AMS radiocarbon dating work on Toyah sites should be mindful of our evidence suggesting a three-part bison chronology. Sample selection should avoid large carbonized wood fragments susceptible to the old wood effect and focus instead on annuals or perennials. Radiocarbon results should be matched against zooarcheological assemblages indicating the presence or absence of bison.

Our study highlights the research value of adding to the record of XAD-purified AMS dates of bison remains. Adding samples with greater time depth and from additional sites will help improve the bison record and increase its usefulness as a means for understanding larger cultural and environmental processes at the southern extent of the far Southern Plains.

\section{ACKNOWLEDGEMENTS}

Funding for this study was provided by Texas State University and by Mr. Arnold Coldiron. Cinda L. Timperley provided identifications of all bison material from 41HY160, 41HY165, and 41HY188. Thomas R. Hester was the Principal Investigator of the Texas Archeological Society field school at 41ME147, and Harry J. Shafer supervised the work at that site and helped identify and make available the two samples from this site. Permission to include the sample from the Cervenka site was granted by Daniel McGregor of the United States Army Corps of Engineers, Ft. Worth District, and Laura Nightengale of the Texas Archeological Research Laboratory at The University of Texas at Austin helped coordinate that de-accession. Eric Ray and the Museum of the Coastal Bend, Victoria, Texas, granted permission to include two samples from 41VT141. Bill Birmingham was helpful in making available Calf Creek remains from the Coastal Bend area, and Bobby Gray shared information about Calf Creek from Brewster and Jeff Davis counties. The Gault School for Archaeological Research kindly allowed us to include a sample from 41BL323. Derek Hamilton 
provided assistance with the phase model shown in Figure 5. Michael Collins, Elton Prewitt, Raymond Mauldin, and several anonymous reviewers offered helpful comments on earlier drafts of this article. Finally, we deeply appreciate Tim Perttula's editorial guidance.

\section{REFERENCES CITED}

Ambrose, S. H. and L. Norr

1992 On Stable Isotopic Data and Prehistoric Subsistence in the Soconusco Region. Current Anthropology 33:401-404.

Arnn, J. W. III

2012 Land of the Tejas: Native American Identity and Interaction in Texas, A.D. 1300 to 1700. The University of Texas Press, Austin.

Baker, B. W.

1998 Vertebrate Faunal Remains from the 1/4-Inch and 1/8-Inch Screens. In Wilson-Leonard, an 11,000-Year Archeological Record of Hunter-Gatherers in Central Texas. Volume V: Special Studies, edited by M. B. Collins, pp. 1463-1509. Studies in Archeology 31, Texas Archeological Research Laboratory, The University of Texas at Austin and Archeology Studies Program, Report 10, Texas Department of Transportation, Environmental Affairs Division, Austin.

Bamforth, D. B.

1988 Ecology and Human Organization on the Great Plains. Plenum Press, New York.

2011 Origin Stories, Archaeological Evidence, and Post-Clovis Paleoindian Bison Hunting on the Great Plains. American Antiquity 76:24-40.

Bard, E., G. Raisbeck, F. Yiou, and J. Jouzel

2000 Solar Irradiance During the Last 1200 Years Based on Cosmogenic Nuclides. Tellus 52B:985992.

Baugh, S. T.

1986 Late Prehistoric Bison Distributions in Oklahoma. Plains Anthropologist 31:83-96.

Bayliss, A.

2009 Rolling Out Revolution: Using Radiocarbon Dating in Archaeology. Radiocarbon 51(1):123147.

Bement, L. C.

1986 Excavation of the Late Pleistocene Deposits of Bonfire Shelter, 41VV218, Val Verde County, Texas. Archeology Series 1. Texas Archeological Survey, The University of Texas at Austin.

Bement, L. C. and K. J. Buehler

1994 Preliminary Results from the Certain Site: A Late Archaic Bison Kill in Western Oklahoma. Plains Anthropologist 39:173-183. 
Bement, L. C., E. L. Lundelius, Jr., and R. A. Ketcham

2005 Hoax or History: A Bison Skull with Embedded Calf Creek Projectile Point. Plains

Anthropologist 50:221-226.

Bettis, Jr., A. C.

1996 Archaeological Investigations at 41HY188, Hays County, Texas, 1988: A Study of the Archaeological Remains and Lithic Technology. Master's Thesis, Department of Anthropology, The University of Texas at Austin.

Black, S. L.

1986 The Clemente and Herminia Hinojosa Site, 41JW8: A Toyah Horizon Campsite in Southern Texas. Special Report 18. Center for Archaeological Research, University of Texas at San Antonio.

Boyd, D. K.

1997 Caprock Canyonlands Archeology: A Synthesis of the Late Prehistory and History of Lake Alan Henry and the Texas Panhandle-Plains. Reports of Investigations No. 110. Prewitt and Associates, Inc., Austin.

Bozell, J. R., C. R. Falk, and E. Johnson

2011 Native American Use of Animals on the North American Great Plains. In The Subsistence Economies of Indigenous North American Societies: A Handbook, edited by B. D. Smith, pp. 353385. Smithsonian Institution Scholarly Press, Washington, D.C.

Bronk Ramsey, C.

2010 OxCal version 4.17. http://c14.arch.ox.ac.uk/embed.php?file=oxcal.html.

Brown T. A, D. E. Nelson, J. S. Vogel, and J. R. Southon

1988 Improved Collagen Extraction by Modified Longin Method. Radiocarbon 30(2):171-177.

Calame Sr., D., C. Weber, L. Banks, and R. McReynolds

2002 Projectile Points of the Calf Creek Horizon from Frio, Medina, and Uvalde Counties, Southern Texas. La Tierra 29:29-38.

Carlson, K. and L. Bement

2013 Organization of Bison Hunting at the Pleistocene/Holocene Transition on the Plains of North America. Quaternary International 297:93-99.

Carmichael, D.

1986 Archaeological Survey in the Southern Tularosa Basin. Historic and Natural Resources Report No. 3, Environmental Management Office, Directorate of Engineering and Housing, United States Army Air Defense Artillery Center, Fort Bliss, and Publications in Anthropology No. 10, E1 Paso Centennial Museum, University of Texas at E1 Paso. 
Collins, M. B.

1994 Evidence of Early Archaic Occupation. In Human Ecology in the Middle Onion Creek Valley, Hays County, Texas, by R. A. Ricklis and M. B. Collins, pp. 67-100. Studies in Archeology 19. Texas Archeological Research Laboratory, The University of Texas at Austin.

1995 Forty Years of Archeology in Central Texas. Bulletin of the Texas Archeological Society 66:361400.

2004 Archeology in Central Texas. In The Prehistory of Texas, edited by T. K. Perttula, pp. 101-126. Texas A\&M University Press, College Station.

Collins, M. B. (assembler and editor)

1998 Wilson-Leonard: An 11,000-Year Archeological Record in Central Texas. 6 Volumes. Studies in Archeology 31, Texas Archeological Research Laboratory, The University of Texas at Austin, and Archeology Studies Program Report 10, Texas Department of Transportation, Environmental Affairs Division, Austin.

Cooper, J. R.

2008 Bison Hunting and Late Prehistoric Human Subsistence Economies in the Great Plains. Ph.D. Dissertation, Department of Anthropology, Southern Methodist University, Dallas.

Creel, D. G.

1991 Bison Hides in Late Prehistoric Exchange in the Southern Plains. American Antiquity 56:4049.

Denham, T., C. Bronk Ramsey, and J. Specht

2012 Dating the Appearance of Lapita Pottery in the Bismarck Archipelago and its Dispersal to Remote Oceania. Archaeology in Oceania 47:39-46.

Dering, $P$.

2008 Late Prehistoric Subsistence Economy on the Edwards Plateau. Plains Anthropologist 53:59-77.

DeNiro, M.

1985 Postmortem Preservation and Alteration of In Vivo Bone Collagen Isotope Ratios in Relation to Palaeodietary Reconstruction. Nature 317:806-809

Dibble, D. S. and D. H. Lorrain

1968 Bonfire Shelter: A Stratified Bison Kill Site, Val Verde, County, Texas. Miscellaneous Papers No. 1. Texas Memorial Museum. The University of Texas at Austin.

Dickson, D. R.

1970 Excavations at Calf Creek Cave. The Arkansas Archeologist 11:50-82. 
Dillehay, T. D.

1974 Late Quaternary Bison Population Changes on the Southern Plains. Plains Anthropologist 19:180-196.

Duncan, M.

1996 Test Excavations at the Kubic Site, 34KA354. Oklahoma Archeological Survey Newsletter 15:1.

Fenner, J. N.

2007 Prehistoric Hunting on the Range Where the Antelope Play: Archaeological Pronghorn Bed Formation Analysis. Ph.D. Dissertation, Department of Anthropology, University of Wyoming, Laramie.

Frison, G. C.

1991 Prehistoric Hunters of the High Plains. Second edition. Academic Press, New York.

1998 The Northwestern and Northern Plains Archaic. In Archaeology of the Great Plains, edited by W. R. Wood, pp. 140-172. University Press of Kansas, Lawrence.

2004 Survival by Hunting: Prehistoric Human Predators and Animal Prey. University of California Press, Berkeley.

Gray, R. W.

2013 Diagnostic Artifacts of Paleoindian and Early Archaic Cultures in the Eastern Trans-Pecos Region of Texas. In Archeological Explorations of the eastern Trans-Pecos and Big Bend: Collected Papers, Volume 1, edited by P. Dasch and R. J. Mallouf, pp. 1-59. Papers of the Tans-Pecos Archaeological Program 6. Center for Big Bend Studies, Sul Ross State University, Alpine.

Grayson, D. K.

2006 Holocene Bison in the Great Basin, Western USA. The Holocene 16:913-925.

Guthrie, R. D.

1980 Bison and Man in North America. Canadian Journal of Anthropology 1:55-73.

Hester, T. R.

2004 The Prehistory of South Texas. In The Prehistory of Texas, edited by T. K. Perttula, pp. 127151. Texas A\&M University Press, College Station.

2010 An Overview of Excavations at the Eagle Bluff Site and Other Activities of the 2010 Texas Archeological Society Field School. Texas Archeology (Newsletter of the Texas Archeological Society) 54:1, 3-5.

2011 A Summary of the 2011 Texas Archeological Society Field School. Texas Archeology (Newsletter of the Texas Archeological Society) 55:1, 3-11. 
Huebner, J.

1991 Late Prehistoric Bison Populations in Central and Southern Texas. Plains Anthropologist 36:343-358.

Johnson, E.

1987 Vertebrate Remains. In Lubbock Lake: Late Quaternary Studies on the Southern High Plains, edited by E. Johnson, pp. 49-89. Texas A\&M University Press, College Station.

Johnson, E. and V. T. Holliday

1987 Introduction. In Lubbock Lake: Late Quaternary Studies on the Southern High Plains, edited by E. Johnson, pp. 3-13. Texas A\&M University Press, College Station.

Johnson, L., Jr.

1994 The Life and Times of Toyah-Culture Folk: The Buckhollow Encampment, Site 41KM16, Kimble County, Texas. Office of the State Archeologist Report 38. Texas Historical Commission and Texas Department of Transportation, Austin.

Kenmotsu, N. A. and D. K. Boyd (editors)

2012 The Toyah Phase of Central Texas: Late Prehistoric Economic and Social Processes. Texas A\&M University Press, College Station.

Kenmotsu, N. A. and T. R. Hester

2001 Conflict, Migration, and Coalescence: Native American Groups in Texas, A.D. 1530-1878. Bulletin of the Texas Archeological Society 72:1-3.

Kennett, D. J., B. J. Culleton, J. Dexter, S. A. Mensing, and D. H. Thomas

2014 High-Precision AMS 14C Chronology for Gatecliff Shelter, Nevada. Journal of Archaeological Science, http://dx.doi.org/10.1016/j.jas.2014.06.008. Manuscript in press.

Kennett, D. J., B. J. Culleton, B. Voorhies, and J. R. Southon

2011 Bayesian Analysis of High-Precision AMS 14C Date from a Prehistoric Mexican Shellmound. Radiocarbon 53:245-259.

Kibler, K. W.

2012 The Role of Exotic Materials in Toyah Assemblages in a Late Prehistoric Economic and Social System. In The Toyah Phase of Central Texas: Late Prehistoric Economic and Social Processes, edited by N. A. Kenmotsu and D. K. Boyd, pp. 76-89. Texas A\&M University Press, College Station.

Krieger, A. D.

1946 Culture Complexes and Chronology in Northern Texas with Extension of Puebloan Datings to the Mississippi Valley. Publication 4640. The University of Texas, Austin. 
List, R., G. Ceballos, C. Curtin, P. J. P. Gogan, J. Pacheco, and J. Truett

2007 Historic Distribution and Challenges to Bison Recovery in the Northern Chihuahua Desert. Conservation Biology 21:1487-1494.

Lohse, J. C. (editor)

2013 Underwater Archaeology at 41HY147, the Terrace Locality at Spring Lake. Archaeological Studies Report No. 28. Center for Archaeological Studies, Texas State University-San Marcos.

Lohse, J. C., S. L. Black, and L. M. Cholak

2014a Toward an Improved Archaic Radiocarbon Chronology for Central Texas. Bulletin of the Texas Archeological Society 85:251-279.

Lohse, J. C., D. B. Madsen, D. J. Kennett, and B. J. Culleton

2014b Paleoecological Implications of a High-Precision Chronology for Episodic Mid-to-Late Holocene Bison Population Expansions in the Southern Plains, U.S.A. Quaternary Science Reviews, in press.

Lohse, J. C., A. E. Reid, D. M. Yelacic, and C. L. Timperley

2013 Data Recovery and Analysis of the Texas State University Ticket Kiosk at 41HY160, Spring Lake, Hays County, Texas. Archaeological Studies Report No. 32. Center for Archaeological Studies, Texas State University-San Marcos.

Longin, R.

1971 New method of collagen extraction for radiocarbon dating. Nature 230:241-242.

Lynott, M. J.

1979 Prehistoric Bison Populations of North Central Texas. Bulletin of the Texas Archeological Society 50:89-101.

Mann, M. E., Z. Zhang, S. Rutherford, R. S. Bradley, M. K. Hughes, D. Shindell, C. Ammann, G. Faluvegi, and F. Ni

2009 Origins of the Little Ice Age and Medieval Climate Anomaly. Science 326:1256-1259.

Mauldin, R. P., R. J. Hard, C. M. Munoz, J. L. Z. Rice, K. Verostick, D. R. Potter, and N. Dollar

2013 Carbon and nitrogen stable isotope analysis of hunter-gatherers from the Coleman site, a Late Prehistoric cemetery in Central Texas. Journal of Archaeological Science 40:1369-1381.

Mauldin, R., J. Thompson, and L. Kemp

2012 Reconsidering the Role of Bison in the Terminal Late Prehistoric (Toyah) Period of Texas. In The Toyah Phase of Central Texas: Late Prehistoric Economic and Social Processes, edited by N. A. Kenmotsu and D. K. Boyd, pp. 90-110. Texas A\&M University Press, College Station. 
Mayewski, P. A., E. E. Rohling, J. C. Stager, W. Karlén, L. A. Laasch, L. D. Meeker, E. A. Meyerson, F. Gasse, S. van Kreveld, K. Holmgren, J. Lee-Thorp, G. Rosqvist, F. Rack, M. Staubwasser, R. R. Schneider, and E. J. Steig

2004 Holocene Climate Variability. Quaternary Research 62:243-255.

McReynolds, R. L.

2002 Calf Creek Horizon Points from Wilson County, Texas. La Tierra 29:39-44.

Meltzer, D. J.

2006 Folsom: New Archaeological Investigations of a Classic Paleoindian Bison Kill. University of California Press, Berkeley.

Neal, L.

1999 Dating the Kubic Site, 34KA354. Oklahoma Archeological Survey Newsletter 19:1-3.

Neal, L. and M. Duncan

1998 Mid-Holocene Radiocarbon Dates from the Kubic Site (34KA354). Oklahoma Archeological Survey Newsletter 18:2.

O'Brien, M. J. and W. R. Wood

1998 The Prehistory of Missouri. University of Missouri Press, Columbia.

Peter, D., D. Prikryl, O. McCormick, and M.-A. Demunck

1982 Site Excavation Reports: Primary Contract. In Archaeological Investigations at the San Gabriel Reservoir Districts, Central Texas. Volume 1, edited by T. R. Hays, pp. 8-1 to 8-297. Archaeology Program, Institute of Applied Sciences, North Texas State University, Denton.

Prewitt, E. R.

1982 Archeological Investigations at the Loeve-Fox, Loeve and Tombstone Bluff Sites in the Granger Lake District of Central Texas. Volume 4, Archaeological Investigations of the San Gabriel Reservoir Districts, Central Texas. Archaeology Program, Institute of Applied Sciences, North Texas State University, Denton.

1983 Andice: An Early Archaic Dart Point. La Tierra 10:1-10.

1995 Distributions of Typed Project Points in Texas. Bulletin of the Texas Archeological Society 66:83173.

2012 Toyah: Reflections on Evolving Perceptions. In The Toyah Phase of Central Texas: Late Prehistoric Economic and Social Processes, edited by N. A. Kenmotsu and D. K. Boyd, pp. 181203. Texas A\&M University Press, College Station.

Quigg, J. M.

1997 Bison Processing at the Rush Site, 41TG346, and Evidence for Pemmican Production in the Southern Plains. Plains Anthropologist 42:145-161. 
Reimer, P. J., E. Bard, A. Bayliss, J. W. Beck, P. G. Blackwell, C. B. Ramsey, C. E. Buck, H. Cheng, R. L. Edwards, M. Friedrich, P. M. Grootes, T. P. Guilderson, H. Haflidason, I. Hajdas, C. Hatté, T. J. Heaton, D. L. Hoffmann, A. G. Hogg, K. A. Hughen, K. F. Kaiser, B. Kromer, S. W. Manning, M. Niu, R. W. Reimer, D. A. Richards, E. M. Scott, J. R. Southon, R. A. Staff, C. S. M. Turney, and J. van der Plicht

2013 IntCal13 and Marine 13 Radiocarbon Age Calibration Curves, 0-50,000 Years Cal BP. Radiocarbon 55:11869-1887.

Ricklis, R. A.

1988 Archeological Investigations at the McKinzie Site (41NU221), Nueces County, Texas: Description and Contextual Interpretations. Bulletin of the Texas Archeological Society 58:1-76.

1992 The Spread of a Late Prehistoric Bison Hunting Complex: Evidence from the South-Central Coastal Prairie of Texas. Plains Anthropologist 37:261-273.

1994 Toyah Components: Evidence for Occupations in the Project Area during the Latter Part of the Late Prehistoric Period. In Archaic and Late Prehistoric Human Ecology in the Middle Onion Creek Valley, Hays County, Texas, by R. A. Ricklis and M. B. Collins, pp. 207-316. Studies in Archeology 19. Texas Archeological Research Laboratory, The University of Texas at Austin.

Ross, R. E.

1965 The Archaeology of Eagle Cave. Papers of the Texas Archeological Salvage Project 7. The University of Texas at Austin.

Santos G. M., J. R. Southon, K. C. Druffel-Rodriguez, S. Griffin, and M. Mazon

2004 Magnesium Perchlorate as an Alternative Water Trap in AMS Graphite Sample Preparation: A Report on Sample Preparation at the KCCAMS Facility at the University of California, Irvine. Radiocarbon 46(1):165-173.

Sichler, J. A., J. L. Vavrasek, K. D. Hollenbach, and J. C. Lohse

2011 Faunal Remains and Analysis. In Prehistoric Life, Labor, and Residence in Southeast Central Texas: Results of Data Recovery at 41HY163, the Zatopec Site, San Marcos, Texas, edited by J. C. Lohse, pp. 351-386. Archaeological Studies Report No. 18. Center for Archaeological Studies, Texas State University-San Marcos.

Sorrow, W. M., H. J. Shafer, and R. E. Ross

1967 Excavations at Stillhouse Hollow Reservoir. Papers No. 11. Texas Archeological Salvage Project, The University of Texas at Austin.

Speth, J. D.

2004 Life on the Periphery: Economic Change in Late Prehistoric Southeastern New Mexico. Memoirs No. 37. Museum of Anthropology, University of Michigan, Ann Arbor. 
Speth, J. D. and K. Newlander

2012 Plains-Pueblo Interaction: A View from the Middle. In The Toyah Phase of Central Texas: Late Prehistoric Economic and Social Processes, edited by N. A. Kenmotsu and D. K. Boyd, pp. 152180. Texas A\&M University Press, College Station.

Spielmann, K. A. (editor)

1991 Farmers, Hunters, and Colonists: Interaction Between the Southwest and the Southern Plains. University of Arizona Press, Tucson.

Stafford, T. W., Jr., K. Brendel, and R. C. Duhamel

1988 Radiocarbon, 13C and 15N Analysis of Fossil Bone: Removal of Humates with XAD-2 resin. Geochimica et Cosmochimica Acta 52:2257-2267.

Stafford, T. W., Jr., P. E. Hare, L. A. Currie, A. J. T. Jull, and D. Donahue 1991 Accelerator Radiocarbon Dating at the Molecular Level. Journal of Archaeological Science 18:35-72.

Steinhilber, R. and J. Beer

2011 Solar Activity - the Past 1200 Years. PAGES news 19:5-6.

Stites, M. D.

2006 The Calf Creek Complex: Preliminary Research on the Lithic Technology in Kansas. Oklahoma Archeology 54:10-42.

Stuiver, M. and H. A. Polach

1977 Discussion: Reporting of ${ }^{14} \mathrm{C}$ Data. Radiocarbon 19(3):355-363.

Thurmond, J. P. and D. G. Wyckoff

1999 The Calf Creek Horizon in Northwestern Oklahoma. Plains Anthropologist 44:231-250.

Tieszen, L. T., K. J. Reinhard, and D. L. Foreshoe

1997 Appendix C: Stable Isotopes in the Central and Northern Great Plains. In Bioarchaeology of the North Central United Stated: A Volume in the Central and Northern Plains Archeological Overview, edited by D. W. Owsley and J. C. Rose, pp. 329-336. Research Series No. 49. Arkansas Archeological Survey, Fayetteville.

Tzedakis, C.

2003 Timing and Duration of Last Interglacial Conditions in Europe: A Chronicle of Changing Chronology. Quaternary Science Reviews 22:763-768.

Van Geel, B., J. Buurman, and H. T. Waterbolk

1996 Archaeological and Palaeoecological Indications of an Abrupt Climate Change in the Netherlands, and Evidence for Climatological Teleconnections around 2650 BP. Journal of Quaternary Science 11:451-460. 
van Klinken, G. J.

1999 Bone Collagen Quality Indicators for Palaeodietary and Radiocarbon Measurements. Journal of Archaeological Science 26:687-695.

Vehik, S. C.

1990 Late Prehistoric Plains Trade and Economic Specialization. Plains Anthropologist 35:125-145.

2002 Conflict, Trade, and Political Development on the Southern Plains. American Antiquity 67:3764 .

Viau, W. E., K. Gajewski, M. C. Sawada, and P. Fines

2006 Millennial-Scale Temperature Variations in North America During the Holocene. Journal of Geophysical Research, vol. 111. Doi:10.1029/2005JD006031.

Wade, $\mathrm{M}$.

2003 Native Americans of the Edwards Plateau, 1582-1799. The University of Texas Press, Austin.

Walter, R. W.

2013 The Elusive Calf Creek Horizon in the Big Bend. In Archeological Explorations of the eastern Trans-Pecos and Big Bend: Collected Papers, Volume 1, edited by P. Dasch and R. J. Mallouf, pp. 61-70. Papers of the Tans-Pecos Archaeological Program 6. Center for Big Bend Studies, Sul Ross State University, Alpine.

Wanner, H., O. Solomina, M. Grosjean, S. P. Ritz, and M. Jetel

2011 Structure and Origin of Holocene Cold Events. Quaternary Science Reviews 30:3109-3123.

Waters, M. R. and T. W. Stafford

2007 Supporting Online Material for Redefining the Age of Clovis: Implications for the Peopling of the Americas. Science 315:1122-1126.

2014 Redating the Mill Iron Site, Montana: A Reexamination of Goshen Complex Chronology. American Antiquity 79:541-548.

Waters, M. R., T. W. Stafford, H. G. McDonald, C. Gustafson, M. Rasmussen, E. Cappellini, J. V. Olsen, D. Szklarczyk, L. J. Jensen, M. T. P. Gilbert, and E. Willerslev

2011 Pre-Clovis Mastodon Hunting 13,800 Years Ago at the Manis Site, Washington. Science 334:351-353.

Widga, C., J. D. Walker, and L. D. Stockli

2010 Middle Holocene Bison diet and mobility in the eastern Great Plains (USA) based on $\delta^{13} \mathrm{C}$, $\delta^{18} \mathrm{O}$, and ${ }^{87} \mathrm{Sr} /{ }^{86} \mathrm{Sr}$ analyses of tooth enamel carbonate. Quaternary Research 73:449-463.

Wilmshurst, J. M., T. L. Hunt, C. P. Lipo, and A. J. Anderson

2011 High-Precision Radiocarbon Dating Shows Recent and Rapid Initial Human Colonization of East Polynesia. Proceedings of the National Academy of Sciences 108:1815-1820. 
Wyckoff, D. G.

1994 Introduction to the 1991 Bulletin. Bulletin of the Oklahoma Anthropological Society XL:1-8.

1995 A Summary of the Calf Creek Horizon in Oklahoma. Bulletin of the Oklahoma Anthropological Society XLII:179-210.

Wyckoff, D. G., E. Dowd, and D. J. Cranford

2009 Summary Perspectives of Soils and Prehistory along Oklahoma's Cross Timbers. In Geoarchaeology and the Cross Timbers, edited by D. J. Cranford, E. L. Dowd, and D. G. Wyckoff, pp. 75-104. Memoir 13. Oklahoma Anthropological Society, Norman.

Wyckoff, D. G. and L. D. Richens

2010 The Curious Archaic: Calf Creek in Utah? Bulletin of the Oklahoma Anthropological Society LVIII:1-18. 


\title{
A PRECISE CHRONOLOGY OF MIDDLE TO LATE HOLOCENE BISON EXPLOITATION IN THE FAR SOUTHERN GREAT PLAINS
}

\author{
Jon C. Lohse, Brendan J. Culleton, Stephen L. Black, and Douglas J. Kennett
}

\begin{abstract}
In regions on the margins of the Great Plains grasslands, documenting the intermittent history of bison exploitation has presented challenges to archeologists. Chronologies based on archeological associations have long been useful in regional research, but can be imprecise and of inadequate resolution for constructing precise sequences of prehistoric events. Here, we present a record of directly dated bison from archeological contexts spanning the last 6000 years on the very southern extent of the Great Plains. This study includes 61 specimens from archeological contexts that were dated by XAD purified AMS radiocarbon, with reported errors of only 15-20 14C years for most dates. The resulting record of bison exploitation for this area defines four main periods (Calf Creek, Late Archaic 1 and 2, and early Toyah) during which bison were exploited. Several dates also indicate an early historic presence of bison; this period may represent a late facet of the Toyah horizon. This study adds significant chronological resolution to the regional record of bison in parts of Texas and begins to help correlate cultural chronologies with important climatic data. It also points to the research value of obtaining additional directly dated bison samples from temporally and geographically diverse archeological contexts in our study area and beyond.
\end{abstract}

\section{INTRODUCTION}

The North American genus Bison was among the very top-ranked resources available to huntergatherers up to and even following the arrival of European explorers. Millennia of bison hunting on the Plains are documented from Early Paleoindian times onward (Bamforth 1988, 2011; Bement and Buehler 1994; Bozell et al. 2011; Carlson and Bement 2013; Cooper 2008; Frison 1991, 1998, 2004; Guthrie 1980). In Late Prehistoric times, agriculturalists in the American Southwest and Mississippi River drainages to the east often hunted bison or traded for their products, bringing them into frequent contact with Plains tribes (Creel 1991; Spielmann 1991; Speth 2004; Speth and Newlander 2012; Vehik 1990, 2002). Bison exploitation, for meat and other uses, has played a significant role in shaping prehistoric and early historic economies across the Plains. As a top-ranked food resource, the

\footnotetext{
JOURNAL OF TEXAS ARCHEOLOGY AND HISTORY

VOLUME 1:94-126

THE ONLINE PUbliCATION JOURNAL OF TEXAS ARCHEOLOGY AND HISTORY (ISSN 2334-1874)

IS PUBLISHED BY JOURNAL OF TEXAS ARCHEOLOGY AND HISTORY.ORG.

COPYRIGHT (C) 2014 JOURNAL OF TEXAS ARCHEOLOGY AND HistORY.ORG. All RIGHTS RESERVED.
} 
presence of bison would have had tremendously important implications for prehistoric subsistence practices, mobility, the organization of labor, and other social characteristics.

While bison were present almost continuously in the cool, predominantly $\mathrm{C}_{3}$ grasslands of the Northern Plains, only occasionally in the Middle to Late Holocene periods did they extend into other environments characterized by mixed grasslands or other habitats. These areas include parts of the Great Basin (Grayson 2006), northern Mexico (List et al. 2007), and the southern limits of the Plains that include Central and coastal Texas (Baugh 1986; Dillehay 1974; Huebner 1991; Lynott 1979; Mauldin et al. 2012; Ricklis 1992). Understanding precisely when bison were present in regions located around the periphery of the Plains is important not only for our general knowledge regarding bison ecology, climate, and environmental change in North America, but also for providing insights into human responses during these periods.

In this study, we present and evaluate AMS radiocarbon data for $61 \mathrm{XAD}$ purified samples of bison bone recovered from archeological contexts at seven sites located in Central and South Texas. The culture history of these areas shares much with Plains traditions to the north during some time intervals, while maintaining their own distinct patterns during others (Collins 1995, 2004; Hester 2004; Lohse et al. 2014a). Precisely defining periods when bison were present in these areas has been a challenge, largely as a result of the traditional reliance on dating bison by association with other archeological remains. Our approach involves directly dating bison from archeological contexts as a way to avoid the imprecision that can result from dating by association. The resulting chronology defines four primary periods of prehistoric bison exploitation beginning around $6000 \mathrm{cal} \mathrm{B.P.} \mathrm{and} \mathrm{also}$ indicates an early Historic use by North American Indians. Earlier periods of bison presence remain to be worked out for these areas, ideally using a similar methodology to the one we discuss herein. This precise chronology not only clarifies regional prehistoric subsistence and related technological practices, but can also help researchers correlate cultural developments with environmental or paleoclimatic data that may be associated with periods of rapid cultural change.

\section{DATING BISON IN THE STUDY AREA AND THE PRESENT SAMPLE}

Beginning with Dillehay (1974), many investigators have examined the issue of bison presence in the region (Baugh 1986; Collins 1995; Huebner 1991; Lynott 1979; Mauldin et al. 2012; Quigg 1997; Ricklis 1992). These studies commonly evaluate the presence of bison at a regional scale based on archeological components that are themselves dated by radiocarbon or by cross-dating using associated time-marker artifacts (Table 1). Typically, bison presence is modeled as a series of long periods of presence or absence, the beginnings and endings of which are imprecisely dated.

In contrast to regional models, single-site records (such as the one at Wilson-Leonard, 41WM235 [Collins 1998]), where bison were not present for certain intervals when they appear elsewhere, exemplify the limitations of site-specific studies. A given site's stratigraphy may be compressed or mixed, affecting an analysts' ability to precisely reconstruct periods of bison exploitation. This condition most directly and adversely affects bison chronologies that rely on archeological association. In other cases, a single site's occupation history may not include periods during which 
bison were present nearby. For example, Bonfire Rockshelter (41VV218) offers a fascinating record of bison hunting during certain periods in the Lower Pecos of southwest Texas, including Late Archaic,

Table 1. Some models of bison presence and visibility in the study region.

\begin{tabular}{|c|c|c|c|c|}
\hline Southern Plains (Dillehay 1974) & \multicolumn{2}{|c|}{ Central Texas (Mauldin et al. 2012) } & \multicolumn{2}{|c|}{$\begin{array}{l}\text { Wilson-Leonard (Sichler et al. } \\
\text { 2011, from data by Baker 1998) }\end{array}$} \\
\hline $\begin{array}{l}\text { Presence Period } 3 \\
800 \text { B.P. }\end{array}$ & $\begin{array}{l}473.8 \text { avg. } \\
\text { NISPI } \\
\text { component }\end{array}$ & 700-400 B.P. & $\begin{array}{l}18 \mathrm{NISP} / \\
\text { component }\end{array}$ & $1700-4200$ B.P. \\
\hline $\begin{array}{l}\text { Absence Period } 2 \\
1500-800 \text { B.P. }\end{array}$ & $\begin{array}{l}2.9 \text { avg. } \\
\text { NISPI } \\
\text { component }\end{array}$ & $1250-700$ B.P. & $\begin{array}{l}1 \mathrm{NISP} / \\
\text { component }\end{array}$ & 4200-5200 B.P. \\
\hline $\begin{array}{l}\text { Presence Period } 2 \\
4500-1500 \text { B.P. }\end{array}$ & $\begin{array}{l}7.3 \text { avg. } \\
\text { NISPI } \\
\text { component }\end{array}$ & 1600-1250 B.P. & $\begin{array}{l}59 \mathrm{NISP} / \\
\text { component }\end{array}$ & $\begin{array}{l}>11,000- \\
9000 \text { B.P. }\end{array}$ \\
\hline $\begin{array}{l}\text { Absence Period } 1 \\
\text { ca. } 7000 \text { B.P.-4500 B.P. }\end{array}$ & $\begin{array}{l}316.9 \text { avg. } \\
\text { NISP/ } \\
\text { component }\end{array}$ & 2500-1600 B.P. & & \\
\hline $\begin{array}{l}\text { Presence Period } 1 \\
>11,000-7000 \text { B.P. }\end{array}$ & $\begin{array}{l}6.0 \text { avg. } \\
\text { NISP/ } \\
\text { component }\end{array}$ & 4450-2500 B.P. & & \\
\hline
\end{tabular}

Folsom, and perhaps Clovis times (Bement 1986; Dibble and Lorrain 1968). However, this record does not include bison remains from the Calf Creek horizon, material traces of which are reported in nearby Eagle Cave (41VV167, Ross 1965) as well as from Jeff Davis and Brewster counties some 150 $\mathrm{km}$ to the west (Gray 2013; Walter 2013), indicating that the record at Bonfire Rockshelter does not completely reflect the character of regional bison histories.

Our study draws from several sites geographically dispersed across a wide area. We do not imply that our study area corresponds with any particular archeological region(s). Indeed, the size of what might be called a "bison catchment" that is represented by this study is not precisely known. However, previous research indicates the potential size of prehistoric bison ranges. Carlson and Bement (2013) estimate mobility ranges from ca. $100 \mathrm{~km}$ (Clovis times) to up to ca. $600 \mathrm{~km}$ (late Folsom times) in diameter in an area centered on Oklahoma that includes southern Kansas, the Texas Panhandle, and eastern New Mexico. Widga et al. (2010) reconstruct inter-annual movements of $\leq 500 \mathrm{~km}$ over a period of about 4-5 years for Early/Middle Holocene (ca. 7-8.5 ka) bison in the eastern Great Plains of eastern Nebraska, South Dakota, western Iowa, and southwest Wisconsin. An area of ca. $600 \mathrm{~km}$ in diameter easily encompasses all of the sites from which samples in this study were taken (Figure 1). 


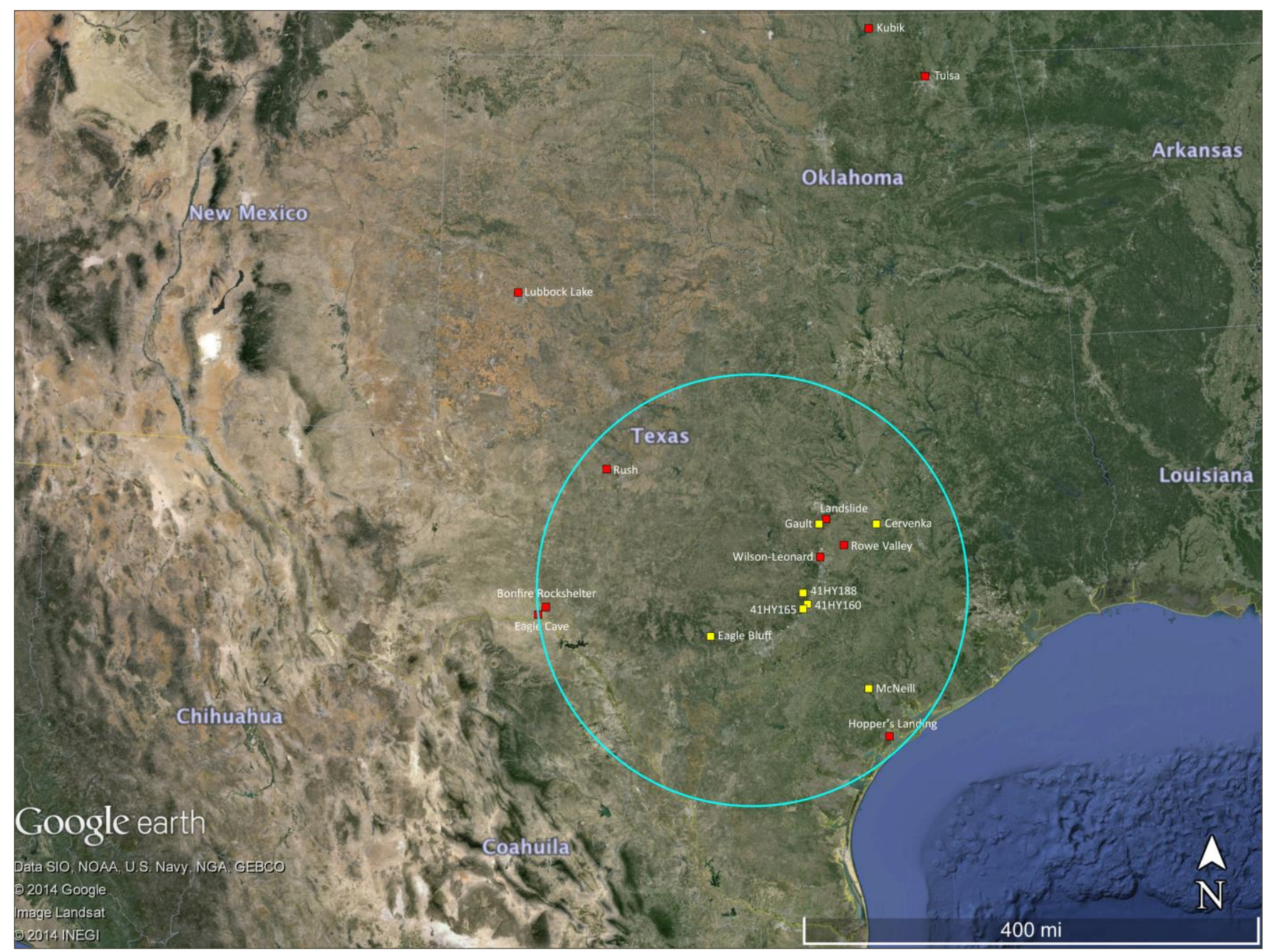

Figure $1.600 \mathrm{~km}$ diameter study area illustrating the distance prehistoric herds may have travelled if they maintained mobility patterns comparable to those reconstructed elsewhere in North America. Sites dated in this study are shown in yellow; other sites discussed in the text are shown in red.

The presence of bison in the archeological record is, first, the result of environmental process and, second, a reflection of hunter-gatherer behavior. The key to building reliable bison chronologies, therefore, involves the number of temporal components that are sampled (i.e., selected for direct dating) within a given bison range. We propose that bison histories can be accurately reconstructed using sites with intermittent occupation records, so long as each period of bison presence in the total study area is well represented in at least one site's deposits. Alternatively, large portions of a bison chronology can also be compiled from a small number of sites, assuming that each period during which bison were present on the landscape is represented in site components and has been sampled. In this approach, compiling a large number of assays (i.e., high sample density) helps to ensure that all or most intervals of bison presence within the region are included. A weakness of this approach is that the geographic limits of bison territorial ranges will likely remain poorly known until sampling densities clearly define the geographic limits for each temporal period of bison presence. 
Minimally, the patterns presented below are valid for the sites and time periods included in our study. Although we consider it likely that these patterns reflect larger-scale trends across a much broader area, only future sampling following the methods we employ here can precisely identify the extent of territorial ranges that are associated with the temporal periods in our chronology. For example, reports of bison presence throughout the Holocene at Lubbock Lake (41LU1) (Johnson 1987; Johnson and Holiday 1987) seem to suggest that the chronology presented here does not extend to the Texas Panhandle (see Figure 1).

Our sample draws heavily from $41 \mathrm{HY} 160$ and HY165, sites that are associated with Spring Lake, formed by impounded freshwater springs at the headwaters of the San Marcos River in Hays County, Texas. Based on temporally diagnostic artifacts and radiocarbon data (Figure 2), the Spring Lake sites exhibit a nearly continuous record of occupation from Clovis to historical periods (Lohse 2013). These sites are important to this study because their essentially continuous sequence means that remains of bison, as a top-ranked food resource, should be expected to occur whenever bison were present on the surrounding landscape. The occupation record of these sites distinguishes them from others, like Bonfire, with intermittent histories of site use. Controlled excavations at Spring Lake have generally not extended below the Early Archaic archeological deposits and intensive archeological sampling has only been conducted to ca. 6000 cal B.P. depths (Lohse et al. 2013), which represents the temporal limit of our study. Another site (41HY188) is less than $5 \mathrm{~km}$ from Spring Lake and evidences Late Prehistoric and Late Archaic occupation associated with bison (Bettis 1996). Two other specimens come from Eagle Bluff (41ME147) in Medina County (Hester 2010, 2011), one from Gault (41BL323) in Bell County, two from McNeill (41VT141) in Victoria County, and one from Cervenka (41WM267) in Williamson County (Peter et al. 1982). Each site contains deep, multi-component deposits in stratified alluvial settings, and is interpreted as a long-term encampment, making it unlikely that bison were killed at any of these locations. Rather, butchered remains were likely transported from kill sites back to these occupation areas for additional processing.

Assemblages from 41HY160, 41HY165, and 41HY188 were examined for bison remains suitable for dating. Virtually all specimens identified as bison were fragmented to the point that age and sex could not be consistently estimated. Therefore, no age and sex data are presented for the bison from any of our study sites. All cataloged contexts were evaluated, and specimens were selected from as many different proveniences by depth and site area as possible. Through this approach, every time period characterized by bison presence (and sampled by controlled excavation) had an equal chance of being identified. As noted, high sampling density was a priority in order to better model periods of bison presence. Samples were included from the other sites based on accessibility, preservation, and the limits of available funding.

Selected specimens were pre-treated for collagen extraction and purification using a XAD process modified from earlier work by Stafford that isolates individual amino acid chains (Stafford et al. 1988, 1991). Two modern approaches to removing exogenous carbon from bone collagen samples have been developed and refined over the last two decades: modified Longin (1971) extraction with ultrafiltration (Brown et al. 1988) and XAD-purification (Stafford et al. 1988, 1991). Ultrafiltration works 


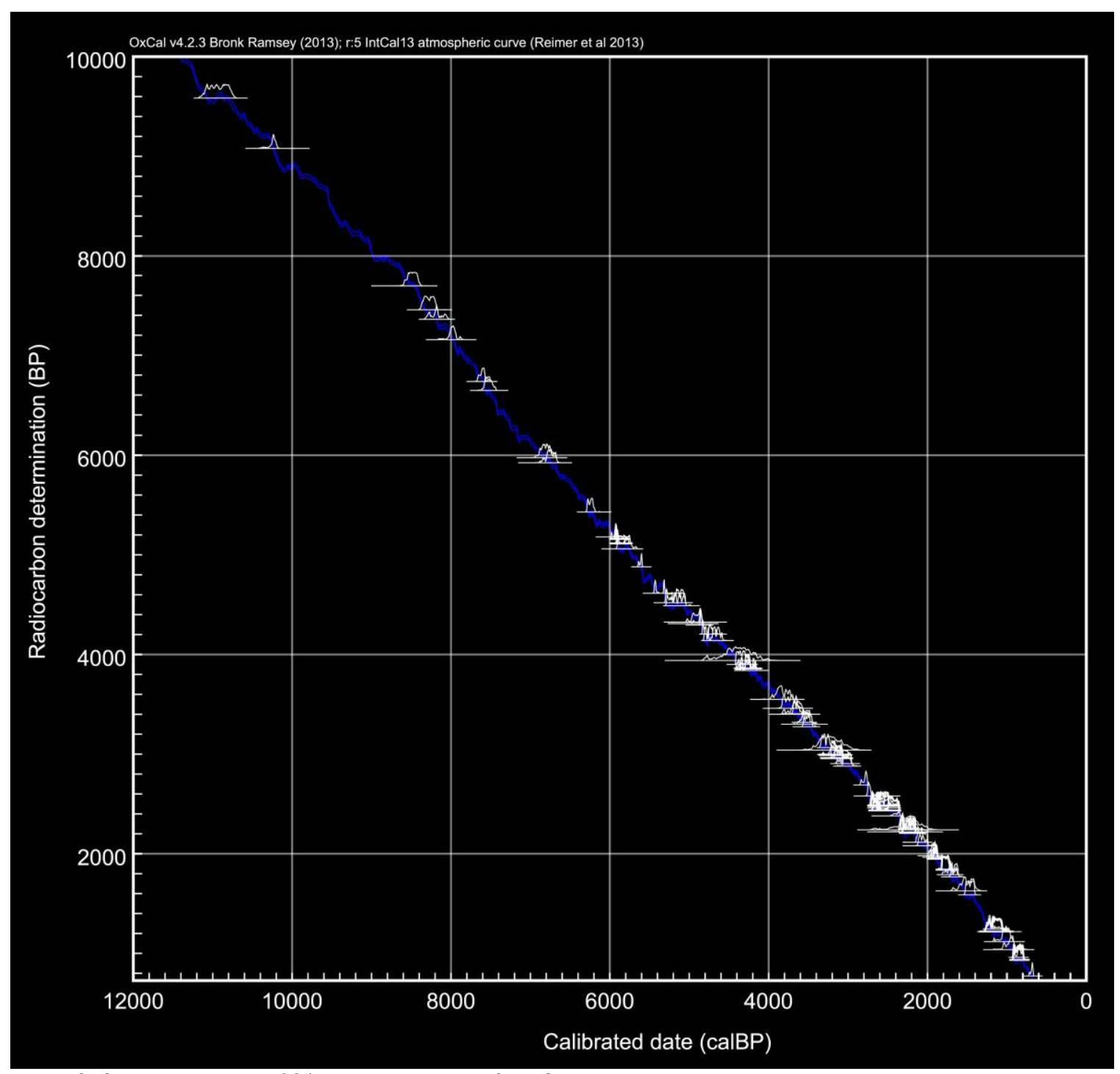

Figure 2. Calibrated results of 94 radiocarbon dates from Spring Lake, showing the nearly continuous occupation record extending to just after $6000 \mathrm{cal} \mathrm{B.P.} \mathrm{and} \mathrm{the} \mathrm{subsequent} \mathrm{decline} \mathrm{of} \mathrm{dates} \mathrm{that} \mathrm{reflects} \mathrm{the} \mathrm{limits} \mathrm{of} \mathrm{controlled}$ excavations. Two older dates not from archeological contexts are excluded (redrawn from Lohse 2013:Figure 4-1).

by retaining long-chain gelatin molecules (typically larger than $30 \mathrm{kDa}$ ) and filtering out smaller, potentially degraded gelatin molecules and contaminating humates smaller than $30 \mathrm{kDa}$. The lower yield of datable gelatin that results from ultrafiltration can limit its use on very poorly preserved bone (e.g., in cases where little or no long-chain protein survives), but smaller chains may be recoverable. One advantage of the modified XAD method is that all of the crude gelatin extracted from the bone can be processed for stable isotope measurement and AMS ${ }^{14} \mathrm{C}$ dating. Another advantage is that exogenous carbons that can remain following ultrafiltration treatments are removed, ensuring greater accuracy of measured ages.

Stafford et al. (1988, 1991) argued that gelatinization as described by Longin (1971) is not adequate to disassociate all humic and fulvic acids bound to collagen and that contaminants may cross-bind with smaller degraded collagen chains to create longer chains that would be retained in the 
filter. Our approach to eliminating these contaminants is to break the collagen down to individual amino acids by hydrolysis in concentrated $(6 \mathrm{~N}) \mathrm{HCl}$, thereby releasing humic and fulvic acids into solution. Polar contaminants are then removed from the solution by chromatography using a column filled with XAD resin. The method used in this study is adapted from that of Stafford et al. (1988, 1991). Similar methods of XAD amino acid dating has been used to reliably reevaluate pre-Clovis, Clovis, and other Early Paleoindian chronologies in North America (Waters and Stafford 2007, 2014; Waters et al. 2011) by dating osseous remains and artifacts clearly associated with Terminal Pleistocene cultural deposits.

At the Human Paleoecology and Isotope Geochemistry Lab at Pennsylvania State University, each sample was cleaned and sectioned with disposable Dremel cut-off wheels and then demineralized in $0.5 \mathrm{~N} \mathrm{HCl}$ for two to three days at $5^{\circ} \mathrm{C}$. The demineralized collagen pseudomorph was then gelatinized at $60^{\circ} \mathrm{C}$ in $4-5 \mathrm{~mL} 0.01 \mathrm{~N} \mathrm{HCl}$ for eight to 10 hours. Sample gelatin was pipetted into a pre-cleaned $10 \mathrm{ml}$ disposable syringe with an attached $0.45 \mu \mathrm{m}$ Millex Durapore PVDF filter (precleaned with methanol and Nanopure $\mathrm{H}_{2} \mathrm{O}$ ) and driven into a thick-walled culture tube. The filtered solution was then lyophilized and percent gelatinization and yield determined by weight. The sample gelatin was then hydrolyzed in $2 \mathrm{~mL} 6 \mathrm{~N} \mathrm{HCl}$ for 22 hours at $110^{\circ} \mathrm{C}$. Supelco ENVI-Chrom ${ }^{\circledR}$ SPE (Solid Phase Extraction; Sigma-Aldrich) columns were prepped with two washes of methanol $(2 \mathrm{~mL})$ and rinsed with $10 \mathrm{ml}$ DI $\mathrm{H}_{2} \mathrm{O}$. With a $0.45 \mu \mathrm{m}$ Millex Durapore filter attached, the SPE Column was equilibrated with $50 \mathrm{~mL} 6 \mathrm{~N} \mathrm{HCl}$ and the washings discarded. $2 \mathrm{~mL}$ collagen hydrolyzate as $\mathrm{HCl}$ was pipetted onto the SPE column and driven with an additional $10 \mathrm{ml} 6 \mathrm{~N} \mathrm{HCl}$ dropwise with the syringe into a $20 \mathrm{~mm}$ culture tube. The hydrolyzate was finally dried into a viscous syrup by passing UHP $\mathrm{N}_{2}$ gas over the sample heated at $50^{\circ} \mathrm{C}$ for ca. $12 \mathrm{hr}$.

Stable carbon and nitrogen isotope measurements, $\% \mathrm{C}$ and $\% \mathrm{~N}$, were determined on amino acid hydrolyzate samples $(\sim 0.7 \mathrm{mg})$ at the University of California, Irvine Keck Carbon Cycle Accelerator Mass Spectrometer facility, on a Fisons NA1500NC elemental analyzer/Finnigan Delta Plus isotope ratio mass spectrometer with a precision of $<0.1 \%$ for $\delta^{13} \mathrm{C}$ and $\delta^{15} \mathrm{~N}$. Only samples with atomic C:N ratios between 3.0-3.4, indicative of good collagen preservation (Ambrose and Norr 1992; DeNiro 1985; van Klinken 1999), were submitted for AMS ${ }^{14} \mathrm{C}$ dating and are included in this study. AMS samples ( 4.0 mg) were combusted for three hours at $900^{\circ} \mathrm{C}$ in vacuum-sealed quartz tubes with $\mathrm{CuO}$ wire and $\mathrm{Ag}$ wire to produce sample $\mathrm{CO}_{2}$. Sample $\mathrm{CO}_{2}$ was reduced to graphite at $550^{\circ} \mathrm{C}$ using $\mathrm{H}_{2}$ and a Fe catalyst, with reaction water drawn off with $\mathrm{C}-9 \mathrm{Mg}\left(\mathrm{ClO}_{4}\right)_{2}$ (Santos et al. 2004). Graphite samples were pressed into targets in Al boats and loaded on a target wheel with OX-1 (oxalic acid) standards, known age bone secondaries, and a ${ }^{14} \mathrm{C}$-free Pleistocene whale blank. The ${ }^{14} \mathrm{C}$ measurements were made on a modified National Electronics Corporation compact spectrometer with a $0.5 \mathrm{MV}$ accelerator (NEC 1.5SDH-1). Analytical error in the 2-3\%o range was achieved, which for the current study translates to standard deviations in the range of $\pm 15-20{ }^{14} \mathrm{C}$ years. Radiocarbon ages were $\delta^{13} \mathrm{C}$-corrected for mass dependent fractionation with $\delta^{13} \mathrm{C}$ values measured on the AMS (Stuiver and Polach 1977), and compared with samples of Pleistocene whale bone (background, $>48 \mathrm{k}$ ${ }^{14} \mathrm{C}$ B.P.), a ca. $12400{ }^{14} \mathrm{C}$ B.P. horse bone, ca. $1840{ }^{14} \mathrm{C}$ B.P. bison bone, late A.D. 1800 s cow bone, and OX-1 oxalic acid standards for calibration. All dates are calibrated with the IntCal13 curve (Reimer et al. 2013) using OxCal 4.2 (Bronk Ramsey 2010) and are presented in calibrated years 
before present (cal B.P.). In order not to imply undue precision, all results are rounded to the nearest five-year interval (Table 2).

Regarding data presented in Table 2, a small number $(n=4)$ of statistical outliers are present in our sample. Statistical outliers in each temporal period that contain five or more specimens are those samples with $\delta^{13} \mathrm{C}$ values more than 1.5 times the interquartile range below the first quartile or higher than the third quartile (Fenner 2007). These specimens are identified in Table 2 as having very low (negative) $\delta^{13} \mathrm{C}$ values. No statistical outliers were identified based on $\delta^{15} \mathrm{~N}$. Outliers such as these are often reported from archeological bison herds such as at Folsom (Meltzer 2006:Table 6.19) and JonesMiller (Tieszen et al. 1997), and elsewhere we have speculated that these may represent sexually mature bulls that had migrated into the study area from elsewhere (Lohse et al. 2014b). We are not aware of any research to date that has focused specifically on explaining or interpreting these outliers, but they are not uncommon in archeological studies of prehistoric bison isotopes.

We define periods of bison presence (also called temporal groups) based on the clustering of calibrated ${ }^{14} \mathrm{C}$ dates. In addition to standard calibration we calculate the duration of each period as the Difference of the earliest and latest samples in each group using $\mathrm{OxCal}$, and summarize the range with means of those dates. Because we are unlikely to have directly dated the earliest or latest bison for any of our temporal groups, future dating is likely to affect the span of one or more groups. OxCal's Sum command is used to visually summarize the distributions within each group of dates, but this is merely a heuristic rather than an analytical tool. Because of the high density of samples taken from 41HY160, $41 \mathrm{HY} 165$, and $41 \mathrm{HY} 188$, it is possible that the same animals from these sites may have been dated more than once. If such cases exist, however, they do not adversely affect our chronology, since assays are only used to indicate when bison were hunted, and are not used to reconstruct herd population dynamics. Evaluating the individual carbon and nitrogen isotope measurements for each sample (shown in Table 2) shows that no two samples returned the same radiocarbon and isotope values. This suggests that any duplicate measurement of the same animal is minimal.

As noted, one result of our analytical approach is that the resulting chronology has greater precision than temporal models based on traditional (i.e., non-pretreated) bone dating and/or those relying on archeological association. While such methods have long provided useful information about the general timing of events, they are not well suited for addressing the precise timing of prehistoric events or when researchers are interested in documenting periods of rapid or punctuated cultural adaptations. Precise chronologies, sometimes also called "short chronologies" (e.g., Denham et al. 2012; Kennett et al. 2011, 2014; Tzedakis 2003; Wilmshurst et al. 2011) because they cover shorter spans of time than "long chronologies" of the same phenomena, are based on careful selection and AMS ${ }^{14} \mathrm{C}$ measurement of short-lived, pretreated species that minimizes the difference between the dated and target events. This approach can be differentiated from simple "dating," which might include no particular strategy to help ensure greater chronometric precision, and "high precision" dating, which we see as efforts that begin with the kind of sample selection and treatment we use but that also employ appropriate statistical manipulation, such as Bayesian statistics, of constrained data 
Table 2. XAD-purified bison dates by lab number and provenience and stable isotope measurements discussed in this study. All dates are calibrated using IntCal13 (Reimer et al. 2013) (from Lohse et al. 2014b:Table 2).

\begin{tabular}{|c|c|c|c|c|c|c|}
\hline $\begin{array}{l}\text { UCIAMS } \\
\text { Number }\end{array}$ & Provenience & $\begin{array}{l}\text { C:N } \\
\text { Ratio }\end{array}$ & ${ }^{14} \mathrm{C}$ Age & $\begin{array}{l}\text { delta }^{15} \\
\mathrm{~N}\end{array}$ & delta ${ }^{13} \mathrm{C}$ & $2 \sigma$ calibrated range (cal BP) \\
\hline 29246 & $\begin{array}{l}\text { 41VT141, Area B, } \\
\text { N376, E826, level } 10\end{array}$ & 3.26 & $190 \pm 20$ & 5.5 & -7.8 & $290-265$ (19.6\%), 215-145 (52.9\%) \\
\hline 81005 & $\begin{array}{l}\text { 41HY165, Unit 2, } \\
\text { level } 7\end{array}$ & 3.16 & $215 \pm 15$ & 8.6 & -11.1 & $300-275(34.5 \%), 175-150(50.2 \%)$ \\
\hline 81002 & $\begin{array}{l}\text { 41HY165, Unit 2, } \\
\text { level } 2\end{array}$ & 3.14 & $250 \pm 15$ & 8.9 & -9.4 & $310-285$ (86.7\%), 165-155 (8.7\%) \\
\hline 87921 & $\begin{array}{l}\text { 41HY160, Unit } 4 \text {, } \\
\text { level } 3\end{array}$ & 3.16 & $275 \pm 15$ & 6.9 & -14.3 & $425-395$ (27.6\%), 320-290 (67.8\%) \\
\hline 106463 & $\begin{array}{l}\text { 41HY160, Unit } 3 \text {, } \\
\text { level } 5\end{array}$ & 3.03 & $515 \pm 15$ & 6.72 & -11.51 & $545-515$ \\
\hline 129247 & $\begin{array}{l}\text { 41VT141, Area 5(B), } \\
\text { N376, E826, Feature } \\
\text { 2, level } 10\end{array}$ & 3.26 & $515 \pm 15$ & 5.5 & -7.8 & $545-515$ \\
\hline 81003 & $\begin{array}{l}\text { 41HY165, Unit } 2 \text {, } \\
\text { level } 3\end{array}$ & 3.14 & $520 \pm 15$ & 5.3 & -9.0 & $545-515$ \\
\hline 80131 & $\begin{array}{l}\text { 41HY165, Unit } 7 \text {, } \\
\text { level } 2\end{array}$ & 3.16 & $535 \pm 20$ & 6.2 & -9.8 & $625-605(11.8 \%), 555-515$ (83.6\%) \\
\hline 87940 & $\begin{array}{l}\text { 41HY188, Unit } 35 \\
\text { SE, level } 5\end{array}$ & 3.16 & $535 \pm 15$ & 5.9 & -8.7 & $620-610(4.6 \%), 555-520(90.8 \%)$ \\
\hline 87929 & $\begin{array}{l}\text { 41HY188, Unit } 4 \text {, } \\
\text { level } 5\end{array}$ & 3.21 & $540 \pm 15$ & 5.7 & -9.4 & $620-610(10.0 \%), 555-520(85.4 \%)$ \\
\hline 87926 & $\begin{array}{l}\text { 41HY188, Unit } 1 \mathrm{NE} \text {, } \\
\text { level } 4\end{array}$ & 3.21 & $545 \pm 15$ & 6.4 & -10.8 & $625-605(17.5 \%), 560-525$ (77.9\%) \\
\hline 87932 & $\begin{array}{l}\text { 41HY188, Unit } 11 \\
\mathrm{NE} \text {, level } 4\end{array}$ & 3.17 & $545 \pm 15$ & 6.1 & -9.6 & $625-605(17.5 \%), 560-525$ (77.9\%) \\
\hline 87928 & $\begin{array}{l}\text { 41HY188, Unit } 4 \text { NW, } \\
\text { level } 3\end{array}$ & 3.19 & $545 \pm 15$ & 7.9 & -10.2 & $625-605(17.5 \%), 560-525$ (77.9\%) \\
\hline 87937 & $\begin{array}{l}\text { 41HY188, Unit } 22 \\
\text { SW, level } 11\end{array}$ & 3.19 & $545 \pm 15$ & 6.2 & -9.3 & $625-605(17.5 \%), 560-525$ (77.9\%) \\
\hline 81007 & $\begin{array}{l}\text { 41HY165, Unit 11, } \\
\text { level } 3\end{array}$ & 3.15 & $555 \pm 15$ & 6.7 & -8.9 & $630-600(34.7 \%), 560-530(60.7 \%)$ \\
\hline
\end{tabular}




\begin{tabular}{|c|c|c|c|c|c|c|}
\hline $\begin{array}{l}\text { UCIAMS } \\
\text { Number }\end{array}$ & Provenience & $\begin{array}{l}\text { C:N } \\
\text { Ratio }\end{array}$ & ${ }^{14} \mathrm{C}$ Age & $\begin{array}{l}\text { delta }{ }^{15} \\
\text { N }\end{array}$ & delta ${ }^{13} \mathrm{C}$ & $2 \sigma$ calibrated range (cal BP) \\
\hline 87930 & $\begin{array}{l}\text { 41HY188, Unit } 6 \mathrm{NE}, \\
\text { level } 8\end{array}$ & 3.15 & $555 \pm 15$ & 8.4 & -10.5 & $630-600(34.7 \%), 560-530(60.7 \%)$ \\
\hline 111183 & $\begin{array}{l}\text { 41ME147, N807 } \\
\text { E629, level } 3\end{array}$ & 3.07 & $560 \pm 15$ & 5.5 & -8.6 & $630-600(42.7 \%), 560-530(52.7 \%)$ \\
\hline 80133 & $\begin{array}{l}\text { 41HY165, Unit } 7 \text {, } \\
\text { level } 4\end{array}$ & 3.11 & $565 \pm 20$ & 4.6 & -7.3 & $635-595(51.8 \%), 560-530(43.6 \%)$ \\
\hline 87927 & $\begin{array}{l}\text { 41HY188, Unit } 2 \text { SW, } \\
\text { level } 3\end{array}$ & 3.19 & $570 \pm 15$ & 5.9 & -10.2 & $635-595$ (56.1\%), 560-535 (39.3\%) \\
\hline 80132 & $\begin{array}{l}\text { 41HY165, Unit 2, } \\
\text { level } 4\end{array}$ & 3.12 & $575 \pm 20$ & 5.1 & -9.6 & $640-590(61.2 \%), 565-535(34.2 \%)$ \\
\hline 87935 & $\begin{array}{l}\text { 41HY188, Unit } 22 \\
\text { SE, level } 5\end{array}$ & 3.21 & $580 \pm 15$ & 6.1 & -10.9 & $635-590(65.4 \%), 565-540(30.0 \%)$ \\
\hline 87931 & $\begin{array}{l}\text { 41HY188, Unit } 7 \\
\text { NW/NE, level } 3\end{array}$ & 3.19 & $580 \pm 15$ & 6.7 & -10.2 & $635-590(65.4 \%), 565-540(30.0 \%)$ \\
\hline 87936 & $\begin{array}{l}\text { 41HY188, Unit } 22 \\
\mathrm{NE} \text {, level } 10\end{array}$ & 3.23 & $585 \pm 15$ & 6.1 & -9.7 & $640-590(68.5 \%), 565-540(26.9 \%)$ \\
\hline 87933 & $\begin{array}{l}\text { 41HY188, Unit } 11 \\
\mathrm{NE} \text {, level } 5\end{array}$ & 3.21 & $595 \pm 15$ & 5.9 & -10.2 & $645-585(73.6 \%), 565-545(21.8 \%)$ \\
\hline 80134 & $\begin{array}{l}\text { 41HY165, Unit 11, } \\
\text { level } 7\end{array}$ & 3.12 & $2205 \pm 20$ & 6.6 & -8.5 & $2310-2150$ \\
\hline 80137 & $\begin{array}{l}\text { 41HY160, Unit 10, } \\
\text { level } 7\end{array}$ & 3.13 & $2210 \pm 20$ & 5.7 & -7.6 & $2310-2155$ \\
\hline 80135 & $\begin{array}{l}\text { 41HY160, Unit 13, } \\
\text { level } 5\end{array}$ & 3.12 & $2255 \pm 20$ & 5.5 & -8.4 & $\begin{array}{l}2345-2305(41.3 \%), 2245-2180 \\
(51.4 \%), 2170-2160(2.7 \%)\end{array}$ \\
\hline 87925 & $\begin{array}{l}\text { 41HY160, Unit } 23 \\
\text { SE, level } 10\end{array}$ & 3.19 & $2270 \pm 15$ & 5.2 & -8.6 & $\begin{array}{l}\text { 2345-2305 (73.1\%), 2235-2185 } \\
(22.3 \%)\end{array}$ \\
\hline 87922 & $\begin{array}{l}\text { 41HY160, Unit 4, } \\
\text { level } 8\end{array}$ & 3.26 & $2275 \pm 15$ & 5.0 & -9.3 & $\begin{array}{l}2350-2305(82.4 \%), 2230-2205 \\
(12.3 \%), 2195-2190(0.7 \%)\end{array}$ \\
\hline 106470 & $\begin{array}{l}\text { 41HY160, Unit } 3 \text {, } \\
\text { level } 14\end{array}$ & 3.04 & $2415 \pm 20$ & 7.4 & -14.5 & $\begin{array}{l}2680-2665(2.1 \%), 2655-2645 \\
(2.5 \%), 2490-2355(90.8 \%)\end{array}$ \\
\hline 87920 & $\begin{array}{l}\text { 41HY160, Unit } 1 \\
\text { level } 2\end{array}$ & 3.21 & $2460 \pm 15$ & 6.0 & -8.2 & $\begin{array}{l}2705-2630(41.5 \%), 2620-2560 \\
(20.3 \%), 2545-2430(32.8 \%), 2390- \\
2385(0.8 \%)\end{array}$ \\
\hline 81004 & $\begin{array}{l}\text { 41HY165, Unit } 3 \text {, } \\
\text { level } 8\end{array}$ & 3.29 & $2460 \pm 25$ & 5.1 & -9.0 & $\begin{array}{l}2705-2630(31.8 \%), 2620-2380 \\
(63.6 \%)\end{array}$ \\
\hline
\end{tabular}




\begin{tabular}{|c|c|c|c|c|c|c|}
\hline $\begin{array}{l}\text { UCIAMS } \\
\text { Number }\end{array}$ & Provenience & $\begin{array}{l}\text { C:N } \\
\text { Ratio }\end{array}$ & ${ }^{14} \mathrm{C}$ Age & $\begin{array}{l}\text { delta }{ }^{15} \\
\mathrm{~N}\end{array}$ & delta ${ }^{13} \mathrm{C}$ & $2 \sigma$ calibrated range (cal BP) \\
\hline 87938 & $\begin{array}{l}\text { 41HY188, Unit } 23 \\
\text { SE, level } 8\end{array}$ & 3.22 & $2470 \pm 15$ & 6.3 & -8.6 & $\begin{array}{l}2705-2630(37.9 \%), 2620-2465 \\
(57.5 \%)\end{array}$ \\
\hline 87923 & $\begin{array}{l}\text { 41HY160, Unit } 6 \\
\text { level } 10\end{array}$ & 3.20 & $2470 \pm 15$ & 5.6 & -8.9 & $\begin{array}{l}2705-2630(37.9 \%), 2620-2465 \\
(57.5 \%)\end{array}$ \\
\hline 81006 & $\begin{array}{l}\text { 41HY165, Unit } 3 \text {, } \\
\text { level } 6\end{array}$ & 3.18 & $2475 \pm 15$ & 5.9 & -8.1 & $2710-2485$ \\
\hline 106465 & $\begin{array}{l}\text { 41HY160, Unit } 3 \text {, } \\
\text { level } 6\end{array}$ & 3.05 & $2475 \pm 20$ & 5.3 & -8.05 & $2715-2465$ \\
\hline 87924 & $\begin{array}{l}\text { 41HY160, Unit } 6 \\
\text { level } 11\end{array}$ & 3.18 & $2480 \pm 15$ & 5.1 & -8.4 & $2710-2490$ \\
\hline 87934 & $\begin{array}{l}\text { 41HY188, Unit 20, } \\
\text { level } 12\end{array}$ & 3.21 & $2480 \pm 15$ & 5.6 & -8.4 & $2710-2490$ \\
\hline 106464 & $\begin{array}{l}\text { 41HY160, Unit } 3 \text {, } \\
\text { Level } 6\end{array}$ & 3.08 & $2480 \pm 15$ & 5.41 & -9.19 & $2710-2490$ \\
\hline 106471 & $\begin{array}{l}\text { 41HY160, Unit } 4, \\
\text { level } 7\end{array}$ & 3.07 & $2490 \pm 20$ & 6.57 & -9.25 & $\begin{array}{l}2720-2650(21.8 \%), 2645-2490 \\
(73.6 \%)\end{array}$ \\
\hline 80138 & $\begin{array}{l}\text { 41HY160, Unit 13, } \\
\text { level } 13\end{array}$ & 3.11 & $2955 \pm 20$ & 5.5 & -7.8 & $\begin{array}{l}3210-3200(1.1 \%), 3180-3060 \\
(93.0 \%), 3050-3040(1.2 \%)\end{array}$ \\
\hline 80130 & $\begin{array}{l}\text { 41HY165, Unit } 8 \\
\text { level } 11\end{array}$ & 3.15 & $2965 \pm 20$ & 5.1 & -8.4 & $\begin{array}{l}3210-3190(4.4 \%), 3185-3065 \\
(91.0 \%)\end{array}$ \\
\hline 80140 & $\begin{array}{l}\text { 41HY160, Unit 13, } \\
\text { level } 13\end{array}$ & 3.12 & $2985 \pm 20$ & 5.4 & -9.5 & $3225-3075$ \\
\hline 87939 & $\begin{array}{l}\text { 41HY188, Unit 25, } \\
\text { level } 14\end{array}$ & 3.24 & $2995 \pm 15$ & 5.2 & 9.3 & $\begin{array}{l}3230-3140(88.2 \%), 3130-3115 \\
(2.8 \%), 3095-3080(4.3 \%)\end{array}$ \\
\hline 80129 & $\begin{array}{l}\text { 41HY165, Unit } 3 \\
\text { level } 7\end{array}$ & 3.12 & $3000 \pm 20$ & 5.6 & -7.8 & $\begin{array}{l}3320-3310(1.7 \%), 3240-3140 \\
(85.4 \%), 3130-3110(3.8 \%), 3095- \\
3080(4.4 \%)\end{array}$ \\
\hline 106472 & $\begin{array}{l}\text { 41HY160, Unit } 4, \\
\text { level } 7\end{array}$ & 3.11 & $3000 \pm 20$ & 7.18 & -8.77 & $\begin{array}{l}3320-3310(1.7 \%), 3240-3140 \\
(85.4 \%), 3130-3110(3.8 \%), 3095- \\
3080(4.4 \%)\end{array}$ \\
\hline 129245 & $\begin{array}{l}\text { 41BL323, N1161, } \\
\text { E1081, 94.4-94.37 } \\
\text { elevation }\end{array}$ & 3.32 & $3000 \pm 15$ & 5.6 & -8.3 & $\begin{array}{l}3235-3140(91.6 \%), 3125-3115 \\
(1.3 \%), 3095-3080(2.5 \%)\end{array}$ \\
\hline 95718 & $\begin{array}{l}\text { 41HY165, Unit } 11 \\
\text { level } 10\end{array}$ & 3.24 & $3065 \pm 15$ & 4.9 & -20.0 & $3350-3225$ \\
\hline
\end{tabular}




\begin{tabular}{|c|c|c|c|c|c|c|}
\hline $\begin{array}{l}\text { UCIAMS } \\
\text { Number }\end{array}$ & Provenience & $\begin{array}{l}\text { C:N } \\
\text { Ratio }\end{array}$ & ${ }^{14} \mathrm{C}$ Age & $\begin{array}{l}\text { delta }^{15} \\
\text { N }\end{array}$ & delta ${ }^{13} \mathrm{C}$ & $2 \sigma$ calibrated range (cal BP) \\
\hline 80999 & $\begin{array}{l}\text { 41HY160, Unit } 9 \text {, } \\
\text { level } 14\end{array}$ & $\begin{array}{l}\text { Too } \\
\text { small }\end{array}$ & $5060 \pm 40$ & - & - & $5910-5715$ \\
\hline 95717 & $\begin{array}{l}\text { 41HY160, Unit 14, } \\
\text { level } 13\end{array}$ & 3.21 & $5110 \pm 15$ & 8.1 & -10.7 & $\begin{array}{l}5915-5885(47.2 \%), 5820-5760 \\
(48.2 \%)\end{array}$ \\
\hline 80139 & $\begin{array}{l}\text { 41HY160, Unit } 7 \\
\text { level } 14\end{array}$ & 3.14 & $5115 \pm 20$ & 6.8 & -9.8 & $\begin{array}{l}5920-5880(48.4 \%), 5825-5755 \\
(47.0 \%)\end{array}$ \\
\hline 80136 & $\begin{array}{l}\text { 41HY160, Unit } 7 \\
\text { level } 15\end{array}$ & 3.15 & $5120 \pm 20$ & 9.3 & -9.6 & $\begin{array}{l}5925-5885(56.4 \%), 5820-5760 \\
(39.0 \%)\end{array}$ \\
\hline 80998 & $\begin{array}{l}\text { 41HY160, Unit } 7 \\
\text { level } 14\end{array}$ & 3.13 & $5120 \pm 20$ & 8.5 & -10.5 & $\begin{array}{l}5925-3935(56.4 \%), 5820-5760 \\
(39.0 \%)\end{array}$ \\
\hline 129248 & $\begin{array}{l}\text { 41WM267, Area D, } \\
\text { E-6, level 120-121, } \\
\text { 93.3-93.2 elevation }\end{array}$ & 3.28 & $5135 \pm 20$ & 5.7 & -8.6 & $\begin{array}{l}5935-5890(81.4 \%), 5810-5765 \\
(14.0 \%)\end{array}$ \\
\hline 106473 & $\begin{array}{l}\text { 41HY160, Unit 13, } \\
\text { level } 13\end{array}$ & 3.14 & $5140 \pm 20$ & 9.38 & -11.9 & $\begin{array}{l}5935-5890(87.3 \%), 5805-5770 \\
(8.1 \%)\end{array}$ \\
\hline 106468 & $\begin{array}{l}\text { 41HY160, Unit } 3 \text {, } \\
\text { level } 14\end{array}$ & 3.11 & $5140 \pm 20$ & 7.43 & -19.0 & $\begin{array}{l}5935-5890(87.3 \%), 5805-5770 \\
(8.1 \%)\end{array}$ \\
\hline 106469 & $\begin{array}{l}\text { 41HY160, Unit } 3 \\
\text { level } 14\end{array}$ & 3.17 & $5145 \pm 20$ & 9.59 & -11.9 & $\begin{array}{l}5940-5890(91.3 \%), 5805-5795 \\
(1.8 \%), 5785-5770(2.3 \%)\end{array}$ \\
\hline 81000 & $\begin{array}{l}\text { 41HY160, Unit 16, } \\
\text { level } 13\end{array}$ & 3.25 & $5155 \pm 15$ & 8.7 & -11.1 & $5935-5900$ \\
\hline 81001 & $\begin{array}{l}\text { 41HY160, Unit 16, } \\
\text { level } 13\end{array}$ & 3.19 & $5165 \pm 15$ & 8.3 & -11.5 & $\begin{array}{l}5980-5980(1.8 \%), 5940-5905 \\
(93.6 \%)\end{array}$ \\
\hline 80997 & $\begin{array}{l}\text { 41HY160, Unit } 7 \\
\text { level } 9\end{array}$ & 3.12 & $5180 \pm 15$ & 8.5 & -9.4 & $\begin{array}{l}5990-5970(16.4 \%), 5945-5910 \\
(79.0 \%)\end{array}$ \\
\hline 111182 & $\begin{array}{l}\text { 41ME147, N802 } \\
\text { E631, level } 4\end{array}$ & 3.46 & $5205 \pm 20$ & 3.6 & -16.7 & $5990-5920$ \\
\hline
\end{tabular}

to construct or build chronological models characterized by greatly reduced age range probabilities. While this study focuses on precisely dating bison, we include an example of high-precision chronology, below, based on our work with the Calf Creek archeological component at Spring Lake.

\section{RADIOCARBON RESULTS}

Prehistoric bison exploitation is dated to four main periods in our study area, the first lasting from ca. 5955-5815 cal B.P.; the second and third involving two pulses between 3295-3130 cal B.P. and 
2700-2150 cal B.P. separated by a 400+ year hiatus from ca. 3130 to 2700 cal B.P.; and the fourth consisting of a short Late Prehistoric interval from 650 to $530 \mathrm{cal}$ B.P (Figure 3). Four historic period dates range from approximately $400-150 \mathrm{cal}$ B.P. This last interval is hard to date precisely because of variations in atmospheric radiocarbon concentration during this period. However, historic documents record widespread bison hunting across Texas and nearby regions (e.g., Speth 2004; Wade 2003), and this period is critical for understanding regional culture historical events for the preceding three or four centuries. The prehistoric periods include the widespread Calf Creek horizon, found across the Southern Plains (Thurmond and Wyckoff 1999); two different periods in the regional Late Archaic (termed Late Archaic Bison 1 and Late Archaic Bison 2, $\mathrm{LA}_{\mathrm{B}} 1$ and $\mathrm{LA}_{\mathrm{B}} 2$, to distinguish these bison periods from subdivisions in the regional chronology); and what appears to be an early facet of the Toyah phase or horizon (Kenmotsu and Boyd 2012).

Calf Creek ( $n=13)$

LAB1 $(n=8)$

$\operatorname{LAB2}(\mathrm{n}=16)$

Toyah $(n=20)$
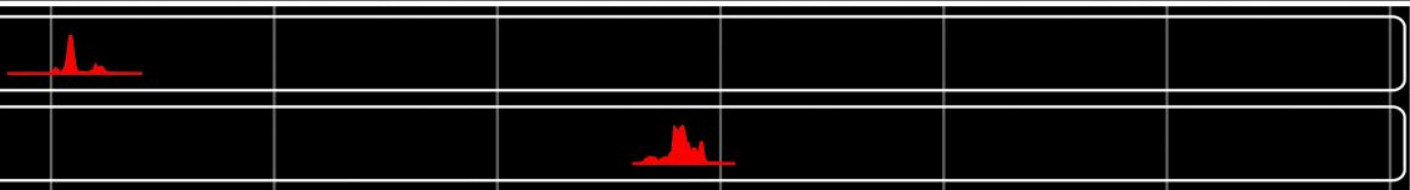

Historic $(n=4)$

Historic $(n=4)$
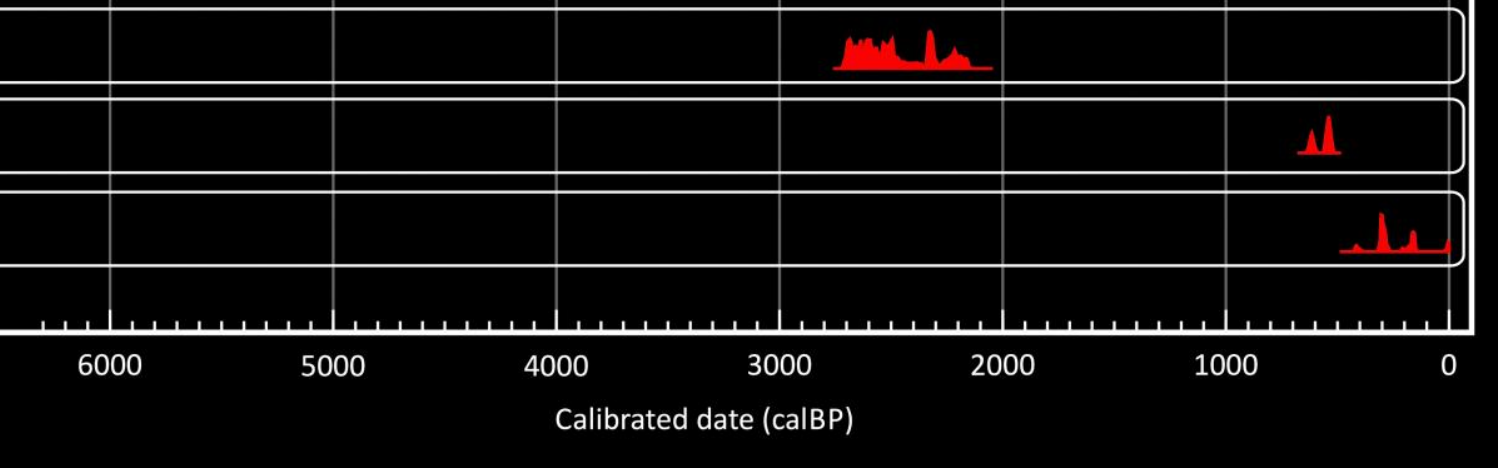

Figure 3. Summed probabilities for 61 XAD-purified AMS dates on bison bone from archeological contexts in Central and South Texas.

Calf Creek: ca. 5955-5815 cal B.P.

The earliest period of bison presence in our study is associated with the Calf Creek horizon. This period, which marks the end of the Early Archaic in Central Texas (Lohse et al. 2014a), is defined by the widespread occurrence of distinctive basally notched Bell and Andice points (Figure 4) often found in direct association with bison. Calf Creek materials are reported across Oklahoma (Bement et al. 2005; Duncan 1996; Neal 1999; Neal and Duncan 1998; Thurmond and Wyckoff 1999; Wyckoff 1994, 1995; Wyckoff et al. 2009); Central and South Texas, the Trans Pecos, and northern Tamaulipas (Calame et al. 2002; Collins 1994; Gray 2013; McReynolds 2002; Prewitt 1983; Ricklis 1988; Ross 1965; Sorrow et al. 1967; Walter 2013); western Arkansas (Dickson 1970); and into eastern New Mexico (Carmichael 1986). They are also present but less well documented in eastern Colorado, Missouri (O’Brien and Wood 1998), and Kansas (Stites 2006). Two Calf Creek points have recently been reported as far north as southern Utah (Wyckoff and Richens 2010). The brevity of this period has made it difficult to date these deposits with any precision. For example, this horizon is not 
represented in Dillehay's (1974) model for the Southern Plains (see Table 1), and is only poorly resolved at many sites (e.g., Wilson-Leonard). Stable carbon and nitrogen isotope data from samples in this study indicate that Calf Creek climates were among the coldest and perhaps driest experienced in the entire Holocene (Lohse et al. 2014b).

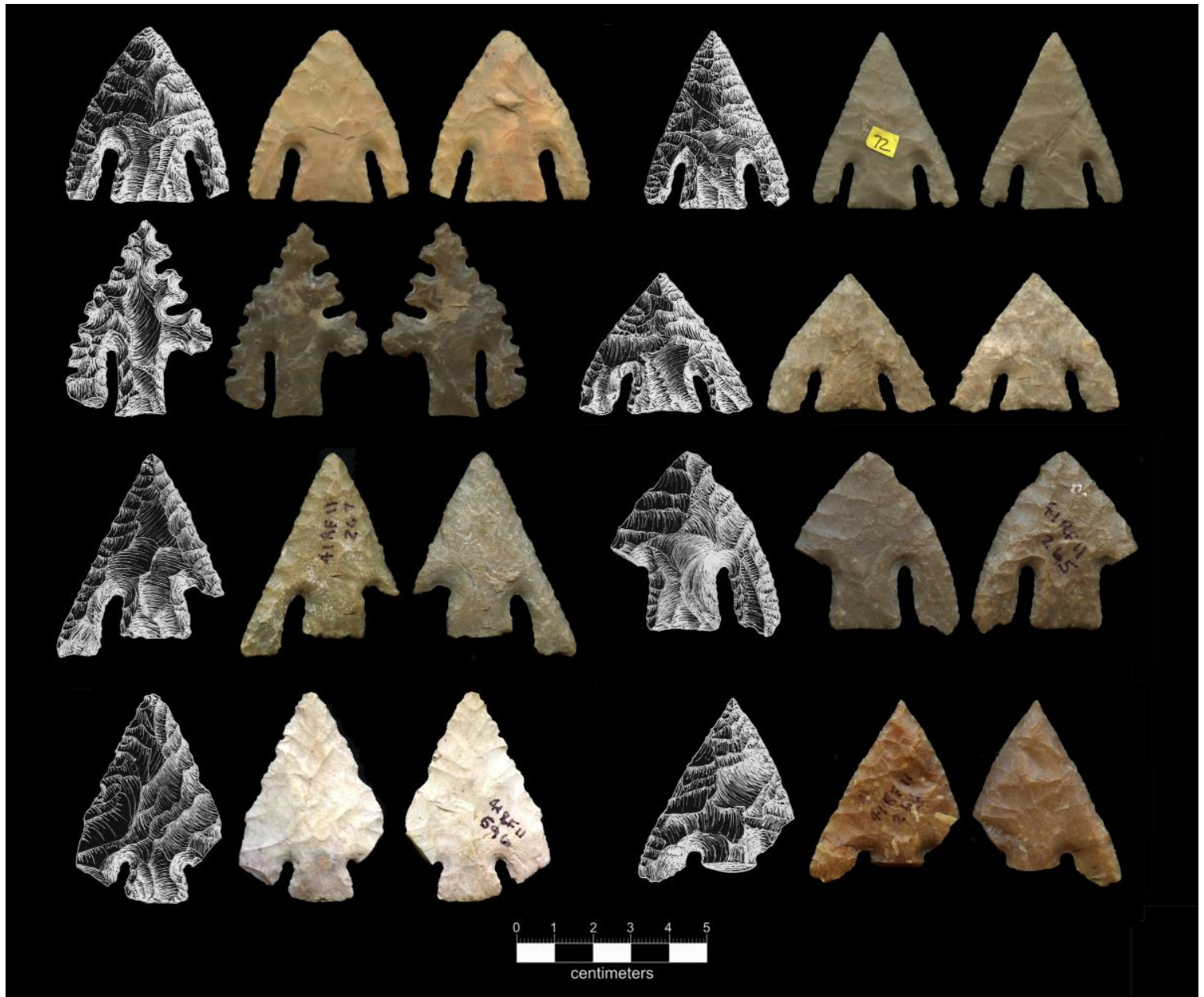

Figure 4. Examples of basally notched Calf Creek horizon points (Bell type). Top two rows are from Zapata County in South Texas (courtesy of Richard McReynolds). Bottom two rows are from the Hopper's Landing site (41RF11) (courtesy of the Museum of the Coastal Bend). All line drawings by Richard McReynolds.

Our Calf Creek bison data derive from three sites: Spring Lake (41HY160), Eagle Bluff, and Cervenka; the latter two have only a single date each. A bison bone sample associated with a Bell point from Feature 2 at the Landslide site (41BL85; Sorrow et al. 1967) was curated at the Texas Archeological Research Laboratory and was submitted for dating as part of this study, but did not yield enough collagen to be reliably measured. Two separate contexts at Spring Lake, over $40 \mathrm{~m}$ apart, have yielded Calf Creek remains including 11 AMS dates on bison (Lohse et al. 2013). Conservatively, the 13 dates together span the interval from 5990-5715 cal B.P., taking the extreme 2 sigma ranges for the earliest and latest dates. However, most dates fall onto an ideal part of the calibration curve, centering around $5900 \mathrm{cal}$ B.P., between a modest reversal at about $5960 \mathrm{cal}$ B.P. and a minor plateau spanning from approximately 5850-5770 cal B.P. (Figure 5). The effect of these two parts of the curve is to draw out or extend the calibrated probabilities of the earliest and last dates. 
However, the difference of the earliest and latest dates allows us to estimate the duration of the Calf Creek components to be between 25 and 260 calibrated years (mean=140 cal years).

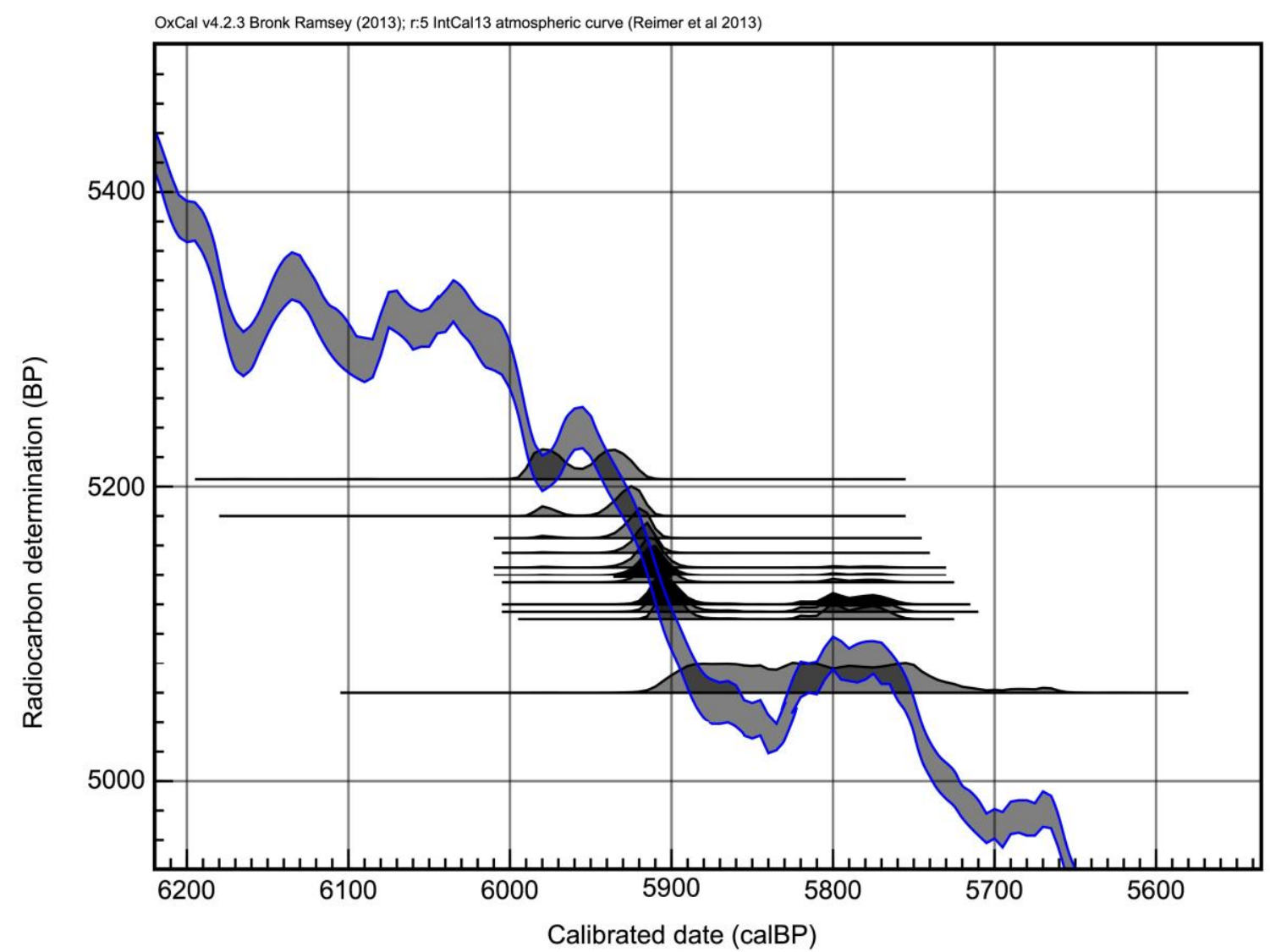

Figure 5. Calibrated probabilities for 13 Calf Creek dates superimposed on IntCal13 calibration curve.

Radiocarbon dates reported in association with Calf Creek materials commonly span over seven hundred years (see Wyckoff et al. 2009), and some "long" chronologies ascribe as much as a thousand years to this period (e.g., Collins 2004). Based on our results, however, we argue that this horizon may have been considerably shorter in duration. A moderately conservative treatment of these dates suggests a period of about 140 years. However, Bayesian modeling of the calibrated dates from Spring Lake suggests the presence of bison during a very short interval of no more than about 40 years (Figure 6), from 5937-5897 cal B.P. $\left(\mathrm{A}_{\text {model }}=122.3\right.$ ). This model indicates the short duration that can be identified with calibrated radiocarbon dates under ideal circumstances and with high-density sampling. The single date from Eagle Bluff is slightly earlier than this range, indicating regional variation in terms of timing and age of different site components. This model substantially narrows the overall age span for Calf Creek, and creates an opportunity to develop and test hypotheses relating to the overall chronology of bison movements and cultural responses during this period. 


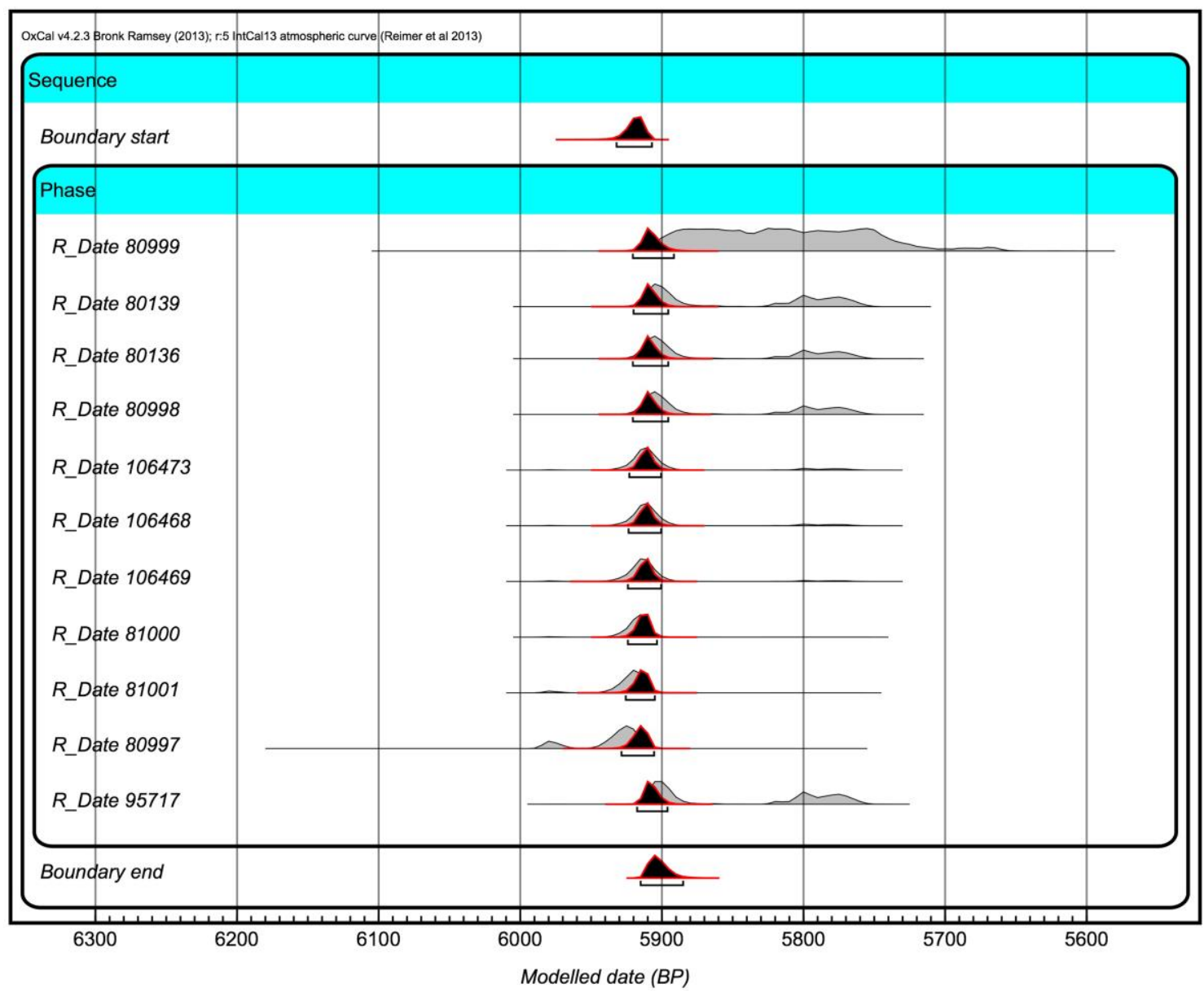

Figure 6. Simple Bayesian phase model of $\mathrm{AMS}{ }^{14} \mathrm{C}$ from Calf Creek deposits at Spring Lake. These data suggest that the occupation during this horizon may have been limited to only a single event or a few rapid visitations.

Other than our data, very few precise assays are available for this time period. A Calf Creek point embedded in a juvenile bison (B. occidentalis) skull found in river gravels near Tulsa, Oklahoma (Bement et al. 2005) and dated at $5120 \pm 20{ }^{14} \mathrm{C}$ years B.P. (approximately 5925-5760 cal B.P.) falls squarely within the range of dates we report. The Calf Creek component at the Kubik site, also in Oklahoma, has produced three dates: $4990 \pm 100$ (NZA6601) (5950-5465 cal B.P.), $5020 \pm 120$ (NZA6602), and $5050 \pm 60$ (Beta 98146) radiocarbon years B.P. (Neal 1999). The latter two dates, from a split nut hull, average to about 5895-5735 cal B.P. All three partially overlap with but are generally younger than our bison dates by a couple of centuries. The large 2 sigma probabilities of the Kubik dates relate to their large standard deviations compared with samples in our study, and also partly to a reversal in the calibration curve that occurs at ca. $5800 \mathrm{cal}$ B.P. (see Figure 5). However, the nutshell dates are considered highly reliable, and the Kubik data suggest that the Calf Creek horizon extended later in Oklahoma than in our study area. Additional sampling using precision dating protocols will be necessary to define the temporal extent of the Calf Creek horizon as it occurred elsewhere on the Southern Plains. 


\section{Late Archaic: ca. $3295-3130$ and 2700-2150 cal B.P.}

Following Calf Creek, bison appear to have been absent from the landscape for more than two thousand years, from ca. 5750-3300 cal B.P. Regional models (see Table 1) show bison throughout the Late Archaic, but are vague about when they appear and tend to treat the Late Archaic as a single undifferentiated period. Single component sites with bison dating to this time are uncommon. Most sites, like Wilson-Leonard, have mixed or compressed Late Archaic components. Our Late Archaic bison dates come from four sites: two Spring Lake sites (41HY160 and 41HY165), 41HY188, and Gault.

Our data suggest that Late Archaic bison exploitation took place over two distinct intervals. The first period $\left(\mathrm{LA}_{\mathrm{B}} 1\right.$ ) began by $3295 \mathrm{cal}$ B.P. (mean of 3355-3220 cal B.P., UCIAMS-95718) and continued until approximately 3130 cal B.P. (mean of 3215-3005 cal B.P., UCIAMS-80138). The duration of the period is estimated at between 55 and $270 \mathrm{cal}$ years, with a mean of $165 \mathrm{cal}$ years. This bison pulse is followed by a hiatus of at least 400 years (the 2 sigma difference is $380-700$ cal years) after which a subsequent pulse, $\mathrm{LA}_{\mathrm{B}} 2$, lasts from about 2700-2150 cal B.P. The more than 400 year hiatus after $3130 \mathrm{cal}$ B.P. is previously unreported, likely as a result of the reliance on archeological associations for reconstructing cultural patterns (Figure 7). Stable carbon and nitrogen isotope data indicate that Late Archaic climates were relatively stable for the entire $\mathrm{LA}_{\mathrm{B}} 1$ and $\mathrm{LA}_{\mathrm{B}} 2$ periods, and that both periods were somewhat warmer and had more effective moisture than the earlier Calf Creek or later Toyah periods (Lohse et al. 2014b). However, both also correspond with a period of globally cool climates (Wanner et al. 2011). Importantly, Viau et al. (2006) identify the period around 3000 B.P., approximately the middle of our postulated hiatus, as among the warmest of the entire North American Holocene and van Geel et al. (1996) identify a cool, moist period in Europe and North America starting by around 2650 cal B.P. If verified, these temperature changes could help explain or contextualize bison movements into and out of the study area at different times during the Late Archaic period.

Although there appears to be a gap in bison exploitation in $\mathrm{LA}_{\mathrm{B}} 2$ between ca. 2275 and $2415{ }^{14} \mathrm{C}$ B.P. (see Table 2), this gap is likely an artifact of the calibration curve. A plateau in the curve occurs during $\mathrm{LA}_{B} 2$, followed by a steep decline and then another mild reversal. These statistical plateaus affect the interpretation of radiocarbon data most obviously by creating very broad calibrated distributions for the dates in these groups. Indeed, the estimated length of $\mathrm{LA}_{\mathrm{B}} 2$ (200-550 cal years) is the longest in our study, and it is possible that the duration of this period is overestimated because of fluctuations in the calibration curve during this interval.

A less obvious effect of the plateaus and associated steep segments of the curve is that even with precise measurements and very dense sampling, conventional ages corresponding to plateaus will be overrepresented, and those during steep sections may tend to be underrepresented (Calf Creek is an 


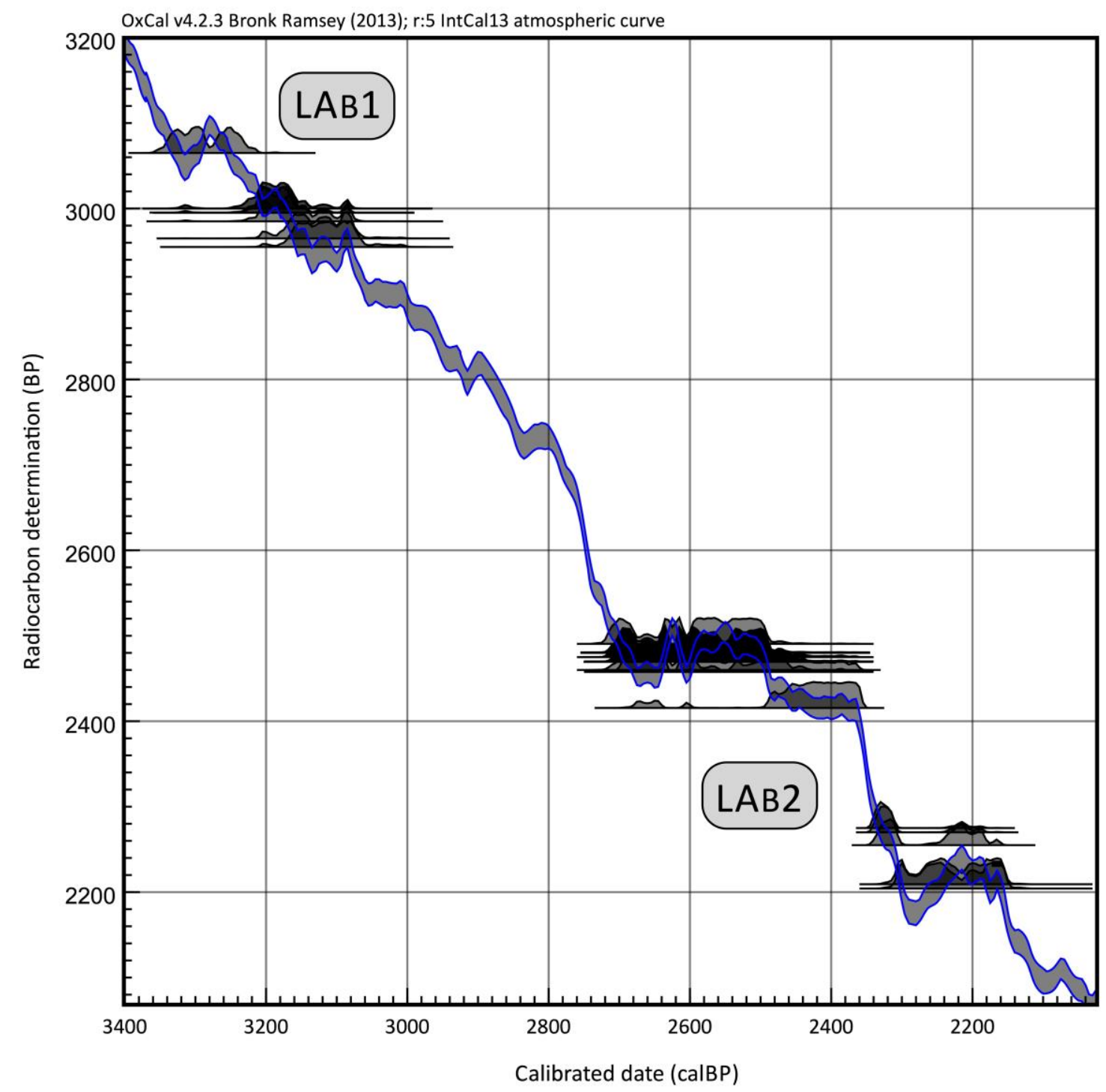

Figure 7. Calibrated probability distributions for 24 Late Archaic AMS ${ }^{14} \mathrm{C}$ bison dates. The $L A_{B} 2$ occupies a relatively flat part of the curve from about 2700-2360 cal B.P., which contributes to temporal imprecision during this interval. The steep decline following this plateau creates the appearance that a brief hiatus separates this period from a third Late Archaic period of bison exploitation.

exception; see Figure 5). This phenomenon can be modeled with OxCal using the $R \_$Simulate command, which produces a conventional age from a calendar age with a given measurement error, and then calibrates it. To better understand the effect of the curve on our calibrated sample, we simulated a group of 170 dates (10 dates every 25 years) from 2500 to 2100 cal B.P. assuming a measurement precision of $\pm 20{ }^{14} \mathrm{C}$ years to mirror the precision of our study. This very dense dataset is analogous to recovering and dating 40 bison per century from the archeological record, or roughly 10 times what we have sampled for the period. Plotting the frequency of conventional ages demonstrates that even at this density, conventional ages from ca. 2380 to $2260 \mathrm{cal}$ B.P. are relatively unlikely (roughly 10-20 percent as likely) to be sampled compared with ages on the plateaus before and after that time (Figure 8). The congruence between the distributions of simulated and observed 
conventional ages through this period suggests that the apparent gap is an artifact of the calibration curve, and that further sampling is unlikely to produce many more conventional ages between 2415 and $2275 \mathrm{ca}$. B.P.

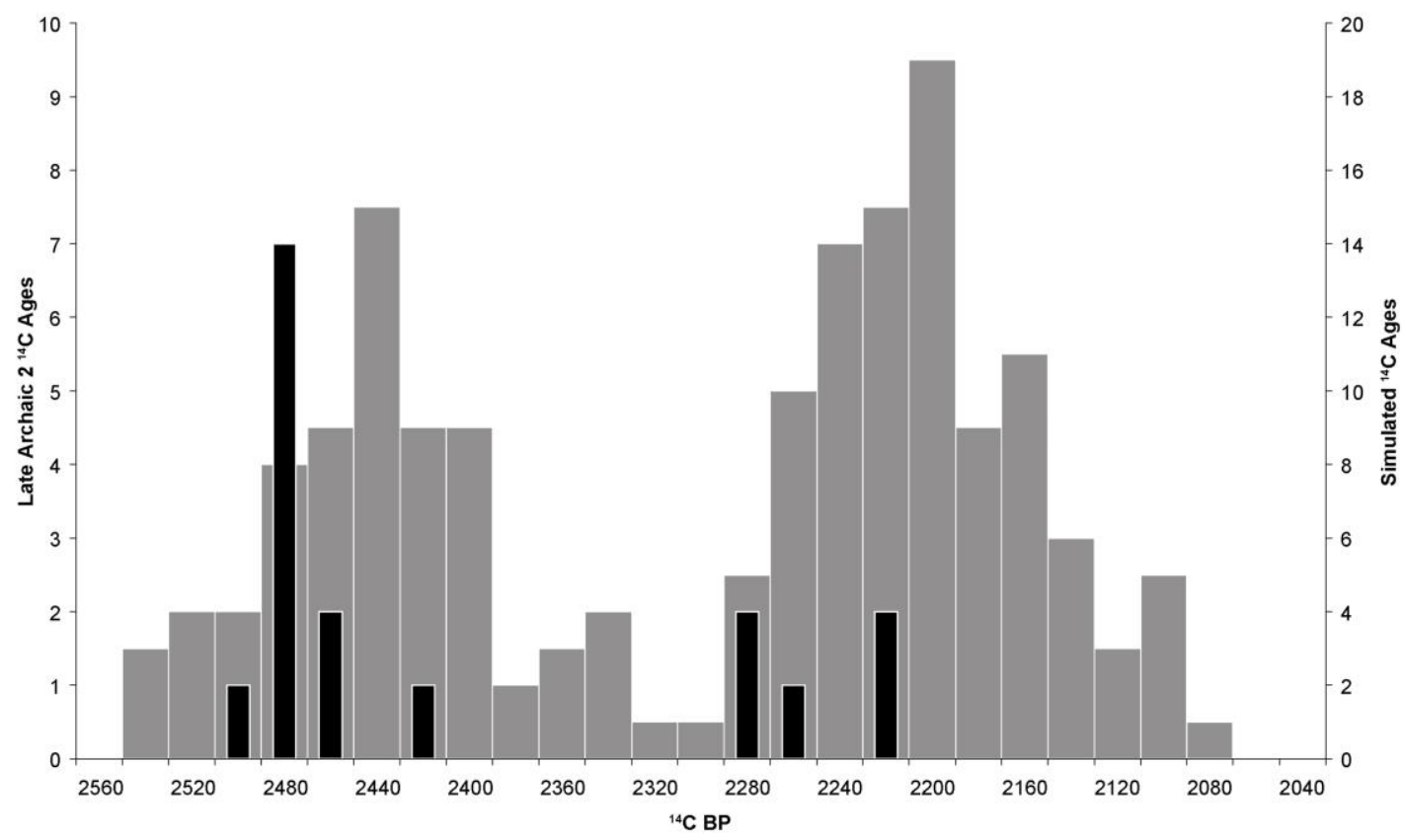

Figure 8. Frequency of simulated ${ }^{14} \mathrm{C}$ ages (gray columns) versus measured ${ }^{14} \mathrm{C}$ ages (black columns) on bison across two plateaus in the Late Archaic from 2500-2100 cal B.P. (2560-2040 14C yr B.P.) and the apparent gap in ${ }^{14} \mathrm{C}$ ages that is an artifact of the calibration curve. Simulated ages were generated in OxCal 4.17 (Bronk Ramsey 2010) using R_Simulate, assuming 10 dates every $25 \mathrm{cal}$ years and a precision of $\pm 20{ }^{14} \mathrm{C} \mathrm{yr}$, comparable to the precision of the dates in this study. The "gap" in $\mathrm{LAB}_{2}{ }^{14} \mathrm{C}$ ages is likely not a true hiatus in bison exploitation.

\section{Toyah: 650-530 cal B.P.}

Following the Late Archaic, bison again appear to have been absent from the study area for approximately 1500 years, until ca. 650 cal B.P. They reappeared suddenly and may have been present for less than $120 \mathrm{cal}$ years before once again disappearing. This Toyah bison interval is the shortest in our study. Climatically, our early Toyah bison period occurred immediately after the onset of the Little Ice Age (LIA), a prolonged cool and dry period, the beginning of which corresponds with one of the largest volcanic events of the entire Holocene as well as severely reduced solar activity (Mayewski et al. 2004; Wanner et al. 2011). Stable carbon and nitrogen isotope data (Lohse et al. 2014b) indicate that temperatures during this brief interval were not as cool as the Calf Creek period, and that effective moisture was slightly greater than in the Calf Creek period. However, the period was still cooler and drier than either $\mathrm{LA}_{\mathrm{B}} 1$ or $\mathrm{LA}_{\mathrm{B}} 2$. The LIA was complex climatologically, and significant variation has been documented within it. Based on over a thousand tree-ring, ice core, coral, sediment, and other proxy records, Mann et al. (2009) reconstruct a brief cold period in the northern hemisphere centering around A.D. 1340 (ca. $610 \mathrm{cal} \mathrm{B.P.)} \mathrm{that} \mathrm{precedes} \mathrm{a} \mathrm{short} \mathrm{warm}$ interval before temperatures decline once again just prior to ca. A.D. 1500 (ca. $450 \mathrm{cal} \mathrm{B.P.).} \mathrm{The}$ reconstructed cool periods correspond with the Wolf and Spöer grand solar minima, respectively 
(Bard et al., 2000; Steinhilber and Beer 2011), brief intervals of reduced solar activity (e.g., sun spots, solar flares, etc.) that are associated with global cooling.

The bimodal calibrated distributions of our 20 dates from this period (Figure 9) partially reflect the shape of the calibration curve during this interval, which exhibits a sharp reversal resulting in paired intercepts for each assay. Taking the difference of the oldest and youngest dates in our Toyah bison period, the period lasted between 10 and $120 \mathrm{cal}$ years, with a mean of $70 \mathrm{cal}$ years. Toyah dates come from five sites: two Spring Lake sites (41HY160 and 41HY165), 41HY188, Eagle Bluff, and McNeill.

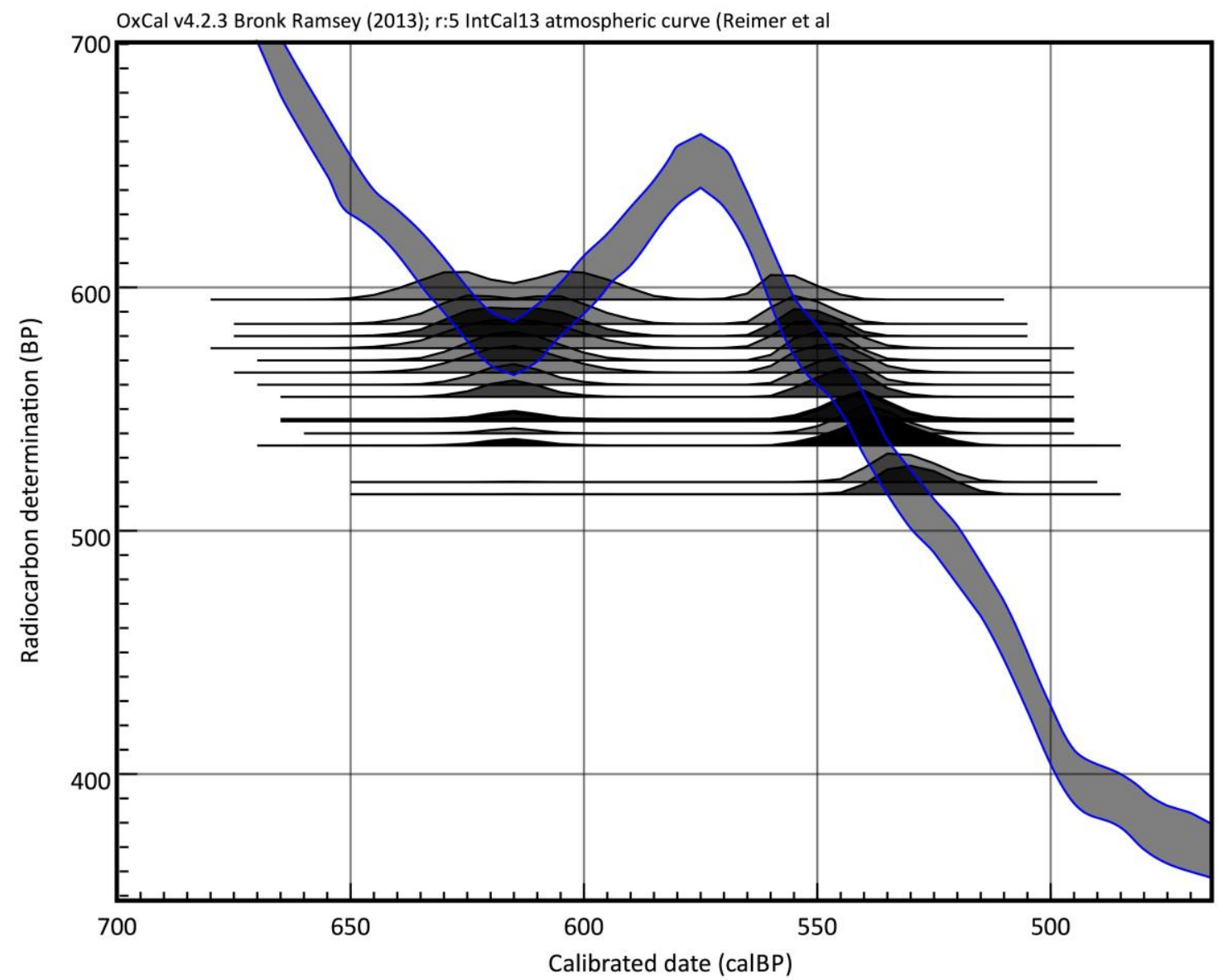

Figure 9. Calibrated probability distributions for 20 early Toyah AMS 14C bison dates. The reversal at ca. 575 cal B.P., resulting in bimodal distributions, causes the calibrated span of time to cover a longer period than is likely. Nonetheless, this is the shortest period of bison exploitation documented in our study.

The brevity of this period of bison exploitation is significant in the culture history of North America. In the regional sequence, the Toyah horizon begins by approximately $650 \mathrm{cal}$ B.P. or A.D. 1300, and lasts as late as A.D. 1700. Native American cultural practices extending to the end of this sequence are difficult to link with earlier prehistoric antecedents because of the influences of Spanish entradas and colonization, not to mention population declines and social disruptions due to European diseases and group displacement practices that started in the early 1500s (Arnn 2012; Kenmotsu and 
Hester 2001). Nonetheless, Toyah culture has typically been defined as exhibiting a technological focus on the exploitation of bison (Johnson 1994; Kenmotsu and Boyd 2012; Prewitt 2012; Ricklis 1994) and artiodactyls generally (Black 1986). Some have noted variation in Toyah subsistence practices (e.g., Dering 2008; Mauldin et al. 2013), including what appears as a decreased emphasis in bison, but temporal controls frequently lack the precision needed to demonstrate whether this variation is temporal or geographic in nature.

Archeologists argue that Toyah is important for our broader anthropological understanding of hunter-gatherer cultural patterns just prior to ethnographically-documented foragers that occupied the region when the Spanish arrived (Collins 1995). Our data suggest that the Toyah horizon may have been characterized by more varied subsistence practices and associated social and technological adaptations than conventional views suggest. From the early A.D. 1500s through the late 1700s, historical groups were recorded pursuing bison across Texas (Arnn 2012; Speth 2004; Wade 2003), and it has been widely presumed that this pattern is an extension of practices that began as early as A.D. 1300 (ca. 650 cal. B.P.). Prior research on the southern Plains has documented widespread trade between Puebloan settlements to the west and Plains groups focusing on bison meat, hide, and other products (Boyd 1997; Creel 1991; Krieger 1946; Prewitt 1982; Speth and Newlander 2012; Spielmann 1991; Vehik 1990, 2002). Considering the sudden appearance of bison and their role in both subsistence and economic patterns, we suggest that early Toyah (ca. A.D. 1300-1420, or 650-530 cal B.P.) can be partly understood as a southern extension of this interregional system. Our findings suggest, however, that middle Toyah sites, those dating after around 530 cal B.P. (A.D. 1420), but pre-dating the reappearance of bison in the mid-1500s, may have maintained an altogether different orientation, with significantly less reliance on bison than previously thought. Although sites with late Toyah material such as the Rush site (41TG346, ca. A.D. 1575; Quigg 1997) or the upper Toyah component at Rowe Valley (41WM437; Prewitt 2012) contain bison and appear to support this threepart model of Toyah chronology, dating resolution is so far lacking to demonstrate the postulated middle Toyah facet. However, the four historic dates in our sample provide partial support for this model. More dates are needed from this late period before this model can be further developed.

\section{DISCUSSIONS AND CONCLUSIONS}

Our record of 61 AMS dates on bison bone recovered from archeological contexts from the southeastern periphery of the Great Plains adds to what is known about the exploitation of a topranked resource starting approximately 6000 years ago. We show that bison were present only occasionally since the Early-Middle Holocene. While our study is generally consistent with previous regional models, it adds important precision to the overall understanding of these periods. It is well known that bison were present in the region prior to $6000 \mathrm{cal}$ B.P., but this part of the record has not been directly dated using the XAD-based protocols we report here. Because the early sequence for bison exploitation is dated primarily by archeological association, in our view it remains imprecise.

In spite of its limitations in terms of geographic and temporal coverage, our record of XADpurified AMS ${ }^{14} \mathrm{C}$ dates on bison offers one of the most precise models for the presence and prehistoric exploitation of this key resource anywhere in North America. In addition to refining local and 
regional chronologies, our findings also contribute to hypotheses about fluctuations in "Plains-like" cultural patterns that depended, in part, on environmental and climatic change and the subsequent exploitation of bison for subsistence and economic purposes. For example, what appears as the sudden onset of bison-related cultural patterns, especially Calf Creek and Toyah, may have been associated with rapid climate change (Mayewski et al. 2004). This important possibility, which deserves further attention, would have significant implications for how archeologists understand the nature and timing of prehistoric culture change. Additionally, the rapid appearance of widespread horizons associated with the Calf Creek and early Toyah periods is ostensibly linked to the sharing of weapons- and processing-related technologies involved with logistically organized bison hunting at these times. Projectile point styles associated with these intervals are among the most widespread postPaleoindian styles in Texas (cf. Prewitt 1995), and may reflect the distances traveled by bison hunters and the kinds of social encounters that occurred as part of these forays.

More than only subsistence practices are implicated as well. Trade patterns beginning by A.D. 1250 (ca. 700 cal B.P.) in the Southern Plains and focused on bison are also well known (e.g., Creel 1991; Speth 2004). Toyah sites commonly show a sharp increase in exotic materials compared with earlier periods (Kibler 2012), suggesting that exchange networks also extended south into Central and southern Texas. Like connections with climate change, this proposition also requires much additional research before these economic processes are fully understood. Future AMS radiocarbon dating work on Toyah sites should be mindful of our evidence suggesting a three-part bison chronology. Sample selection should avoid large carbonized wood fragments susceptible to the old wood effect and focus instead on annuals or perennials. Radiocarbon results should be matched against zooarcheological assemblages indicating the presence or absence of bison.

Our study highlights the research value of adding to the record of XAD-purified AMS dates of bison remains. Adding samples with greater time depth and from additional sites will help improve the bison record and increase its usefulness as a means for understanding larger cultural and environmental processes at the southern extent of the far Southern Plains.

\section{ACKNOWLEDGEMENTS}

Funding for this study was provided by Texas State University and by Mr. Arnold Coldiron. Cinda L. Timperley provided identifications of all bison material from 41HY160, 41HY165, and 41HY188. Thomas R. Hester was the Principal Investigator of the Texas Archeological Society field school at 41ME147, and Harry J. Shafer supervised the work at that site and helped identify and make available the two samples from this site. Permission to include the sample from the Cervenka site was granted by Daniel McGregor of the United States Army Corps of Engineers, Ft. Worth District, and Laura Nightengale of the Texas Archeological Research Laboratory at The University of Texas at Austin helped coordinate that de-accession. Eric Ray and the Museum of the Coastal Bend, Victoria, Texas, granted permission to include two samples from 41VT141. Bill Birmingham was helpful in making available Calf Creek remains from the Coastal Bend area, and Bobby Gray shared information about Calf Creek from Brewster and Jeff Davis counties. The Gault School for Archaeological Research kindly allowed us to include a sample from 41BL323. Derek Hamilton 
provided assistance with the phase model shown in Figure 5. Michael Collins, Elton Prewitt, Raymond Mauldin, and several anonymous reviewers offered helpful comments on earlier drafts of this article. Finally, we deeply appreciate Tim Perttula's editorial guidance.

\section{REFERENCES CITED}

Ambrose, S. H. and L. Norr

1992 On Stable Isotopic Data and Prehistoric Subsistence in the Soconusco Region. Current Anthropology 33:401-404.

Arnn, J. W. III

2012 Land of the Tejas: Native American Identity and Interaction in Texas, A.D. 1300 to 1700. The University of Texas Press, Austin.

Baker, B. W.

1998 Vertebrate Faunal Remains from the 1/4-Inch and 1/8-Inch Screens. In Wilson-Leonard, an 11,000-Year Archeological Record of Hunter-Gatherers in Central Texas. Volume V: Special Studies, edited by M. B. Collins, pp. 1463-1509. Studies in Archeology 31, Texas Archeological Research Laboratory, The University of Texas at Austin and Archeology Studies Program, Report 10, Texas Department of Transportation, Environmental Affairs Division, Austin.

Bamforth, D. B.

1988 Ecology and Human Organization on the Great Plains. Plenum Press, New York.

2011 Origin Stories, Archaeological Evidence, and Post-Clovis Paleoindian Bison Hunting on the Great Plains. American Antiquity 76:24-40.

Bard, E., G. Raisbeck, F. Yiou, and J. Jouzel

2000 Solar Irradiance During the Last 1200 Years Based on Cosmogenic Nuclides. Tellus 52B:985992.

Baugh, S. T.

1986 Late Prehistoric Bison Distributions in Oklahoma. Plains Anthropologist 31:83-96.

Bayliss, A.

2009 Rolling Out Revolution: Using Radiocarbon Dating in Archaeology. Radiocarbon 51(1):123147.

Bement, L. C.

1986 Excavation of the Late Pleistocene Deposits of Bonfire Shelter, 41VV218, Val Verde County, Texas. Archeology Series 1. Texas Archeological Survey, The University of Texas at Austin.

Bement, L. C. and K. J. Buehler

1994 Preliminary Results from the Certain Site: A Late Archaic Bison Kill in Western Oklahoma. Plains Anthropologist 39:173-183. 
Bement, L. C., E. L. Lundelius, Jr., and R. A. Ketcham

2005 Hoax or History: A Bison Skull with Embedded Calf Creek Projectile Point. Plains

Anthropologist 50:221-226.

Bettis, Jr., A. C.

1996 Archaeological Investigations at 41HY188, Hays County, Texas, 1988: A Study of the Archaeological Remains and Lithic Technology. Master's Thesis, Department of Anthropology, The University of Texas at Austin.

Black, S. L.

1986 The Clemente and Herminia Hinojosa Site, 41JW8: A Toyah Horizon Campsite in Southern Texas. Special Report 18. Center for Archaeological Research, University of Texas at San Antonio.

Boyd, D. K.

1997 Caprock Canyonlands Archeology: A Synthesis of the Late Prehistory and History of Lake Alan Henry and the Texas Panhandle-Plains. Reports of Investigations No. 110. Prewitt and Associates, Inc., Austin.

Bozell, J. R., C. R. Falk, and E. Johnson

2011 Native American Use of Animals on the North American Great Plains. In The Subsistence Economies of Indigenous North American Societies: A Handbook, edited by B. D. Smith, pp. 353385. Smithsonian Institution Scholarly Press, Washington, D.C.

Bronk Ramsey, C.

2010 OxCal version 4.17. http://c14.arch.ox.ac.uk/embed.php?file=oxcal.html.

Brown T. A, D. E. Nelson, J. S. Vogel, and J. R. Southon

1988 Improved Collagen Extraction by Modified Longin Method. Radiocarbon 30(2):171-177.

Calame Sr., D., C. Weber, L. Banks, and R. McReynolds

2002 Projectile Points of the Calf Creek Horizon from Frio, Medina, and Uvalde Counties, Southern Texas. La Tierra 29:29-38.

Carlson, K. and L. Bement

2013 Organization of Bison Hunting at the Pleistocene/Holocene Transition on the Plains of North America. Quaternary International 297:93-99.

Carmichael, D.

1986 Archaeological Survey in the Southern Tularosa Basin. Historic and Natural Resources Report No. 3, Environmental Management Office, Directorate of Engineering and Housing, United States Army Air Defense Artillery Center, Fort Bliss, and Publications in Anthropology No. 10, E1 Paso Centennial Museum, University of Texas at E1 Paso. 
Collins, M. B.

1994 Evidence of Early Archaic Occupation. In Human Ecology in the Middle Onion Creek Valley, Hays County, Texas, by R. A. Ricklis and M. B. Collins, pp. 67-100. Studies in Archeology 19. Texas Archeological Research Laboratory, The University of Texas at Austin.

1995 Forty Years of Archeology in Central Texas. Bulletin of the Texas Archeological Society 66:361400.

2004 Archeology in Central Texas. In The Prehistory of Texas, edited by T. K. Perttula, pp. 101-126. Texas A\&M University Press, College Station.

Collins, M. B. (assembler and editor)

1998 Wilson-Leonard: An 11,000-Year Archeological Record in Central Texas. 6 Volumes. Studies in Archeology 31, Texas Archeological Research Laboratory, The University of Texas at Austin, and Archeology Studies Program Report 10, Texas Department of Transportation, Environmental Affairs Division, Austin.

Cooper, J. R.

2008 Bison Hunting and Late Prehistoric Human Subsistence Economies in the Great Plains. Ph.D. Dissertation, Department of Anthropology, Southern Methodist University, Dallas.

Creel, D. G.

1991 Bison Hides in Late Prehistoric Exchange in the Southern Plains. American Antiquity 56:4049.

Denham, T., C. Bronk Ramsey, and J. Specht

2012 Dating the Appearance of Lapita Pottery in the Bismarck Archipelago and its Dispersal to Remote Oceania. Archaeology in Oceania 47:39-46.

Dering, $P$.

2008 Late Prehistoric Subsistence Economy on the Edwards Plateau. Plains Anthropologist 53:59-77.

DeNiro, M.

1985 Postmortem Preservation and Alteration of In Vivo Bone Collagen Isotope Ratios in Relation to Palaeodietary Reconstruction. Nature 317:806-809

Dibble, D. S. and D. H. Lorrain

1968 Bonfire Shelter: A Stratified Bison Kill Site, Val Verde, County, Texas. Miscellaneous Papers No. 1. Texas Memorial Museum. The University of Texas at Austin.

Dickson, D. R.

1970 Excavations at Calf Creek Cave. The Arkansas Archeologist 11:50-82. 
Dillehay, T. D.

1974 Late Quaternary Bison Population Changes on the Southern Plains. Plains Anthropologist 19:180-196.

Duncan, M.

1996 Test Excavations at the Kubic Site, 34KA354. Oklahoma Archeological Survey Newsletter 15:1.

Fenner, J. N.

2007 Prehistoric Hunting on the Range Where the Antelope Play: Archaeological Pronghorn Bed Formation Analysis. Ph.D. Dissertation, Department of Anthropology, University of Wyoming, Laramie.

Frison, G. C.

1991 Prehistoric Hunters of the High Plains. Second edition. Academic Press, New York.

1998 The Northwestern and Northern Plains Archaic. In Archaeology of the Great Plains, edited by W. R. Wood, pp. 140-172. University Press of Kansas, Lawrence.

2004 Survival by Hunting: Prehistoric Human Predators and Animal Prey. University of California Press, Berkeley.

Gray, R. W.

2013 Diagnostic Artifacts of Paleoindian and Early Archaic Cultures in the Eastern Trans-Pecos Region of Texas. In Archeological Explorations of the eastern Trans-Pecos and Big Bend: Collected Papers, Volume 1, edited by P. Dasch and R. J. Mallouf, pp. 1-59. Papers of the Tans-Pecos Archaeological Program 6. Center for Big Bend Studies, Sul Ross State University, Alpine.

Grayson, D. K.

2006 Holocene Bison in the Great Basin, Western USA. The Holocene 16:913-925.

Guthrie, R. D.

1980 Bison and Man in North America. Canadian Journal of Anthropology 1:55-73.

Hester, T. R.

2004 The Prehistory of South Texas. In The Prehistory of Texas, edited by T. K. Perttula, pp. 127151. Texas A\&M University Press, College Station.

2010 An Overview of Excavations at the Eagle Bluff Site and Other Activities of the 2010 Texas Archeological Society Field School. Texas Archeology (Newsletter of the Texas Archeological Society) 54:1, 3-5.

2011 A Summary of the 2011 Texas Archeological Society Field School. Texas Archeology (Newsletter of the Texas Archeological Society) 55:1, 3-11. 
Huebner, J.

1991 Late Prehistoric Bison Populations in Central and Southern Texas. Plains Anthropologist 36:343-358.

Johnson, E.

1987 Vertebrate Remains. In Lubbock Lake: Late Quaternary Studies on the Southern High Plains, edited by E. Johnson, pp. 49-89. Texas A\&M University Press, College Station.

Johnson, E. and V. T. Holliday

1987 Introduction. In Lubbock Lake: Late Quaternary Studies on the Southern High Plains, edited by E. Johnson, pp. 3-13. Texas A\&M University Press, College Station.

Johnson, L., Jr.

1994 The Life and Times of Toyah-Culture Folk: The Buckhollow Encampment, Site 41KM16, Kimble County, Texas. Office of the State Archeologist Report 38. Texas Historical Commission and Texas Department of Transportation, Austin.

Kenmotsu, N. A. and D. K. Boyd (editors)

2012 The Toyah Phase of Central Texas: Late Prehistoric Economic and Social Processes. Texas A\&M University Press, College Station.

Kenmotsu, N. A. and T. R. Hester

2001 Conflict, Migration, and Coalescence: Native American Groups in Texas, A.D. 1530-1878. Bulletin of the Texas Archeological Society 72:1-3.

Kennett, D. J., B. J. Culleton, J. Dexter, S. A. Mensing, and D. H. Thomas

2014 High-Precision AMS 14C Chronology for Gatecliff Shelter, Nevada. Journal of Archaeological Science, http://dx.doi.org/10.1016/j.jas.2014.06.008. Manuscript in press.

Kennett, D. J., B. J. Culleton, B. Voorhies, and J. R. Southon

2011 Bayesian Analysis of High-Precision AMS 14C Date from a Prehistoric Mexican Shellmound. Radiocarbon 53:245-259.

Kibler, K. W.

2012 The Role of Exotic Materials in Toyah Assemblages in a Late Prehistoric Economic and Social System. In The Toyah Phase of Central Texas: Late Prehistoric Economic and Social Processes, edited by N. A. Kenmotsu and D. K. Boyd, pp. 76-89. Texas A\&M University Press, College Station.

Krieger, A. D.

1946 Culture Complexes and Chronology in Northern Texas with Extension of Puebloan Datings to the Mississippi Valley. Publication 4640. The University of Texas, Austin. 
List, R., G. Ceballos, C. Curtin, P. J. P. Gogan, J. Pacheco, and J. Truett

2007 Historic Distribution and Challenges to Bison Recovery in the Northern Chihuahua Desert. Conservation Biology 21:1487-1494.

Lohse, J. C. (editor)

2013 Underwater Archaeology at 41HY147, the Terrace Locality at Spring Lake. Archaeological Studies Report No. 28. Center for Archaeological Studies, Texas State University-San Marcos.

Lohse, J. C., S. L. Black, and L. M. Cholak

2014a Toward an Improved Archaic Radiocarbon Chronology for Central Texas. Bulletin of the Texas Archeological Society 85:251-279.

Lohse, J. C., D. B. Madsen, D. J. Kennett, and B. J. Culleton

2014b Paleoecological Implications of a High-Precision Chronology for Episodic Mid-to-Late Holocene Bison Population Expansions in the Southern Plains, U.S.A. Quaternary Science Reviews, in press.

Lohse, J. C., A. E. Reid, D. M. Yelacic, and C. L. Timperley

2013 Data Recovery and Analysis of the Texas State University Ticket Kiosk at 41HY160, Spring Lake, Hays County, Texas. Archaeological Studies Report No. 32. Center for Archaeological Studies, Texas State University-San Marcos.

Longin, R.

1971 New method of collagen extraction for radiocarbon dating. Nature 230:241-242.

Lynott, M. J.

1979 Prehistoric Bison Populations of North Central Texas. Bulletin of the Texas Archeological Society 50:89-101.

Mann, M. E., Z. Zhang, S. Rutherford, R. S. Bradley, M. K. Hughes, D. Shindell, C. Ammann, G. Faluvegi, and F. Ni

2009 Origins of the Little Ice Age and Medieval Climate Anomaly. Science 326:1256-1259.

Mauldin, R. P., R. J. Hard, C. M. Munoz, J. L. Z. Rice, K. Verostick, D. R. Potter, and N. Dollar

2013 Carbon and nitrogen stable isotope analysis of hunter-gatherers from the Coleman site, a Late Prehistoric cemetery in Central Texas. Journal of Archaeological Science 40:1369-1381.

Mauldin, R., J. Thompson, and L. Kemp

2012 Reconsidering the Role of Bison in the Terminal Late Prehistoric (Toyah) Period of Texas. In The Toyah Phase of Central Texas: Late Prehistoric Economic and Social Processes, edited by N. A. Kenmotsu and D. K. Boyd, pp. 90-110. Texas A\&M University Press, College Station. 
Mayewski, P. A., E. E. Rohling, J. C. Stager, W. Karlén, L. A. Laasch, L. D. Meeker, E. A. Meyerson, F. Gasse, S. van Kreveld, K. Holmgren, J. Lee-Thorp, G. Rosqvist, F. Rack, M. Staubwasser, R. R. Schneider, and E. J. Steig

2004 Holocene Climate Variability. Quaternary Research 62:243-255.

McReynolds, R. L.

2002 Calf Creek Horizon Points from Wilson County, Texas. La Tierra 29:39-44.

Meltzer, D. J.

2006 Folsom: New Archaeological Investigations of a Classic Paleoindian Bison Kill. University of California Press, Berkeley.

Neal, L.

1999 Dating the Kubic Site, 34KA354. Oklahoma Archeological Survey Newsletter 19:1-3.

Neal, L. and M. Duncan

1998 Mid-Holocene Radiocarbon Dates from the Kubic Site (34KA354). Oklahoma Archeological Survey Newsletter 18:2.

O'Brien, M. J. and W. R. Wood

1998 The Prehistory of Missouri. University of Missouri Press, Columbia.

Peter, D., D. Prikryl, O. McCormick, and M.-A. Demunck

1982 Site Excavation Reports: Primary Contract. In Archaeological Investigations at the San Gabriel Reservoir Districts, Central Texas. Volume 1, edited by T. R. Hays, pp. 8-1 to 8-297. Archaeology Program, Institute of Applied Sciences, North Texas State University, Denton.

Prewitt, E. R.

1982 Archeological Investigations at the Loeve-Fox, Loeve and Tombstone Bluff Sites in the Granger Lake District of Central Texas. Volume 4, Archaeological Investigations of the San Gabriel Reservoir Districts, Central Texas. Archaeology Program, Institute of Applied Sciences, North Texas State University, Denton.

1983 Andice: An Early Archaic Dart Point. La Tierra 10:1-10.

1995 Distributions of Typed Project Points in Texas. Bulletin of the Texas Archeological Society 66:83173.

2012 Toyah: Reflections on Evolving Perceptions. In The Toyah Phase of Central Texas: Late Prehistoric Economic and Social Processes, edited by N. A. Kenmotsu and D. K. Boyd, pp. 181203. Texas A\&M University Press, College Station.

Quigg, J. M.

1997 Bison Processing at the Rush Site, 41TG346, and Evidence for Pemmican Production in the Southern Plains. Plains Anthropologist 42:145-161. 
Reimer, P. J., E. Bard, A. Bayliss, J. W. Beck, P. G. Blackwell, C. B. Ramsey, C. E. Buck, H. Cheng, R. L. Edwards, M. Friedrich, P. M. Grootes, T. P. Guilderson, H. Haflidason, I. Hajdas, C. Hatté, T. J. Heaton, D. L. Hoffmann, A. G. Hogg, K. A. Hughen, K. F. Kaiser, B. Kromer, S. W. Manning, M. Niu, R. W. Reimer, D. A. Richards, E. M. Scott, J. R. Southon, R. A. Staff, C. S. M. Turney, and J. van der Plicht

2013 IntCal13 and Marine 13 Radiocarbon Age Calibration Curves, 0-50,000 Years Cal BP. Radiocarbon 55:11869-1887.

Ricklis, R. A.

1988 Archeological Investigations at the McKinzie Site (41NU221), Nueces County, Texas: Description and Contextual Interpretations. Bulletin of the Texas Archeological Society 58:1-76.

1992 The Spread of a Late Prehistoric Bison Hunting Complex: Evidence from the South-Central Coastal Prairie of Texas. Plains Anthropologist 37:261-273.

1994 Toyah Components: Evidence for Occupations in the Project Area during the Latter Part of the Late Prehistoric Period. In Archaic and Late Prehistoric Human Ecology in the Middle Onion Creek Valley, Hays County, Texas, by R. A. Ricklis and M. B. Collins, pp. 207-316. Studies in Archeology 19. Texas Archeological Research Laboratory, The University of Texas at Austin.

Ross, R. E.

1965 The Archaeology of Eagle Cave. Papers of the Texas Archeological Salvage Project 7. The University of Texas at Austin.

Santos G. M., J. R. Southon, K. C. Druffel-Rodriguez, S. Griffin, and M. Mazon

2004 Magnesium Perchlorate as an Alternative Water Trap in AMS Graphite Sample Preparation: A Report on Sample Preparation at the KCCAMS Facility at the University of California, Irvine. Radiocarbon 46(1):165-173.

Sichler, J. A., J. L. Vavrasek, K. D. Hollenbach, and J. C. Lohse

2011 Faunal Remains and Analysis. In Prehistoric Life, Labor, and Residence in Southeast Central Texas: Results of Data Recovery at 41HY163, the Zatopec Site, San Marcos, Texas, edited by J. C. Lohse, pp. 351-386. Archaeological Studies Report No. 18. Center for Archaeological Studies, Texas State University-San Marcos.

Sorrow, W. M., H. J. Shafer, and R. E. Ross

1967 Excavations at Stillhouse Hollow Reservoir. Papers No. 11. Texas Archeological Salvage Project, The University of Texas at Austin.

Speth, J. D.

2004 Life on the Periphery: Economic Change in Late Prehistoric Southeastern New Mexico. Memoirs No. 37. Museum of Anthropology, University of Michigan, Ann Arbor. 
Speth, J. D. and K. Newlander

2012 Plains-Pueblo Interaction: A View from the Middle. In The Toyah Phase of Central Texas: Late Prehistoric Economic and Social Processes, edited by N. A. Kenmotsu and D. K. Boyd, pp. 152180. Texas A\&M University Press, College Station.

Spielmann, K. A. (editor)

1991 Farmers, Hunters, and Colonists: Interaction Between the Southwest and the Southern Plains. University of Arizona Press, Tucson.

Stafford, T. W., Jr., K. Brendel, and R. C. Duhamel

1988 Radiocarbon, 13C and 15N Analysis of Fossil Bone: Removal of Humates with XAD-2 resin. Geochimica et Cosmochimica Acta 52:2257-2267.

Stafford, T. W., Jr., P. E. Hare, L. A. Currie, A. J. T. Jull, and D. Donahue 1991 Accelerator Radiocarbon Dating at the Molecular Level. Journal of Archaeological Science 18:35-72.

Steinhilber, R. and J. Beer

2011 Solar Activity - the Past 1200 Years. PAGES news 19:5-6.

Stites, M. D.

2006 The Calf Creek Complex: Preliminary Research on the Lithic Technology in Kansas. Oklahoma Archeology 54:10-42.

Stuiver, M. and H. A. Polach

1977 Discussion: Reporting of ${ }^{14} \mathrm{C}$ Data. Radiocarbon 19(3):355-363.

Thurmond, J. P. and D. G. Wyckoff

1999 The Calf Creek Horizon in Northwestern Oklahoma. Plains Anthropologist 44:231-250.

Tieszen, L. T., K. J. Reinhard, and D. L. Foreshoe

1997 Appendix C: Stable Isotopes in the Central and Northern Great Plains. In Bioarchaeology of the North Central United Stated: A Volume in the Central and Northern Plains Archeological Overview, edited by D. W. Owsley and J. C. Rose, pp. 329-336. Research Series No. 49. Arkansas Archeological Survey, Fayetteville.

Tzedakis, C.

2003 Timing and Duration of Last Interglacial Conditions in Europe: A Chronicle of Changing Chronology. Quaternary Science Reviews 22:763-768.

Van Geel, B., J. Buurman, and H. T. Waterbolk

1996 Archaeological and Palaeoecological Indications of an Abrupt Climate Change in the Netherlands, and Evidence for Climatological Teleconnections around 2650 BP. Journal of Quaternary Science 11:451-460. 
van Klinken, G. J.

1999 Bone Collagen Quality Indicators for Palaeodietary and Radiocarbon Measurements. Journal of Archaeological Science 26:687-695.

Vehik, S. C.

1990 Late Prehistoric Plains Trade and Economic Specialization. Plains Anthropologist 35:125-145.

2002 Conflict, Trade, and Political Development on the Southern Plains. American Antiquity 67:3764 .

Viau, W. E., K. Gajewski, M. C. Sawada, and P. Fines

2006 Millennial-Scale Temperature Variations in North America During the Holocene. Journal of Geophysical Research, vol. 111. Doi:10.1029/2005JD006031.

Wade, $\mathrm{M}$.

2003 Native Americans of the Edwards Plateau, 1582-1799. The University of Texas Press, Austin.

Walter, R. W.

2013 The Elusive Calf Creek Horizon in the Big Bend. In Archeological Explorations of the eastern Trans-Pecos and Big Bend: Collected Papers, Volume 1, edited by P. Dasch and R. J. Mallouf, pp. 61-70. Papers of the Tans-Pecos Archaeological Program 6. Center for Big Bend Studies, Sul Ross State University, Alpine.

Wanner, H., O. Solomina, M. Grosjean, S. P. Ritz, and M. Jetel

2011 Structure and Origin of Holocene Cold Events. Quaternary Science Reviews 30:3109-3123.

Waters, M. R. and T. W. Stafford

2007 Supporting Online Material for Redefining the Age of Clovis: Implications for the Peopling of the Americas. Science 315:1122-1126.

2014 Redating the Mill Iron Site, Montana: A Reexamination of Goshen Complex Chronology. American Antiquity 79:541-548.

Waters, M. R., T. W. Stafford, H. G. McDonald, C. Gustafson, M. Rasmussen, E. Cappellini, J. V. Olsen, D. Szklarczyk, L. J. Jensen, M. T. P. Gilbert, and E. Willerslev

2011 Pre-Clovis Mastodon Hunting 13,800 Years Ago at the Manis Site, Washington. Science 334:351-353.

Widga, C., J. D. Walker, and L. D. Stockli

2010 Middle Holocene Bison diet and mobility in the eastern Great Plains (USA) based on $\delta^{13} \mathrm{C}$, $\delta^{18} \mathrm{O}$, and ${ }^{87} \mathrm{Sr} /{ }^{86} \mathrm{Sr}$ analyses of tooth enamel carbonate. Quaternary Research 73:449-463.

Wilmshurst, J. M., T. L. Hunt, C. P. Lipo, and A. J. Anderson

2011 High-Precision Radiocarbon Dating Shows Recent and Rapid Initial Human Colonization of East Polynesia. Proceedings of the National Academy of Sciences 108:1815-1820. 
Wyckoff, D. G.

1994 Introduction to the 1991 Bulletin. Bulletin of the Oklahoma Anthropological Society XL:1-8.

1995 A Summary of the Calf Creek Horizon in Oklahoma. Bulletin of the Oklahoma Anthropological Society XLII:179-210.

Wyckoff, D. G., E. Dowd, and D. J. Cranford

2009 Summary Perspectives of Soils and Prehistory along Oklahoma's Cross Timbers. In Geoarchaeology and the Cross Timbers, edited by D. J. Cranford, E. L. Dowd, and D. G. Wyckoff, pp. 75-104. Memoir 13. Oklahoma Anthropological Society, Norman.

Wyckoff, D. G. and L. D. Richens

2010 The Curious Archaic: Calf Creek in Utah? Bulletin of the Oklahoma Anthropological Society LVIII:1-18. 